\title{
Kernel Migration for HTGR Fuels from the Th-U-C-O-N System
}

\author{
T. B. Lindemer \\ R. L. Pearson
}

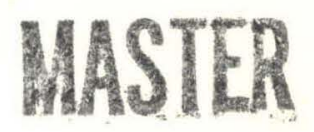

\section{NOTICE}

PORTIONS OF THIS REPORT ARE ILLEGIBLE. It has been reproduced from the best available copy to permit the broadest possible avail-
ability.

\section{OAK RIDGE NATIONAL LABORATORY}




\section{DISCLAIMER}

This report was prepared as an account of work sponsored by an agency of the United States Government. Neither the United States Government nor any agency Thereof, nor any of their employees, makes any warranty, express or implied, or assumes any legal liability or responsibility for the accuracy, completeness, or usefulness of any information, apparatus, product, or process disclosed, or represents that its use would not infringe privately owned rights. Reference herein to any specific commercial product, process, or service by trade name, trademark, manufacturer, or otherwise does not necessarily constitute or imply its endorsement, recommendation, or favoring by the United States Government or any agency thereof. The views and opinions of authors expressed herein do not necessarily state or reflect those of the United States Government or any agency thereof. 


\section{DISCLAIMER}

Portions of this document may be illegible in electronic image products. Images are produced from the best available original document. 
Printed in the United States of America. Available from National Technical Information Service

U.S. Department of Commerce

5285 Port Royal Road, Springfield, Virginia 22161

Price: Printed Copy \$4.50; Microfiche $\$ 2.25$

This report was prepared as an account of work sponsored by the United States Government. Neither the United States nor the Energy Research and Development Administration, nor any of their employees, nor any of their contractors, subcontractors, or their employees, makes any warranty, express or implied, or assumes any legal liability or responsibility for the accuracy, completeness or usefulness of any information, apparatus, product or process disclosed, or represents that its use would not infringe privately owned rights. 


\author{
ORNL/TM-5207 \\ UC-77 - Gas Cooled Reactor Technology \\ Contract No. W-7405-eng-26
}

CHEMICAL TECHNOLOGY DIVISION

KERNEL MIGRATION FOR HTGR FUELS FROM THE Th-U-C-O-N SYSTEM

T. B. Lindemer and R. L. Pearson

Submitted for publication in the Journal of the American Ceramic Society

APRIL 1976

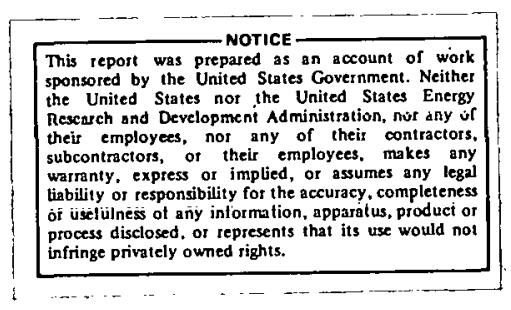

OAK RIDGE NATIONAL IABORATORY

Oak Ridge, Tennessee 37830 operated by UINION CARBIDE CORPORATION for the

ENERGY RESEARCH AND DEVELOPMENT ADMINISTRATION 


\section{THIS PAGE \\ WAS INTENTIONALLY \\ LEFT BLANK}


Table of Contents

$\underline{\text { Page }}$

Abstract $\ldots \ldots \ldots \ldots \ldots \ldots \ldots \ldots \ldots \ldots \ldots \ldots \ldots \ldots \ldots, \quad I$

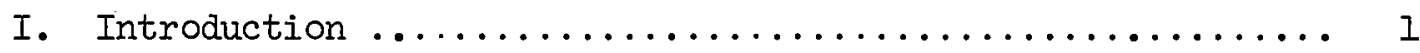

II. General Experimental Methods $\ldots . \ldots \ldots \ldots \ldots \ldots \ldots \ldots$.

III. Determination of Rate-Controlling Mechanisms $\ldots \ldots \ldots \ldots .5$

(1) Dicarbide Fuels $\ldots \ldots \ldots \ldots \ldots \ldots \ldots \ldots \ldots \ldots, 6$

(2) Dioxide Fuels $\ldots \ldots \ldots \ldots \ldots \ldots \ldots \ldots \ldots \ldots \ldots, 9$

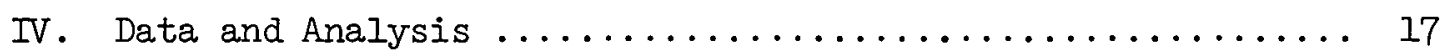

(1) $\mathrm{UO}_{2}+$ Fission-Product Oxides $\ldots \ldots \ldots \ldots \ldots \ldots \ldots \ldots \ldots \ldots \ldots \ldots \ldots$

(2) $\mathrm{UO}_{2}-\mathrm{U}_{2} \mathrm{~N}_{3}$ Solid Solution $\ldots \ldots \ldots \ldots \ldots \ldots \ldots \ldots \ldots \ldots \ldots \ldots \ldots \ldots \ldots$

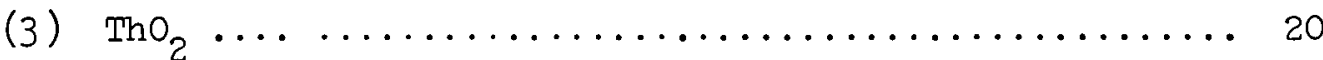

(4) $\mathrm{Th}_{1-z} \mathrm{U}_{\mathrm{z}} \mathrm{O}_{2}+$ Fission-Product Oxides $\ldots \ldots \ldots \ldots \ldots \ldots .24$

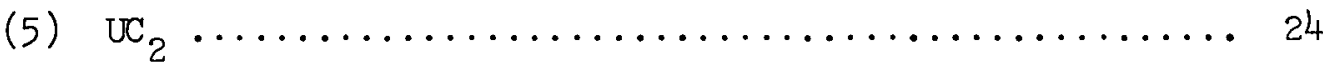

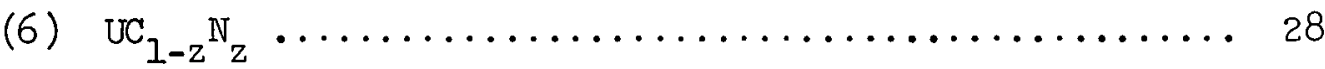

(7) $\mathrm{ThC}_{2} \ldots \ldots \ldots \ldots \ldots \ldots \ldots \ldots \ldots \ldots \ldots \ldots \ldots \ldots \ldots \ldots \ldots \ldots \ldots \ldots \ldots \ldots \ldots, 28$

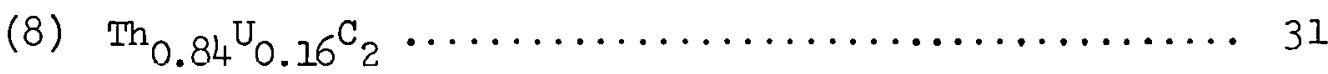

v. Discussion $\ldots \ldots \ldots \ldots \ldots \ldots \ldots \ldots \ldots \ldots \ldots \ldots$, , 31

(1) Carbide Results $\ldots \ldots \ldots \ldots \ldots \ldots \ldots \ldots \ldots \ldots \ldots, 31$

(2) Oxide Results $. . \ldots \ldots \ldots \ldots \ldots \ldots \ldots \ldots \ldots \ldots \ldots, 33$

(3) Application of Data to HTGR Fuel Design ........... 35

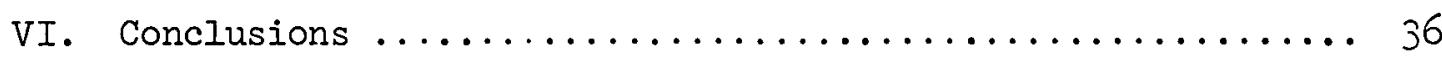

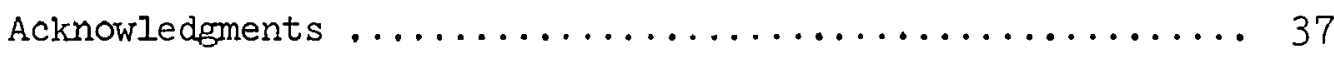

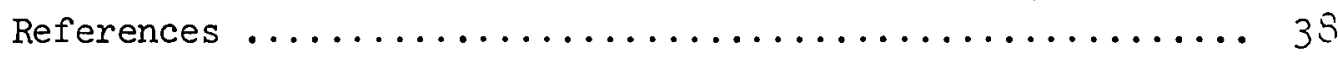

Appendix A. Coated Particle Characteristics ........... 43

Appendix B. Or-iglnal In-Reactor Data Used for KMC

Calculations ...................... 47 
KERNEL MIGRATION FOR HTGR FUELS FROM THE Th-U-C-O-N SYSTEM*

T. B. Lindemer and R. L. Pearson

Abstract

Nuclear fuels for the high-temperature gas-cooled reactor (HTGR) consist of spherical kernels of actinide compounds contained within gastight pyrolytic carbon and SiC. This fuel is subjected to a significant in-reactor temperature gradient that leads to migration of the fuel kernel up the temperature gradient and into the coating layers. This phenomenon has been studied both in the laboratory and in-reactor for fuel kernels from the Th-U-C-O-N system. Application of theory to the analysis of in-reactor migration data indicates that a solid-state diffusion process operating across the kernel controls the migration rate in fissioned $\mathrm{Th}_{0} .84 \mathrm{U}_{0} .16 \mathrm{C}_{2}, \mathrm{UO}_{2}, \mathrm{ThO}_{2}$, and

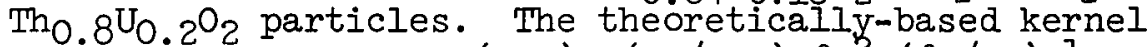
migration coefficient (KMC), $(\mathrm{cm} / \mathrm{sec}){ }^{\circ} \mathrm{K}^{2}\left({ }^{\circ} \mathrm{K} / \mathrm{cm}\right)^{-1}$, is thus used to correlate the data. The in-reactor KMC values were apparently not dependent on the extent of fission, the fission of either $233 \mathrm{U}$ or $235 \mathrm{U}$, or the presence of a $\mathrm{SiC}$ coating layer. Laboratory KMC values were obtained from unirradiated dicarbide particles; these values were in excellent agreement with previously published laboratory KMC data and did not appear to be inconsistent with inreactor dicarbide KMC values. Laboratory KMC values for $\mathrm{ThO}_{2}$ agreed with in-reactor values. The irradiation performance of nitrogen-containing oxide or carbide kernels was no better than that of analogous nitrogen-free compounds.

I. Introduction

Fuel elements for high-temperature gas-cooled reactors (HTGRs) are made from rigid assemblies (fuel rods or compacts) of coated fuel particles distributed appropriately in graphite holders that contain coolant passages and constitute both moderator and core structure. ${ }^{1-3}$ The coated fuel particles consist of small spherical oxide or carbide kernels that

* Research sponsored by the Energy Research and Development Adminiotration under contract with Union Carbide Corporation. 
are each coated with successive layers of pyrolytic carbon ("BISO" particles) and sometimes an intermediate layer of SiC ("TRISO" particles). The pyrolytic carbon layers absorb damaging fission fragments and retain gaseous fission products and their precursurs, while the SiC layer improves the retention of metallic fission products and fuels. ${ }^{4,5}$ These fuels are currently designed to operate from $700^{\circ} \mathrm{C}$ to a nominal maximum of $1550^{\circ} \mathrm{C}$, the latter temperature being sustained for times that are much smaller than the core lifetime.

When a sufficient temperature gradient is imposed across the particle for an adequate time at an appropriately high temperature, one observes a migration of the fuel kernel up the temperature gradient and into the coatings, the so-called "amoeba effect." This phenomenon is one of several that can limit fuel performance and is observed with carbide and oxide kernels of thorium and uranium, as well as with solid solutions of either the carbides or the oxides. The migration rates are sufficiently large to exclude the use of some kernel compounds as U.S. HTGR fuels; therefore, measurement of the migration rates is quite important. Typical microstructures demonstrating the results of this phenomenon have appeared in the literature. ${ }^{6-9}$ This paper will review and apply the previously published theories and analyses that were developed to explain and to properly correlate the experimental duld dul will then present the extensive data obtained in the research and irradiation programs at Oak Ridge National Laboratory.

\section{General Experimental Methods}

In-reactor kernel migration data were obtained from several sources. Kermel migration, $\mathrm{y}$, was obtained from measurements on 40X to $150 \mathrm{X}$ photographs of metallographic cross-sections of irradiated particles contained in fuel rods. The location, $x$, of each particle along the radius of the fuel rod was also measured so that the particle temperature and temperature gradient could be calculated from the temperature equation for the rod. The temperature equations are based on the assumption of uniform internal heat gereration ir the fuel rods. In the case of cylindrical fuel rods, the equation is: 


$$
\mathrm{T}=\mathrm{T}_{\max }-\mathrm{bx^{2 }}
$$

for annular cylindrical fuel rods with no heat flux across the inner surface, the equation is:

$$
T=T_{\max }-b\left(x^{2}-r_{\text {in }}^{2}\left[1+2 \ln \left(x / r_{\text {in }}\right)\right]\right),
$$

where $\mathrm{T}_{\max }$ is the maximum temperature in ${ }^{\circ} \mathrm{K}$ of the fuel rod, $\mathrm{b}$ is a proportionality constant having the units ${ }^{\circ} \mathrm{K} \mathrm{cm}^{-2}$, and $r_{\text {in }}$ is the inner radius in $\mathrm{cm}$ of the annulus. ${ }^{10}$ The term $\mathrm{b}$ for cylinarical rods is more fundamentally equal to the linear heat generation rate of the fuel rod in watts per $\mathrm{cm}$ of length divided by the product ( $4 \pi$ )(thermal conductivity in watts $\mathrm{cm}^{-1}{ }^{\circ} \mathrm{C}^{-1}$ ) (square of the rod radius in $\mathrm{cm}^{2}$ ). Temperature gradients at $x$ values are obtained from the absolute value of the derivative with respect to $\mathrm{x}$ of either Eq. (1) or (2).

Laboratory kernel migration studies were performed by employing another technique on unirradiated particles. Coated particles were bonded. into a $1.27-\mathrm{cm}$-diam. by $0.13-\mathrm{cm}$-thick graphite disc. The graphite disc was made by molding particles into a mixture of 67 wt \% graphite flour and 33 wt $\%$ of a fluid composed of 10 wt \% maleic anhydride in furfural alcohol. The particles were distributed over the midplane of the disc perpendicular to the cylindrical axis. Each disc contained a central row of ten BISO-coated, 475- $\mu \mathrm{m}$-diam., fully-dense $\mathrm{UC}_{2}$ kernels. These kernels, which were oriented parallel to the temperature gradient, served as an internal temperature and temperature gradient standard because the KMC values for $\mathrm{UC}_{2}$ were already known from previous work at the General Atomic Company (GAC). ${ }^{2}$ Approximately 40 particles containing other kernels were randomly distributed throughout the rest of the disc. In order to detect the particle-graphite matrix interface in a radiograph, all the particles were dipped into a concentrated solution of zirconyl chloride and then dried before being placed in the disc. Each disc was subsequently cured in air at $75^{\circ} \mathrm{C}$ for $16 \mathrm{~h}$, buried in graphite flour, and heated in vacuum at $1600^{\circ} \mathrm{C}$ for $4 \mathrm{~h}$. One to three discs were mounted across the $0.95-\mathrm{cm}$-wide gap in the graphite holder (Fig. 1) with a graphite flour--furfural alcohol-maleic anhydride paste. The assembly was cured at $75^{\circ} \mathrm{C}$ in air, and the 
ORNL DWG. 75-14996 RI

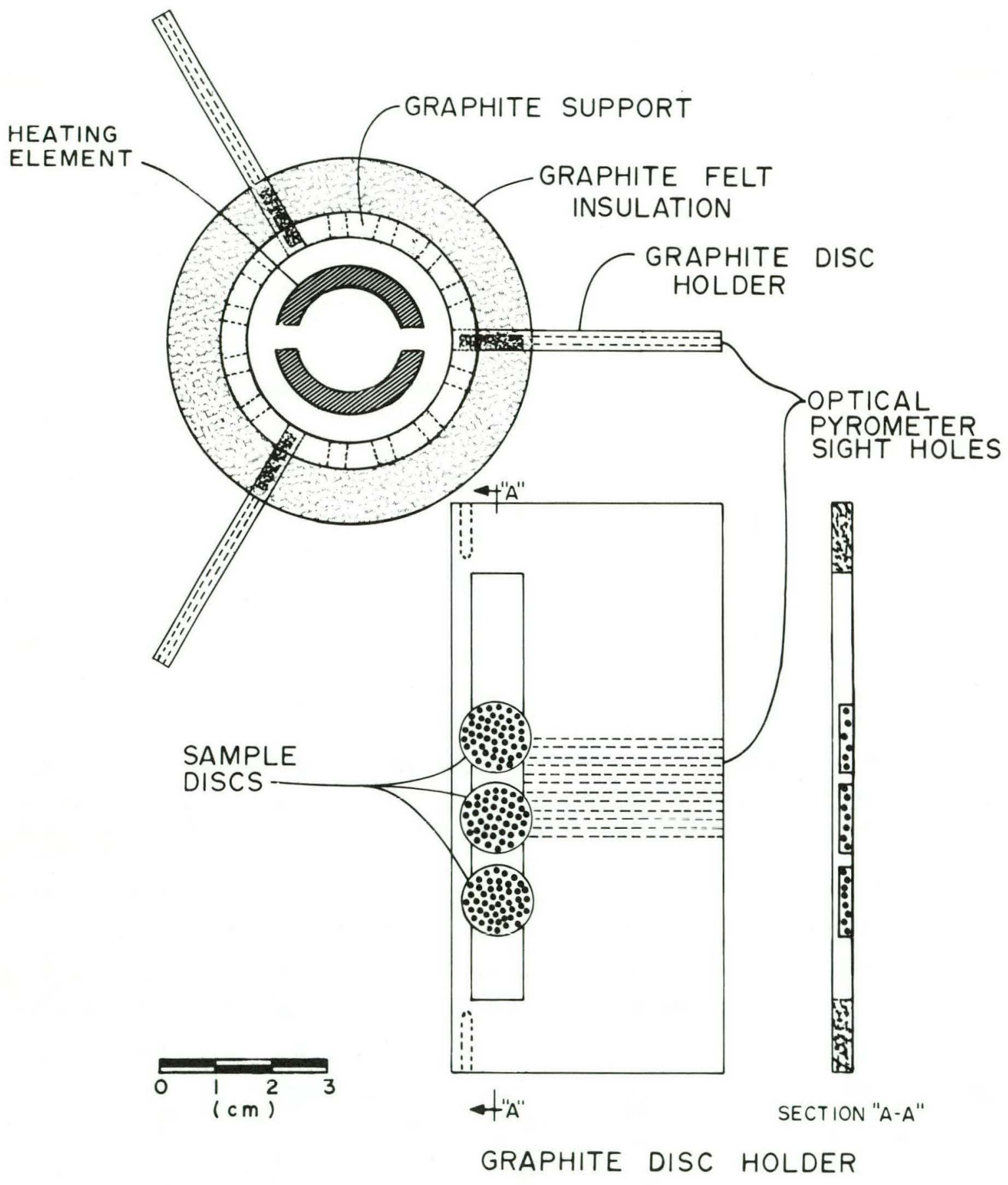

Fig. 1. Apparatus for producing a temperature gradient in sample discs containing coated particles. 
paste was repeatedly added until the gap between the disc and holder was filled with a solid bond of graphite. The holders, mounted as shown in Fig. 1, were heated in a graphite-resistance furnace in which a known temperature and temperature gradient were maintained. Temperatures were read with a disappearing-filament optical pyrometer calibrated against a NBS strip lamp system. Calibrated temperature corrections were also made for the furnace sight window. Other calibrations led to the conclusion that no temperature corrections were necessary for sighting down the 0.185cm-diam. sight holes (Fig. I) or for the graphite emissivity being other than unity at temperature. Several sight holes were drilled to different depths into a disc containing no particles, and measurements showed that the temperature from one side of the disc to the other decreased linearly with distance. It was assumed that the temperature gradient across the kernels was the same as in the disc. ${ }^{7}$ The range of the gradients could be altered from 200 to $575^{\circ} \mathrm{C} / \mathrm{cm}$, depending on the maximum temperature of the run and whether insulation had been placed next to the cold wall inside the furnace. Kemel movement was determined by radiographing the mounted discs before and after heating and then measuring the migration of the hot side of the kernel from the radiographs. Migration data were used only when $\mathrm{y} \geq 5 \mu \mathrm{m}$ in a minimum of $\sim 33 \%$ of the particles that lay above a given temperature; this criterion prevented the generation of spurious $y$ data.

III. Determination of Rate-Controlling Mechanisms

One of three classes of mechanisms - solid-state diffusion, gas-phase diffusion, or a reaction - should control the mass transport rate, and hence the kermel migration rate, in HTGR particles at a given temperature. It is important to determine which of these mechanisms is controlling because each one has a specific theoretically-based parameter to be used for data correlation. In this section, experimental data will be used to identify the controlling mechanism in dicarbide and dioxide fuels. 
(1) Dicarbide Fuels

The migration theory for dicarbides in the Th-U system was historically the first to be developed and was published by Gulden, ${ }^{11}$ whose analysis was based on the principles of irreversible thermodynamics. ${ }^{12}$ Gulden ${ }^{11}$ concluded that the dicarbide migration rate was controlled by the solid-state diffusion of carbon down the temperature gradient and through the dicarbide kernel. The experimental data could be correlated with the aid of the theoretically-based KMC,

$$
\mathrm{KMC}=\mathrm{T}^{2} \frac{\mathrm{dy}}{\mathrm{dt}}\left(\frac{\mathrm{dT}}{\mathrm{dx}}\right)^{-1}=\beta \exp (-\Delta \mathrm{H} / \mathrm{RT})
$$

in which $\mathrm{T}$ is temperature in ${ }^{\circ} \mathrm{K} ; \mathrm{dy} / \mathrm{dt}$ is the observed kemel migration rate in $\mathrm{cm} / \mathrm{sec}$ obtained by dividing the observed migration, $\mathrm{y}$, by the time, $t$, at temperature; $\mathrm{dT} / \mathrm{dx}$ is the temperature gradient in ${ }^{\circ} \mathrm{K} / \mathrm{cm}$ across the particle; and $\mathrm{R}$ is $1.98 \mathrm{cal} \mathrm{mol}^{-1}{ }^{\circ} \mathrm{K}^{-1}$. It should be noted that the $\mathrm{T}^{2}$ term is primarily a scale factor on the KMC; the Arrheniustype temperature effect is equivalent to that for $\Delta H \approx 5,000 \mathrm{cal} / \mathrm{mol}$. A plot of the KMC Vs $T^{-1}$ permits an empirical determination of $\beta$, which is a product containing thermodynamic, geometric, and diffusion terms, and $\Delta \mathrm{H}$, the apparent activation energy in cal/mol of the rate-controlling mechanism. In this case, $\Delta H$ is the enthalpy of carbon self-diffusion in $\mathrm{uC}_{?} \cdot 7,11$

In many irradiations the maximum temperature varied by hundreds of degrees during the course of a run; therefore, it was necessary to calculate an average, $\bar{T}_{\text {max }}$, that could be used to calculate the correct KMC value. Integrating Eq. (3) with respect to time and solving for y leads to the identity

$$
\frac{\beta}{r} \sum_{i}\left[t_{i} T_{i}^{-2}(\Delta \mathrm{T})_{i} \exp \left(-\Delta \mathrm{H} / R T_{i}\right)\right]=\frac{\beta}{r} t \bar{T}_{\max }^{-2} \overline{\Delta T} \exp \left(-\Delta H / R \bar{T}_{\max }\right) .
$$

Here $T_{i}$ is the average experimental $T_{\max }$ during time $t_{i}, \sum_{i} t_{i}=t,(\Delta T)_{i}$ is the temperature difference across the rod of radius $r$ during time $t_{i}$ and is a result of the approximation $(\mathrm{dT} / \mathrm{dx})_{i} \approx(\Delta \mathrm{T})_{i} / r, \overline{\Delta T}=\left[\sum_{i} t_{i}(\Delta \mathrm{T})_{i}\right] / t$, 
and the $\Delta H$ value is that determined from constant-temperature experiments for the particular kernel compound. In most cases, $(\Delta \mathrm{T})_{i}$ is constant and the $\Delta \mathrm{T}$ terms cancel on both sides of $\mathrm{Eq}$. (4). The left-hand side of Eq. (4) was evaluated from the irradiation time-temperature records, and $\overline{\mathrm{T}}_{\max }$ was determined by a Newton-Raphson iteration method. ${ }^{13}$ In-reactor, time-dependent fuel temperatures were calculated by computer codes; ${ }^{14}$ these results were used to evaluate $\vec{T}_{\max }$ and $b$ for calculation of KMC values for each irradiation reported below. It is important to note that the computer-calculated temperatures are uncertain by a minimum of $\pm 100^{\circ} \mathrm{C}$; this often has the net effect of preventing a precise temperature comparison of KMC data from different irradiations.

The theoretically-based techniques developed in Refs. 6 and 15 for establishing the rate-determining kernel migration mechanism can be validated in part with recent dicarbide data. This validation increases the confidence in the use of these theoretical techniques for oxide data correlation. In carbide particles, solid-state diffusion has been estabIished as the mechanism controlling the kernel migration rate by other arguments. $^{11}$ Thus, an analysis of the migration data for $\mathrm{Th}_{0.84} \mathrm{U}_{0.16^{\mathrm{C}} 2}$ by the rate-determining methods given earlier ${ }^{6,15}$ should again indicate control by a solid-state diffusion mechanism. The analytical method 6,15 requires a plot of the migration for each kernel vs the radial location of the particle in the fuel compact, as shown in Fig. 2. These data were obtained from fuel compacts 16 and 18 in the GAC El1-07 irradiation in the 40 MW(e) Pea.sh Rot.tom gas-cooled reactor operated by Philadelphia Electric Company. The average kernel migration behavior as a function of radial location is shown as a solid line in this figure. The theoreticallyderived kernel migration behavior is based on Eq. (3) and is calculated from Eq. (4) of Ref. 15 to give

$$
\frac{y_{x}}{y_{\bar{x}}}=\frac{T_{\bar{x}}^{2}\left(\frac{d T}{d x}\right)_{x} \exp (-\tau \Delta H / R)}{T_{x}^{2}\left(\frac{d T}{d x}\right)_{-}}
$$




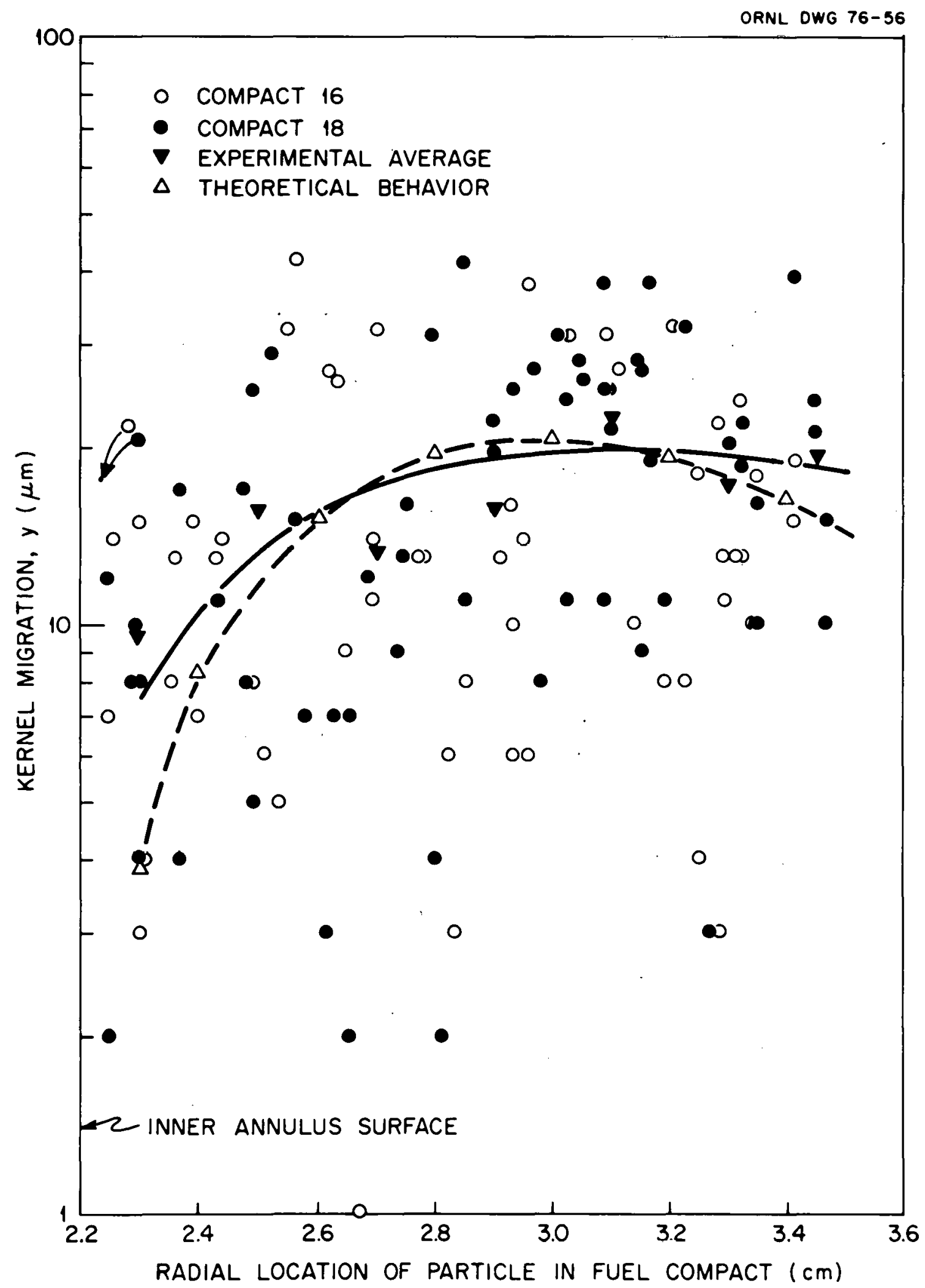

Fig. 2. Th $0.84 \mathrm{U}_{0} .16^{\mathrm{C}}{ }_{2}$ kernel migration in fuel compacts from the Ell-07 irradiation in the Peach Bottom reactor. The theoretical behavior was calculated from Eq. (5) for $\Delta H=76 \mathrm{kcal} / \mathrm{mol}$ and $\bar{x}=2.85 \mathrm{~cm}$. 
where $\bar{x}$ is the radial midpoint in the fuel compact, $x$ ranges from the minimum to the maximum value of the fuel compact radius, and $T=T_{x}^{-1}-T_{\bar{X}}^{-1}$. It is obvious that the ratio in Eq. (5) is 1 when $x=\bar{x}$. For the $\mathrm{Th}_{1-z} \mathrm{U}_{z} \mathrm{C}_{2}$ system, $\Delta \mathrm{H}=76 \mathrm{kcal} / \mathrm{mol}, 7$ and the temperatures and temperature gradients were calculated from Eq. (2) and the applicable $\mathrm{T}_{\max }$ and $\mathrm{b}$ values for the "PBEII-07" compacts listed in Table I. The resulting theoreticallycalculated behavior is shown as the dashed line in Fig. 2; here Eq. (5) has been multiplied by a scale factor of 20 to bring the actual and theoretically calculated curves into compliance for comparison. The agreement of the shapes of the two curves indicates that the migration rate of the dicarbide kemel is indeed controlled by a solid-state diffusion mechanism. More importantly, since $\mathrm{Eq}$. (3) and (5) are valid for solid-state diffusion in both carbide and oxide systems, ${ }^{6}$ this exercise demonstrates the usefulness of the analytical methods developed previously for determining whether or not a solid-state diffusion mechanism controls the rate of kernel migration in dioxide fuels. 6,15

\section{(2) Dioxide Fuels}

The determination of the rate-controlling process in oxide fuels resulted from the theoretical analyses provided by several workers. Flowers and Horsley ${ }^{16}$ presented an initial analysis that considered the effects of gas-phase carbon transport resulting from temperature-dependent gradients of $\mathrm{CO}$ and $\mathrm{CO}_{2}$ pressures in a coated particle. Here the pressures of' these gases are a tunction of' the temperature and pressure dependence of the $\mathrm{CO}-\mathrm{CO}_{2}-\mathrm{C}$ equilibrium, the amount of actinide burnup, the fissionyield spectrum of the fissioning isotope, and the imprecisely known temperature and burnup dependence of the oxidation state of the fuel plus fission-product mixture. ${ }^{16}$ Lindemer and de Nordwall ${ }^{6}$ extended this analysis to include consideration of rate control by either gas-phase CO-CO ${ }_{2}$ diffusion mechanisms, gas-solid and solid-solid reactions, or solid-state diffusion processes in the oxide kernel.

Application of the theoretical developments to the analysis of inreactor migration of $\mathrm{UO}_{2}$ kernels containing $\sim 30 \%$ fission-product oxides resulted in the conclusion that a solid-state diffusion process operating 
Table I. HTGR Particle Irradiation Characteristics

\begin{tabular}{|c|c|c|c|c|c|c|}
\hline $\begin{array}{l}\text { Kernel type } \\
\text { and } \\
\text { irradiation No. }\end{array}$ & $\begin{array}{l}\overline{\mathrm{T}}_{\max } \\
\left({ }^{\circ} \mathrm{K}\right)\end{array}$ & $\begin{array}{c}\mathrm{b} \\
\left({ }^{\circ} \mathrm{K} / \mathrm{cm}\right)\end{array}$ & $\begin{array}{l}\text { Time } \\
\text { (days) }\end{array}$ & $\begin{array}{l}F \perp M A \\
(\%)\end{array}$ & $\begin{array}{l}\text { Range of observed } \\
\text { kermel migration } \\
(\mu \mathrm{m})^{*}\end{array}$ & Footnotes** \\
\hline \multicolumn{7}{|l|}{$\mathrm{WO}_{2}$} \\
\hline $\begin{array}{l}\text { HRB-7-4 } \\
\text { HRB-7-5 } \\
\text { HRB-7-6 } \\
\text { HRB-7-7 } \\
\text { HRB-8-4 } \\
\text { HRB-8-5 } \\
\text { HRB-8-6 } \\
\text { HRB-8-7 }\end{array}$ & $\begin{array}{l}1575 \\
1600 \\
1620 \\
1640 \\
1520 \\
1505 \\
1495 \\
1515\end{array}$ & $\begin{array}{l}710 \\
735 \\
760 \\
780 \\
710 \\
690 \\
670 \\
690\end{array}$ & $\begin{array}{l}184.0 \\
184.0 \\
184.0 \\
184.0 \\
228.0 \\
228.0 \\
228.0 \\
228.0\end{array}$ & $\begin{array}{l}84.68 \\
84.58 \\
84.54 \\
84.57 \\
84.81 \\
84.63 \\
84.56 \\
84.57\end{array}$ & $\begin{array}{c}13-72 \\
20-65 \\
37-63 \\
47-90 \\
8-15 \\
30-82 \\
28-42 \\
50-105\end{array}$ & $\begin{array}{l}a, h, i \\
b, h, i, 1 \\
h, i, 1 \\
h, i \\
h, i \\
b, h, i, 1 \\
h, i, 1 \\
h, i\end{array}$ \\
\hline \multicolumn{7}{|l|}{$\mathrm{ThO}_{2}$} \\
\hline $\begin{array}{l}H-1-10 \\
H-2-11 \\
\text { HRB-3-3A } \\
\text { HRB-4 }\end{array}$ & $\begin{array}{l}2273 \\
2033 \\
1695 \\
1569\end{array}$ & $\begin{array}{r}1488 \\
1600 \\
793 \\
561\end{array}$ & $\begin{array}{r}39.3 \\
39.3 \\
274.0 \\
244.0\end{array}$ & $\begin{array}{r}0.37 \\
0.24 \\
14.00 \\
13.50\end{array}$ & $\begin{array}{c}12-62 \\
4-36 \\
4-9 \\
3-9\end{array}$ & $\begin{array}{l}\mathrm{g} \\
\mathrm{g} \\
\mathrm{g} \\
\mathrm{g}\end{array}$ \\
\hline \multicolumn{7}{|l|}{$\mathrm{Th}_{1-\mathrm{z}_{\mathrm{z}} \mathrm{U}_{2}}$} \\
\hline $\begin{array}{l}\text { HRB-7-12 } \\
\text { HRB-8-12 } \\
\text { HRB-7-8 } \\
\text { HRB-8-8 } \\
\text { H-2-11 } \\
\text { H-1-10 } \\
\text { H-2-10 } \\
\text { H-1-4 } \\
\text { HRB-6-3A } \\
\text { HRB-6-3B } \\
\text { HRB-7-2 } \\
\text { HRB-7-9 } \\
\text { HRB-7-11 } \\
\text { HRB-7-19 } \\
\text { HRB-8-2 } \\
\text { HRB-8-11 } \\
\text { HRB-8-19 } \\
\text { OF1-1-1 } \\
\text { OF1-2-2 } \\
\text { OF1-3-2 } \\
\text { OFI-4-1 } \\
\text { OFI-5-3 } \\
\text { HRB-7-10 } \\
\text { HRB-8-10 }\end{array}$ & $\begin{array}{l}1700 \\
1605 \\
1675 \\
1560 \\
2033 \\
2273 \\
1938 \\
1693 \\
1383 \\
1368 \\
1558 \\
1683 \\
1635 \\
1605 \\
1458 \\
1603 \\
1510 \\
1423 \\
1423 \\
1423 \\
1423 \\
1423 \\
1695 \\
1600\end{array}$ & $\begin{array}{r}810 \\
730 \\
775 \\
695 \\
1600 \\
1488 \\
1512 \\
967 \\
413 \\
413 \\
673 \\
805 \\
820 \\
740 \\
672 \\
740 \\
740 \\
310 \\
310 \\
310 \\
310 \\
310 \\
800 \\
725\end{array}$ & $\begin{array}{r}184.0 \\
228.0 \\
184.0 \\
228.0 \\
39.3 \\
39.3 \\
39.3 \\
97.1 \\
161.0 \\
161.0 \\
184.0 \\
184.0 \\
184.0 \\
184.0 \\
228.0 \\
228.0 \\
228.0 \\
381.0 \\
381.0 \\
381.0 \\
381.0 \\
381.0 \\
184.0 \\
228.0\end{array}$ & $\begin{array}{r}46.32 \\
48.05 \\
33.53 \\
35.83 \\
12.71 \\
8.70 \\
8.78 \\
6.82 \\
24.70 \\
22.80 \\
20.53 \\
23.40 \\
23.40 \\
19.95 \\
22.40 \\
26.21 \\
21.64 \\
19.98 \\
18.44 \\
22.39 \\
19.98 \\
22.68 \\
17.84 \\
20.98\end{array}$ & $\begin{array}{c}7-64 \\
7-42 \\
6-47 \\
5-30 \\
60-200 \\
50-262 \\
16-240 \\
2-43 \\
3-24 \\
7-20 \\
8-25 \\
5-19 \\
14-68 \\
7-22 \\
5-20 \\
10-37 \\
5-18 \\
2-8 \\
2-17 \\
3-10 \\
3-40 \\
2-8 \\
5-38 \\
10-65\end{array}$ & $\begin{array}{l}\text { c, h, i } \\
\text { c, h, i } \\
\text { d, h, i } \\
\text { d, h, i } \\
\text { d, g } \\
\text { e, g } \\
\text { e, g } \\
\text { e, g } \\
\text { e, g } \\
\text { b, e, g } \\
\text { e, h, i } \\
\text { e, h, i, } 1 \\
\text { e, h, i } \\
\text { e, h, i } \\
\text { e, h, i } \\
\text { e, h, i } \\
\text { e, h, i } \\
\text { e, g, k } \\
\text { e, g, k } \\
\text { e, g, k } \\
\text { e, g, k } \\
\text { e, g, k } \\
\text { f, h, i, l } \\
\text { f, h, i, l }\end{array}$ \\
\hline \multicolumn{7}{|l|}{$\operatorname{ThC}_{2}$} \\
\hline $\mathrm{H}-1-9$ & 1873 & 1203 & 39.3 & 0.42 & $50-350$ & $\mathbf{g}$ \\
\hline \multicolumn{7}{|l|}{${ }^{T h} 0.84^{U_{0}} 0.16^{C_{2}}$} \\
\hline $\begin{array}{ll}\text { PBEl1-07 } & \text { C16 } \\
\text { PBEll-07 } & \text { Cl8 }\end{array}$ & $\begin{array}{l}1588 \\
1574\end{array}$ & $\begin{array}{l}30 \\
29\end{array}$ & $\begin{array}{l}701.0 \\
701.0\end{array}$ & $\begin{array}{l}8.95 \\
8.53\end{array}$ & $\begin{array}{l}3-42 \\
7-41\end{array}$ & $\begin{array}{l}h, j \\
h, j\end{array}$ \\
\hline
\end{tabular}

*All migration less than $2 \mu \mathrm{m}$ was ignored.

** The footnotes may be explained as follows:

a. $1 \% \mathrm{UC}_{2}$ added; b. ${ }^{233} \mathrm{U} ; \mathrm{c} \cdot \mathrm{z}=0.50 ; \mathrm{d} . \mathrm{z}=0.33$; e. $z=0.20 ; \mathrm{f} . \mathrm{z}=0.11$;

B. Eq. (1); h. Eq. (2); i. $R_{\text {in }}=0.16 \mathrm{~cm} ; j \cdot R_{\text {in }}=2.2 \mathrm{~cm}, x_{\max }=3.49 \mathrm{~cm}$;

k. nomingl $\bar{T}_{\max }$ and $b ; 1$. TRISO coated. 
across the oxide kernel was controlling the kernel migration rate. 6,15 In addition, the theory demonstrated that $\mathrm{Eq}$. (3) should be used to correlate the $\mathrm{UO}_{2}$ kernel migration data. 6

An analysis of the migration behavior of $\mathrm{ThO}_{2}$ can also be performed. Use of the KMC to correlate the $\mathrm{ThO}_{2}$ data has not been previously substantiated by the method just described because the data from a given fuel rod were always insufficient to determine the rate-controlling mechanism. Therefore, the use of the KMC was assumed for the $\mathrm{ThO}_{2}$ data. However, auxiliary data can be used to demonstrate that other ratecontrolling mechanisms such as a proposed carbon-transporting, $\mathrm{CO}-\mathrm{CO}_{2}$ diffusion mechanism 6,16 does not control the $\mathrm{ThO}_{2}$ migration rate, thus further justifying by default the use of the KMC. The equation for carbon transport by the $\mathrm{CO}-\mathrm{CO}_{2}$ diffusion mechanism has been rigorously derived and is given by Eq. (B27) of Ref. 6 as

$$
y=\frac{\varepsilon^{\prime}}{q^{\prime}} k_{l} t \frac{d T}{d x} \frac{I}{f} \int_{0}^{f} \frac{P_{C O_{1} S_{1}}}{S_{2} S_{3}} d f
$$

in which $\epsilon^{\prime} / q^{\prime}=$ ratio of the observed diffusion coefficient in porous media to that in free space (dimensionless); $f=$ fraction FIMA (Fissions per Initial Metal Atom); $\mathrm{S}_{1}=\mathrm{P}_{\mathrm{CO}}+\mathrm{P}_{\mathrm{CO}_{2}}$ in atm; $\mathrm{S}_{2}=\mathrm{P}_{\mathrm{CO}}+\mathrm{P}_{\mathrm{CO}_{2}}+\mathrm{P}_{\mathrm{g}}+$ $\mathrm{P}_{f g}$ in atm, where $\mathrm{P}_{\mathrm{g}}$ is the pressure of residual coating gases such as $\mathrm{He}$ in the coated particle and $\mathrm{P}_{f g}$ is the pressure of the $\mathrm{Kr}$ and $\mathrm{Xe}$ fissionproduct gases; $\mathrm{S}_{3}=\left(1+2 \mathrm{P}_{\mathrm{CO}_{2}} \mathrm{P}_{\mathrm{CO}}^{-1}\right)^{2}$; and $\mathrm{k}_{\ell}=$ rate constant in $\mathrm{cm}$ of carbon $\mathrm{sec}^{-1}\left({ }^{\circ} \mathrm{C} / \mathrm{cm}\right)^{-1} \mathrm{~atm}^{-1}$ for gas-phase diffusion in the $\mathrm{CO}-\mathrm{CO}_{2}$ system at a given temperature and pressure. The temperature-dependent value of $\mathrm{k}_{\ell}$ can be calculated ${ }^{6}$ from In $\left(\mathrm{k}_{\ell}\right)=-18.04+43,200 / \mathrm{RT}$. Recent measurements of burnup-dependent $\mathrm{P}_{\mathrm{CO}}+\mathrm{P}_{\mathrm{CO}_{2}}$ and $\mathrm{P}_{\mathrm{fg}}$ have been performed ${ }^{17}$ at $1100^{\circ} \mathrm{C} \leq \mathrm{T} \leq 2000^{\circ} \mathrm{C}$ for $\mathrm{BISO}-$ coated $\mathrm{ThO}_{2}$ particles irradiated to $0.03 \leq \mathrm{f} \leq 0.18$. The $\mathrm{P}_{\mathrm{CO}}+\mathrm{P}_{\mathrm{CO}_{2}}$ measurements were converted to the more fundamental oxygen-release-per-fission $(o / f)$ values, which were fitted to give the expression $o / f=(0.594+21.8 f) \exp (-10,900 / \mathrm{RT})$. The $\mathrm{Kr}+\mathrm{Xe}$ release per fission at STP could be expressed as $(\mathrm{Kr}+\mathrm{Xe}) / \mathrm{f}=3.4 \mathrm{f}$ up to $f=0.09$ and as $(\mathrm{Kr}+\mathrm{Xe}) / \mathrm{f}=0.306$ for $\mathrm{f}>0.09$; these results are in close agreement with measurements made by Janvier et al. ${ }^{18}$ It was 
further assumed that $\mathrm{P}_{\mathrm{g}}=\mathrm{P}_{\mathrm{CO}}+\mathrm{P}_{\mathrm{CO}_{2}}=1$ atm for as-coated particles, and that $\varepsilon^{\prime} / q^{\prime}=1$. Consequently, all terms in $E q .(6)$ were given, with in-particle pressures being calculated from the equations for o/f, the thermodynamic equilibrium for the $\mathrm{C}-\mathrm{CO}-\mathrm{CO}_{2}-\mathrm{O}_{2}$ system, $(\mathrm{Kr}+\mathrm{Xe}) / \mathrm{f}$, the ideal-gas law, and an in-particle free volume for the gases that was typically one-half of the original $\mathrm{ThO}_{2}$ volume. Finally, Eq. (6) was couched in units equivalent to those for the solid-state KMC by multiplying both sides of Eq. (6) by $\mathrm{T}^{2} t^{-1}(\mathrm{dT} / \mathrm{dx})^{-1}$. The results of the calculations are shown in Fig. 3. Two distinguishing features are immediately apparent; the calculated KMC increases with burnup at a given temperature and decreases with increasing temperature at a given burnup. The basic reason for this behavior is that the proportion of $\mathrm{CO}_{2}$ increases as $\mathrm{P}_{\mathrm{CO}}+\mathrm{P}_{\mathrm{CO}_{2}}$ increases with temperature at a given burnup. (Similar calculated results based on less-well-known $\mathrm{P}_{\mathrm{CO}}+\mathrm{P}_{\mathrm{CO}_{2}}$ behavior were indicated in Figs. 11-13 of Ref.6.) Comparison of the actual KMC values for $\mathrm{ThO}_{2}$ (to be described later, see Fig. 7) with the data in Fig. 3 clearly shows that the $\mathrm{CO}_{-} \mathrm{CO}_{2}$ gas-phase diffusion mechanism cannot be controlling the $\mathrm{ThO}_{2}$ kernel migration rate.

Recent results for fissioned Th $0.8^{\mathrm{U}_{0}} .2^{\mathrm{O}_{2}}$ can also be analyzed to establish the rate-controlling mechanism for kernel migration. Figure 4 shows kernel migration data obtained from seven different fuel rods in the HRB-7 and -8 irradiations. 19 This figure requires explanation because it is different in some aspects from that for Th $0.84 \mathrm{U}_{0.16} \mathrm{C}_{2}$ (Fig. 2) and that for $\mathrm{UO}_{2}$ plus fission-product oxides in Ref. 15. The migration data are plotted in terms of $y / \bar{y}$, where $\bar{y}$ is the average migration distance observed in a particular fuel rod. This permits data from different fuel rods to be displayed on an equivalent basis even though $\bar{y}$ varied from 10 to $31 \mu \mathrm{m}$. Such a plot is valid as long as the radial particle distribution from rod to rod is equivalent, as was the case with these data. The actual radial dependence of $y / \bar{y}$, as shown in Fig. 4, was obtained by averaging all the $y / \bar{y}$ data within each $0.1-\mathrm{cm}$ increment of the radial position. Theoretical calculations from the equations for the different rate-controlling models could also be performed even though $\mathrm{T}_{\max }$ and $\mathrm{b}$ were different for each rod. It was shown that the shapes of 


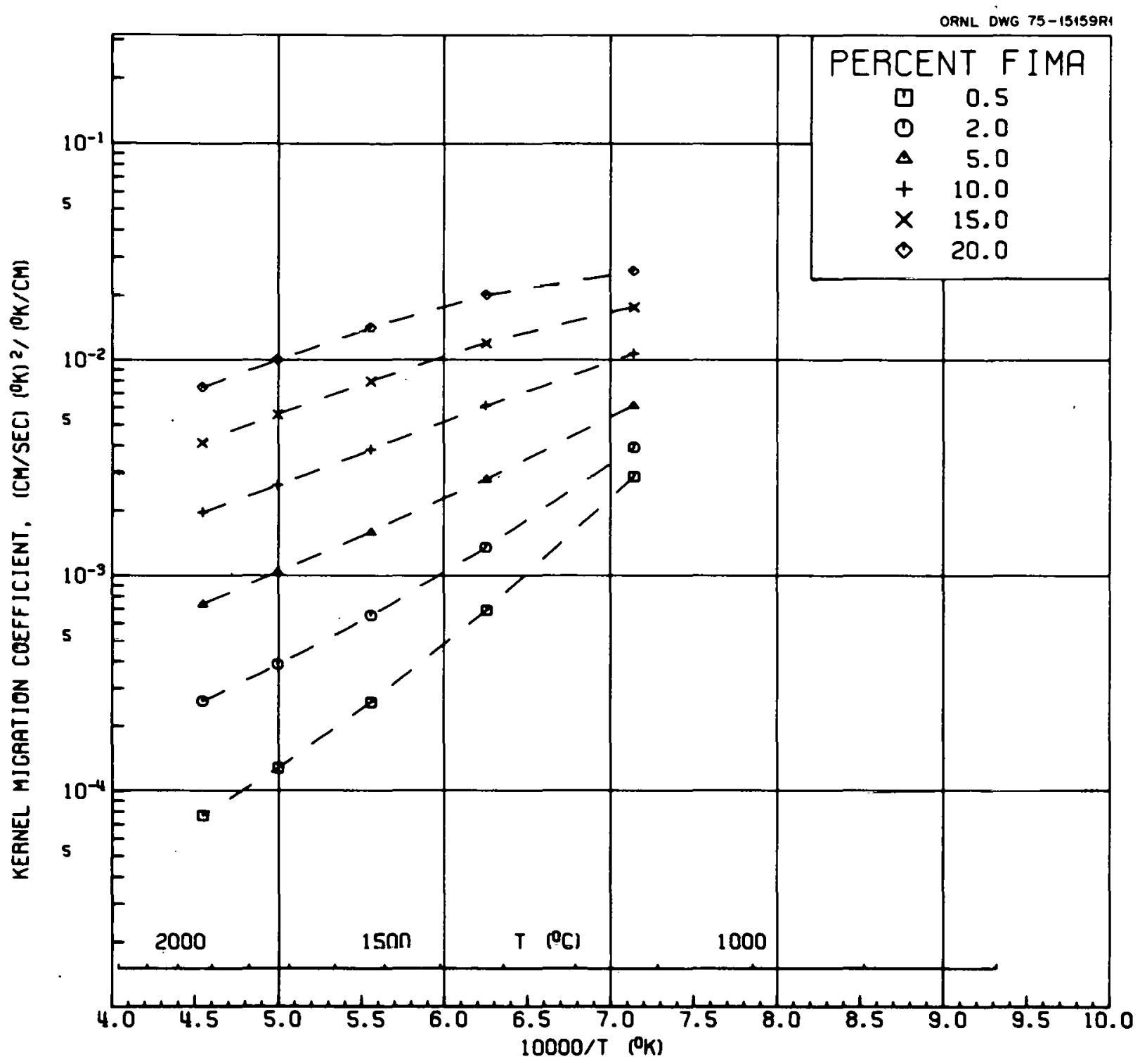

Fig. 3. Calculated $\mathrm{KMC}$ values for in-reactor $\mathrm{ThO}_{2}$ migration controlled by the $\mathrm{CO}-\mathrm{CO}_{2}$ bas-phase diffusion rate. 


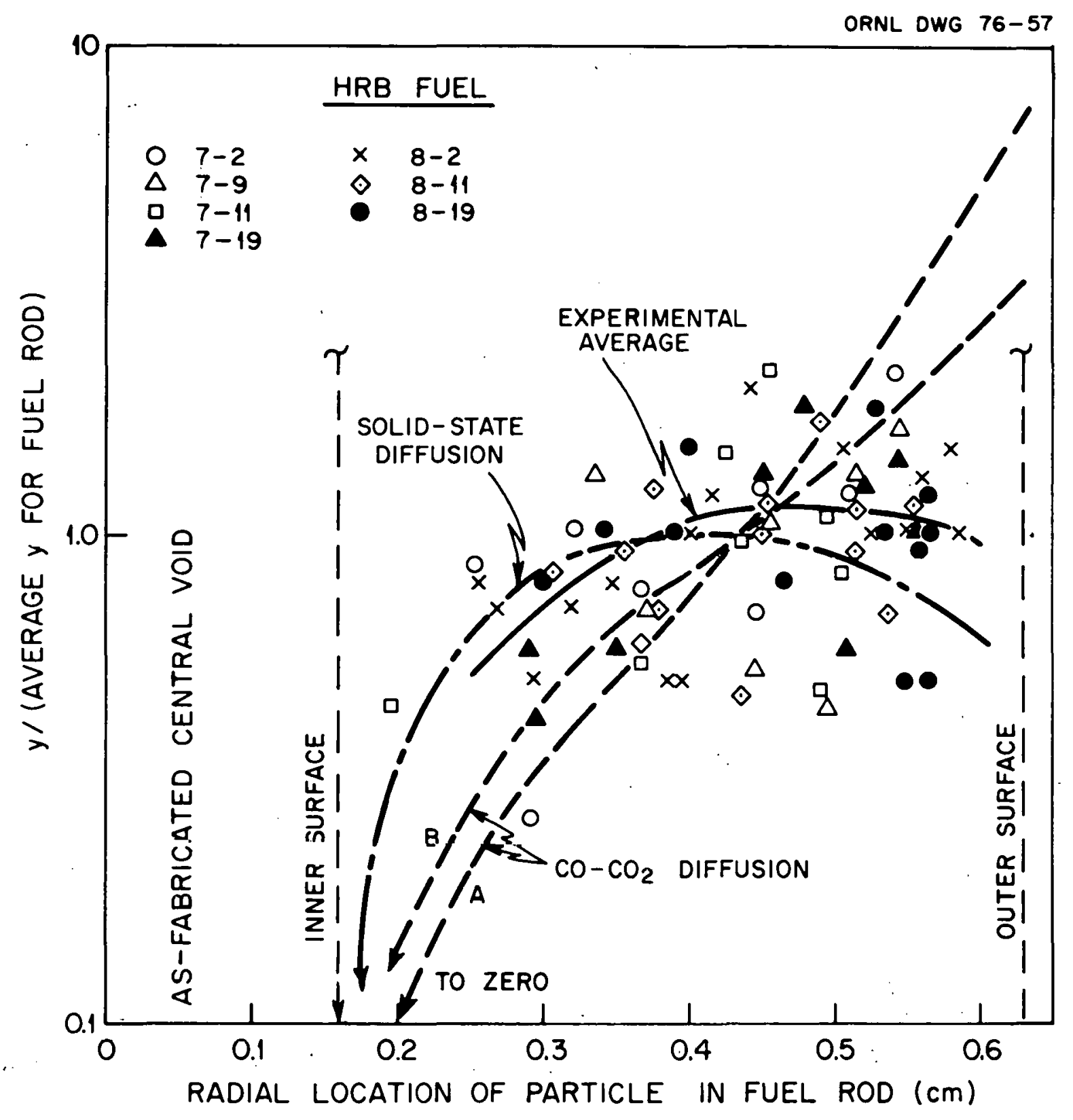

Fig. 4. Normalized Th $0.30^{\mathrm{U}} 0.20_{2} \mathrm{O}_{2}$ kernel migration in fuel rods from the HRB-7 and -8 irradiations. Equation (5) was used to calculate migration behavior controlled by solid-state diffusion through the kernel at $\Delta H=36 \mathrm{kcal} / \mathrm{mol}$. Equation (7) wras used to calculate the migration behavior controlled by $\mathrm{CO}-\mathrm{CO}_{2}$ gas-phase diffusion at $\Delta \mathrm{H}=-43.2 \mathrm{kcal} / \mathrm{mol}$ (A) and $\Delta \mathrm{H}=-20 \mathrm{kcal} / \mathrm{mol}(\mathrm{B})$. 
the theoretical curves calculated from Eq. (5) and from each of Eqs. (1-4) of Ref. 15 were insensitive to $\overline{\mathrm{T}}_{\max }$ and only moderately sensitive to the $\mathrm{b}$ value. Consequently, the $\overline{\mathrm{T}}_{\max }$ and $\mathrm{b}$ values for these seven fuel rods, Table $I$, were each averaged to give $\overline{\mathrm{T}}_{\max }=1587^{\circ} \mathrm{K}$ and $\mathrm{b}=741^{\circ} \mathrm{K} / \mathrm{cm}^{2}$. Also, $\bar{x}=0.435$, the average radial location of all the particles, was used. Equations (2) and (5) were used to calculate the behavior shown in Fig. 4

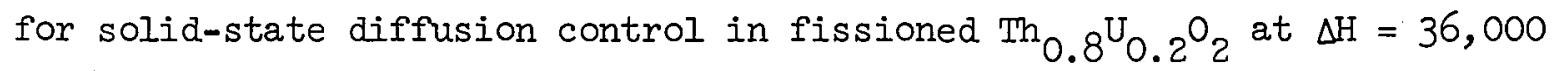
$\mathrm{cal} / \mathrm{mol}$ ( $\mathrm{Table} \mathrm{II}$ ). When $\mathrm{CO}-\mathrm{CO}_{2}$ diffusion controls the migration rate, the following expression for $y / y_{\bar{x}}$ is derived from Eq. (6): 15

$$
\frac{\mathrm{y}}{\mathrm{y}_{\overline{\mathrm{x}}}}=\frac{\left(\frac{d t}{d \mathrm{x}}\right)_{\mathrm{x}} \mathrm{I}_{\mathrm{x}}}{\left(\frac{d t}{d \mathrm{x}}\right)_{\overline{\mathrm{x}}} \mathrm{I}_{\overline{\mathrm{x}}}} \exp (+43,200 \mathrm{\tau} / \mathrm{R})
$$

where $I_{X}$ and $I_{\bar{X}}$ denote the appropriate integral in Eq. (6) and $-43,200$ cal/mol is the $\Delta H$ value for $k_{\ell}$. Equation (7) was used for two different situations. In the first, $I_{\mathrm{X}} / I_{\bar{x}}$ was assumed to be temperatureindependent, and the curve in Fig. 4 for $\Delta H=-43,200 \mathrm{cal} / \mathrm{mol}$ was obtained. In the second, the Arrhenius-type temperature dependence of the $k_{l} \mathrm{I}$ product was assumed to be identical to that for $\mathrm{ThO}_{2}$ at 15 to $20 \%$ FIMA, or $\Delta \mathrm{H}=-20,000 \mathrm{cal} / \mathrm{mol}$. This assumption for $I_{x}$ is reasonable because the o/f and. $\mathrm{Kr}+\mathrm{Xe}$ release data for $\mathrm{Th}_{\mathrm{O}} .8 \mathrm{U}^{\mathrm{U}_{0}} .19^{\mathrm{O}_{2}}$ at $\sim 22 \%$ FTMA and $1100 \leq \mathrm{T} \leq 2000^{\circ} \mathrm{C}$ were consistent with that obtained for fissioned $\mathrm{ThO}_{2}{ }^{17}$ The origin of the value $\Delta \mathrm{H}=-20,000 \mathrm{cal} / \mathrm{mol}$ can be derived. In a coated particle, $\mathrm{P}_{\mathrm{CO}_{2}} \ll \mathrm{P}_{\mathrm{CO}}$ under most of the conditions of interest here; thus, in Eq. (6), $S_{3}^{2}=1$ and $S_{1}=P_{C O}$. Also, $P_{f g}>P_{C O}$ and $S_{2}$ does not reflect an appreciable Arrhenius-type temperature dependence, effectively leaving $\mathrm{P}_{\mathrm{CO}}^{2}$ in the numerator of the integral as the only such temperaturedependent term. The $P_{C O}$ value is calculated from the o/f value; thus the $\mathrm{k}_{\ell} \mathrm{I}$ product has an effective $\Delta \mathrm{H}=-43,200+2(10,900) \approx-20,000 \mathrm{cal} / \mathrm{mol}$. Equation (7) was used to calculate the curve for $\Delta \mathrm{H}=-20,000 \mathrm{cal} / \mathrm{mol}$ in Fig. 4. The experimental average behavior agrees much more closely with the calculated behavior of the solid-state mechanism than with the calculated behavior of the $\mathrm{CO}_{-} \mathrm{CO}_{2}$ diffusion mechanism. Finally, consider the calculated $x-y$ behavior resulting from rate control by a reaction which 
Table II. Coefficients for Equation (8)

\begin{tabular}{|c|c|c|c|}
\hline & $\rho_{2}^{\alpha}$ & $\alpha_{1}$ & $\Delta \mathrm{H}$ \\
\hline Kernel & $\left(\log \left[\mathrm{cm}^{2} T^{2}(d T / d x)^{-1}\right]\right)$ & {$\left[\Delta \mathrm{H}(2.303 R)^{-1}\right]$} & $(\mathrm{kcal} / \mathrm{mol})$ \\
\hline
\end{tabular}

Laboratory Data

$\mathrm{UO}_{1.65^{\mathrm{N}} 0.25}$

$-2.49 \pm 0.47^{* *}$

$5,280 \pm 890^{* *} \quad 24.3$

$\mathrm{ThO}_{2}$

$-0.31 \pm 0.61$

$10,200 \pm 1280 \quad 47.1$

$\operatorname{ThC}_{2}$

$3.51 \pm 0.27$

$15,600 \pm 530 \quad 71.8$

$\mathrm{UC}_{2}$

$1.96 \pm 0.51$

$13,100 \pm 1030 \quad 60.4$

In-Reactor Data

$\begin{array}{llll}\mathrm{UO}_{2}^{*} & -2.77 \pm 0.43 & 4,800 \pm 580 & 22.1 \\ \mathrm{Th}_{0.8} \mathrm{U}_{0.2} \mathrm{O}_{2}^{*} & -0.82 \pm 0.28 & 7,830 \pm 420 & 36.0 \\ \mathrm{ThO}_{2}^{*} & -0.85 \pm 0.47 & 8.900 \pm 790 & 41.0\end{array}$

*Final fission-product oxide "concentrations approximately equal to percent FIMA, Table..I.

** One standard deviation. 
has been given in Fig. I of Ref. 15. Such control always indicates that $\mathrm{y}$ decreases as $\mathrm{x}$ increases simply because the reaction rate decreases with temperature; the experimental average behavior in Fig. 4 does not indicate such behavior. Thus, a solid-state diffusion process operating across the kernel appears to control the rate of kernel migration in the fissioned Th $0.8^{\mathrm{U}_{0}} \mathrm{O}_{2}$ particle.

IV. Data and Analysis

Many sources of data are used to calculate KMC values. The first U.S. in-reactor KIMC data for oxide kernels were obtained at ORNL in mid1973 from the $\mathrm{H}-1$ and $\mathrm{H}-2$ irradiations. ${ }^{20,21}$ subsequent irradiations at ORNL and GAC have added to the in-reactor KMC for oxide and carbide kermels. The migration results, the temperature conditions, and the particle and kernel dimensional data are available for each particle measured at ORNL to date. ${ }^{22,23}$ In addition, comprehensive reports for most of the irradiations are also available (see the list of references). All oxide and carbide kernels were $\sim 97 \%$ of theoretical density and were BISO-coated unless specified as TRISO-coated. The uranium contents were 93\% enriched ${ }^{235} \mathrm{U}$ unless stipulated otherwise. Kernel migration measurements were always obtained from the penetration of the higher-temperature kernel interface into the coating layers; the observed range of migration values for each irradiation is given in Table $I$.

Unirradiated, as-coated particles were also used in laboratory experiments to determine KIMC values; such values are called "laboratory data" in this report. The least-squares fit of the KMC data to the equation

$$
\log _{10}(\mathrm{KMC})=\alpha-\alpha_{1} \mathrm{~T}^{-1}
$$

was performed for specific kernel compositions. The values of $\alpha=\log _{10} \beta$, $\alpha_{1}=\Delta H(2.303 R)^{-1}$, and their standard deviations ${ }^{24}$ are given in Table II for the cases where KMC data existed over a temperature range sufficient to calculate a meaningful $\Delta H$ value. Confidence limits were computed for the KMC data such that one is $90 \%$ confident that a single future determination of a KMC value will lic between the linuits. 24 
(1) $\mathrm{UO}_{2}+$ Fission-Product Oxides

Migration measurements are available from four irradiations. Inreactor data for 69 particles from the H-l-2 irradiation ${ }^{20}$ to $30 \%$ FIMA have been reported previously; ${ }^{15}$ a least-squares fit of the H-l-2 data is shown in Fig. 5. Also shown are recent data at 85\% FIMA from the HRB-7 and -8 irradiations. ${ }^{19}$ The fission products $\mathrm{Zr}, \mathrm{Ba}, \mathrm{Sr}, \mathrm{Y}, \mathrm{La}$, and the rare earths form oxides and collectively yield $\sim 1$ mol of oxides per mol of $\mathrm{UO}_{2}$ that fissioned. Thus, burnups of 30 to $85 \%$ FIMA result in similar percentages of fission-product oxides, the balance of the kernel oxide being $\mathrm{UO}_{2}$. The $\mathrm{KMC}$ values are obviously for kernels of this composition. TRISO-coated particles were used in HRB-7-5 and -6 , and in HRB-8-5 and -6 ; $233 \mathrm{UO}_{2}$ kernels were used in HRB-7-5 and HRB-8-5 particles. GAC has also reported TRISO-particle KMC data that agree with the present data. ${ }^{25}$ Collectively, these results apparently do not indicate a significant difference in KMC values originating from BISO-vs-TRISO particles, ${ }^{233} \mathrm{UO}_{2}$ vs ${ }^{235} \mathrm{UO}_{2}$ kernels, or burnup. The H-I-2, HRB-7, and HRB-8 data were thus fitted to Eq. (8) to give the parameters shown in Table II.

Several laboratory experiments on as-coated $\mathrm{UO}_{2}$ particles from 1200 to $1900^{\circ} \mathrm{C}$ failed to produce kernel migration at times and temperature conditions that should have been sufficient to promote observable migration.

(2) $\mathrm{UO}_{2}-\mathrm{U}_{2} \mathrm{~N}_{3}$ Solid Solution

The solid solution of $\mathrm{UO}_{2}$ and $\mathrm{U}_{2} \mathrm{~N}_{3}$ was investigated as a possible HTGR fuel. At HTGR temperatures, extensive amounts of $\mathrm{U}_{2} \mathrm{~N}_{3}$ can dissolve in the face-centered-cubic $\mathrm{UO}_{2}$ lattice. 26,27 In a pyrocarbon-coated HTGR particle this establishes the equilibriun $\left[\mathrm{U}_{2} \mathrm{~N}_{3}\right]+4 \mathrm{CO} 2\left[\mathrm{UO}_{2}\right]+$ $1.5 \mathrm{~N}_{2}+4 \mathrm{C}$, where the brackets indicate the single-phase solid solution. It was postulated from the form of the equilibrium constant that operation of this equilibrium during burnup would result in $\mathrm{CO}$ pressures $\left(\mathrm{P}_{\mathrm{CO}}\right)$ substantially lower than those generated in fissioning $\mathrm{UO}_{2}$ particles. 28 Laboratory KMC values obtained for as-coated $\mathrm{UO}_{1.65} \mathrm{~N}_{0.25}$ are shown in Fig. 5; at the indicated temperatures, in-particle $\mathrm{P}_{\mathrm{CO}}$ and $\mathrm{P}_{\mathrm{N}_{2}}$ were 


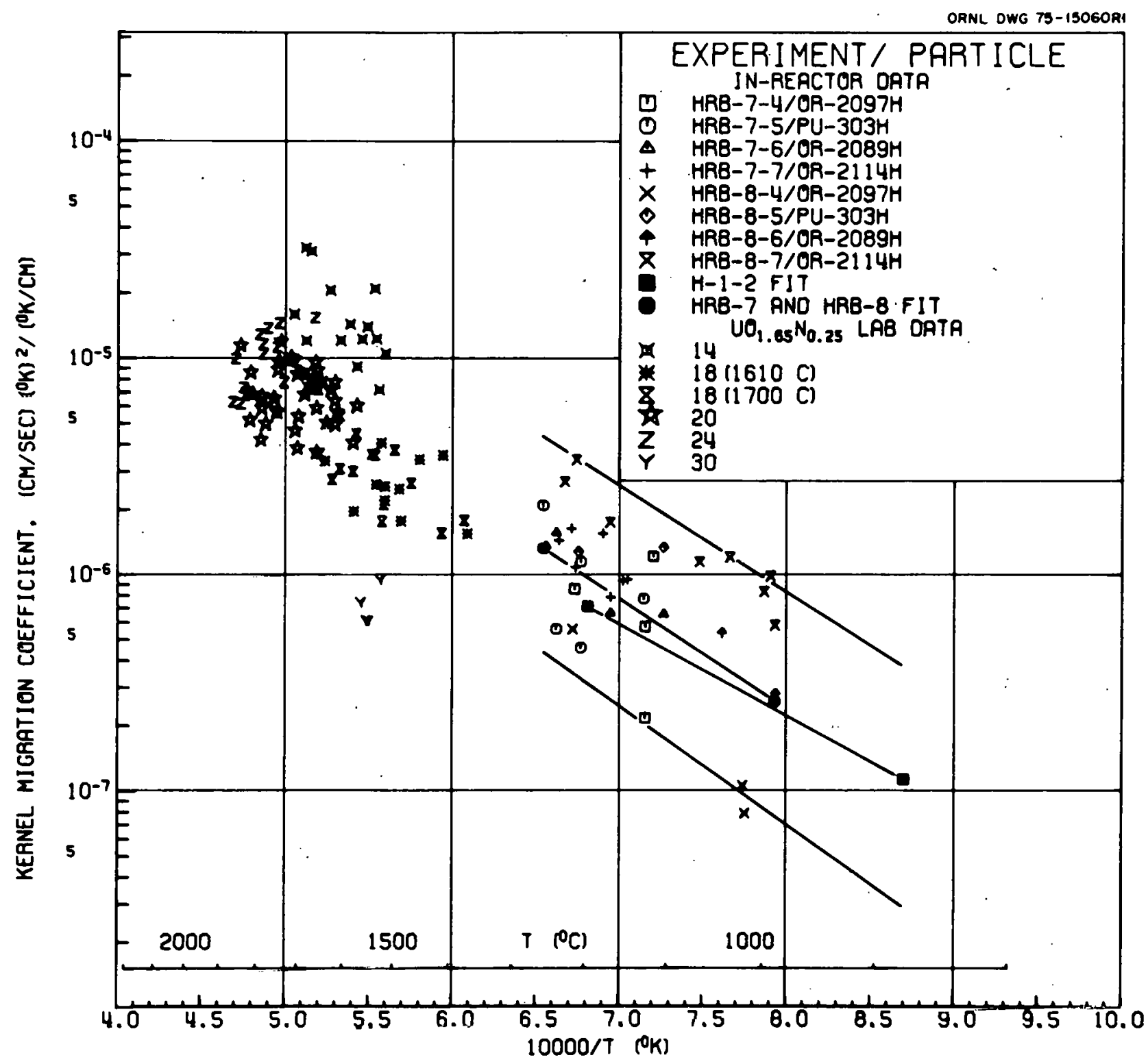

Fig. 5. Laboratory $\mathrm{KMC}$ values for as-coated $\mathrm{UO}_{1.65} \mathrm{~N}_{0.25}$ (particle batch A6590-55P) and in-reactor KMC values for $\mathrm{UO}_{2}$ plus fission-product oxides irradiated either to 85\% FIMA or to 30\% FIMA (H-1-2). The $90 \%$ contidence limits for irradiated $\mathrm{UO}_{2}$ are for all the KMC data from $\mathrm{H}-1-2$, HRR-7, and HRB-8. Coated-particle batch numbers (such as "OR-2097H") given in this and subsequent figure legends can be used to identify the specific characteristics of coated particles described in the references. 
each $~ 0.5 \mathrm{~atm} .^{28}$ Applicability of the KMC is assumed here so that a comparison could be made with the in-reactor $\mathrm{KMC}$ values for $\mathrm{UO}_{2}$. The parameters for the least-squares fit of Eq. (8) are given in Table II for the laboratory data. It appears from Fig. 5 that the migration behavior in the two systems is comparable. Typical in-reactor behavior 19 at $80 \%$ FIMA of a kernel with the initial composition $\mathrm{UO}_{1.50} \mathrm{NO}_{0.38}$ is shown in Fig. 6; at this burnup, $P_{\mathrm{CO}}$ and $P_{\mathbb{N}_{2}}$ were calculated to be $\sim 0.5$ and $\sim 350 \mathrm{~atm}$, respectively. Penetration of the kernel material into the coating layers was randomly oriented toward the direction of the temperature gradient. However, the extent of migration was approximately that expected for a $\mathrm{UO}_{2}$ kernel for the particular $\mathrm{T}, \mathrm{dT} / \mathrm{dx}$, and $t$ conditions. This is again consistent with the KMC values in Fig. 5 and indicates that the migration properties of the fissioned $\mathrm{UO}_{2}-\mathrm{U}_{2} \mathrm{~N}_{3}$ solid-solution kernel are not an improvement over those for fissioned $\mathrm{UO}_{2}$ kernels.

\section{(3) $\mathrm{ThO}_{2}$}

In-reactor KMC data obtained from several irradiations are shown in Fig. 7. Burnup values ranged from 0.24 to $0.35 \%$ FIMA in the $\mathrm{H}-1$ and $\mathrm{H}-2$ irradiations, ${ }^{20,} 22$ to $14.0 \%$ FIMA in the HRB-3 irradiation, 29 and to $13.5 \%$ FTMA in the HRB-4 irradiation. 30 No apparent burnup effect was evident in the KMC values. It should be noted that the high-burnup ThO 2 kernels contained $\sim 2.5$ to $3.0 \%$ of bred-in $U ;^{6,17}$ Tho 2 particles in the HTGR would contain similar amounts.

The laboratory KMC data obtained on as-coated $\mathrm{ThO}_{2}$ kernels agree with the in-reactor data (see Fig. 7 and Table II). A photomicrograph of an as-coated $\mathrm{ThO}_{2}$ kernel after migration (see Fig. 8) exhibits the cold-side graphitic deposit typically seen behind the kernel in in-reactor specimens. 20,29,31 Laboratory KMC data were also obtained from 1310 to $1480^{\circ} \mathrm{C}$ by GAC on previously irradiated $\mathrm{ThO}_{2}$ particles; $3^{2}$ these data agree with those in Fig. 7 .

The laboratory migration data for $\mathrm{ThO}_{2}$ were also analyzed to demonstrate a linear $y-t$ dependence. Seven particles heated at 1825 to $1045^{\circ} \mathrm{C}$ in one' specimen at $\mathrm{dT} / \mathrm{dx}=280^{\circ} \mathrm{C} / \mathrm{cm}$ migrated an average of $4.4,6.7,10.1$, 


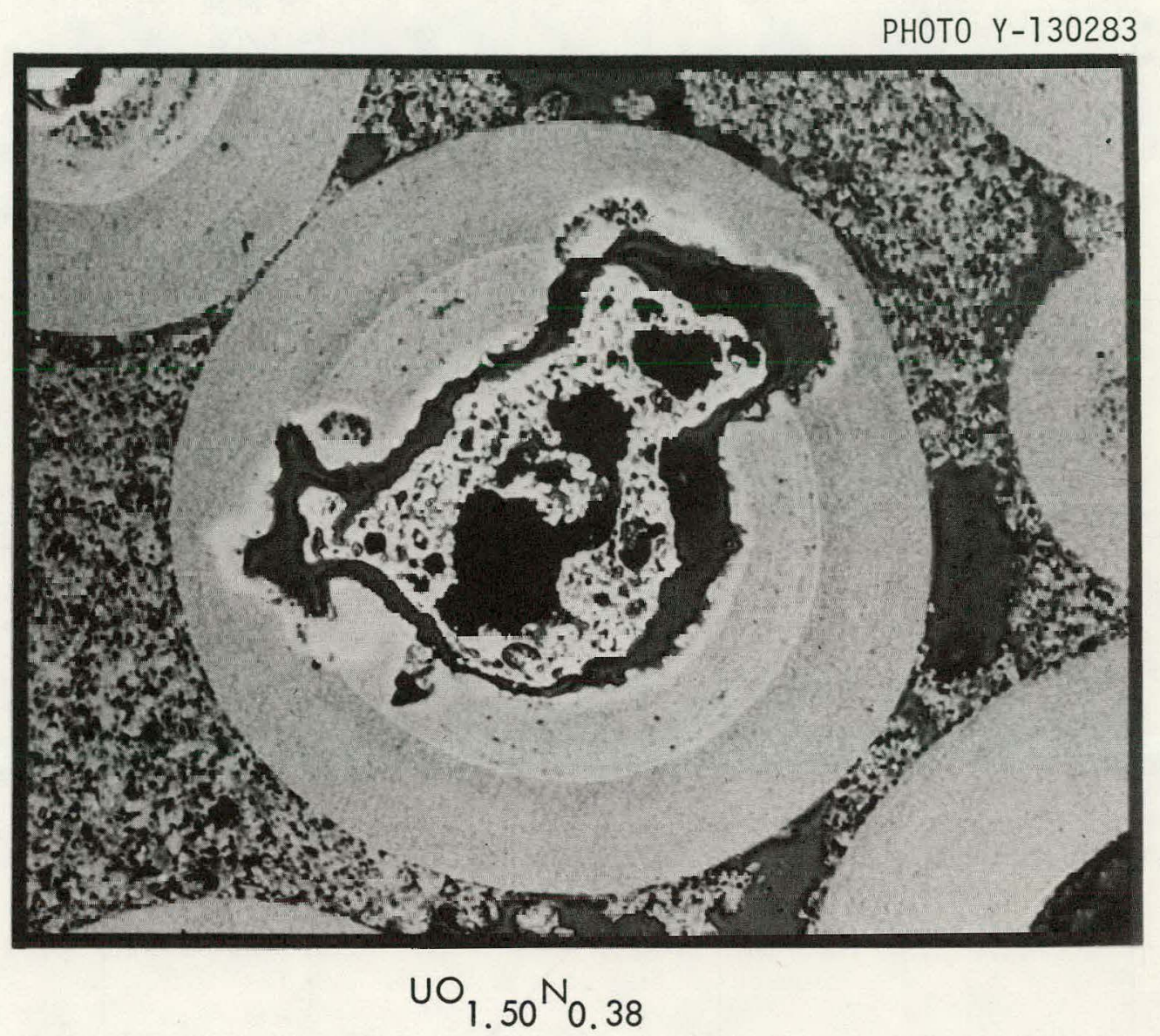

Fig. 6. Kernel migration in fissioned $\mathrm{UO}_{1.50^{\mathrm{N}} \mathrm{O} .38}$ at $\sim 1150^{\circ} \mathrm{C}$, $\sim 650^{\circ} \mathrm{C} / \mathrm{cm}$, and $\sim 80 \%$ FTMA in the HRB-7 irradiation. 


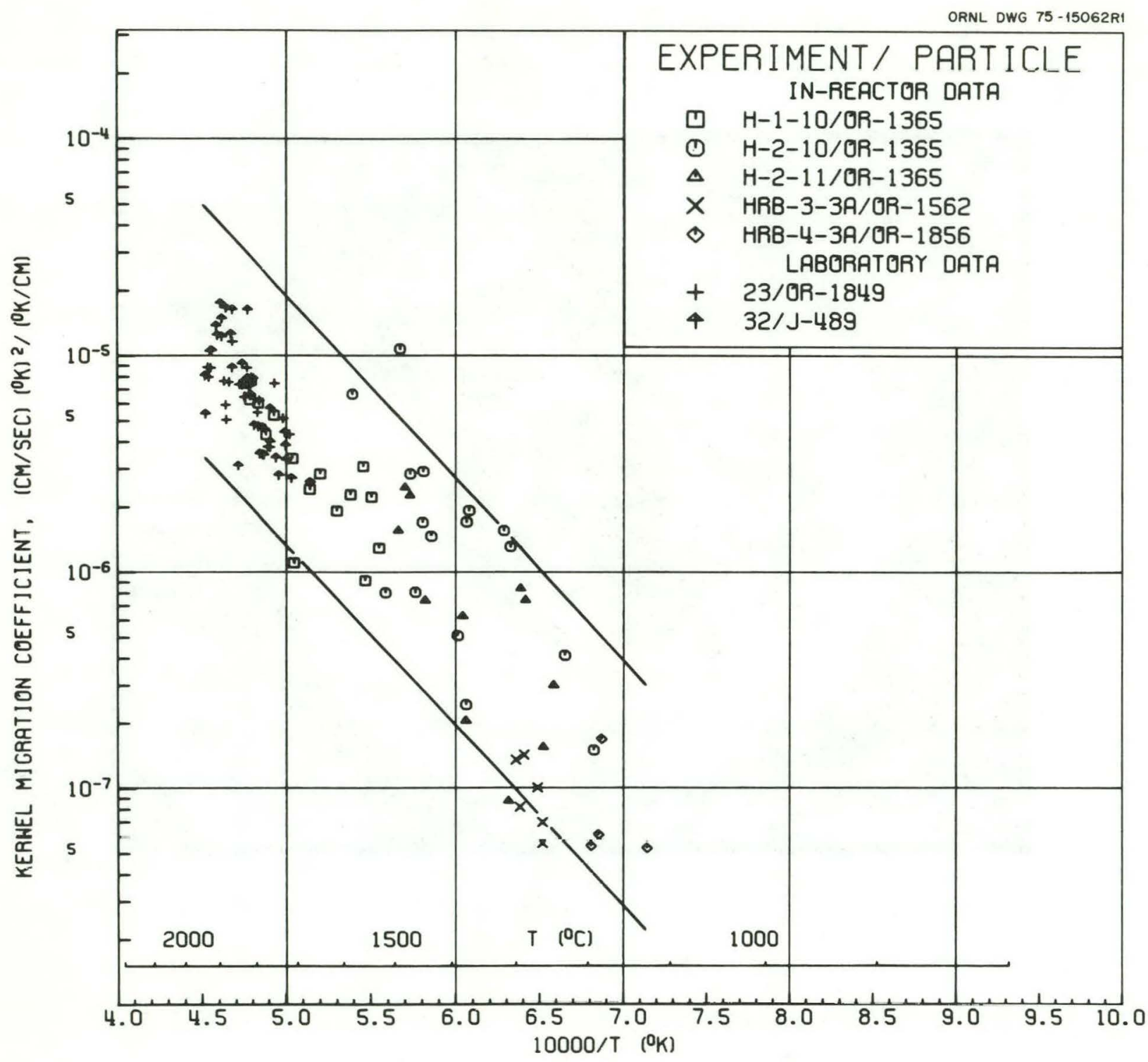

Fig. 7. Laboratory KMC values for as-coated $\mathrm{ThO}_{2}$ and in-reactor KMC values for $\mathrm{ThO}_{\mathrm{C}}$ irradiated from 0.24 to $14.0 \%$ FIMA. The $90 \%$ confidence limits are for the in-reactor data. 


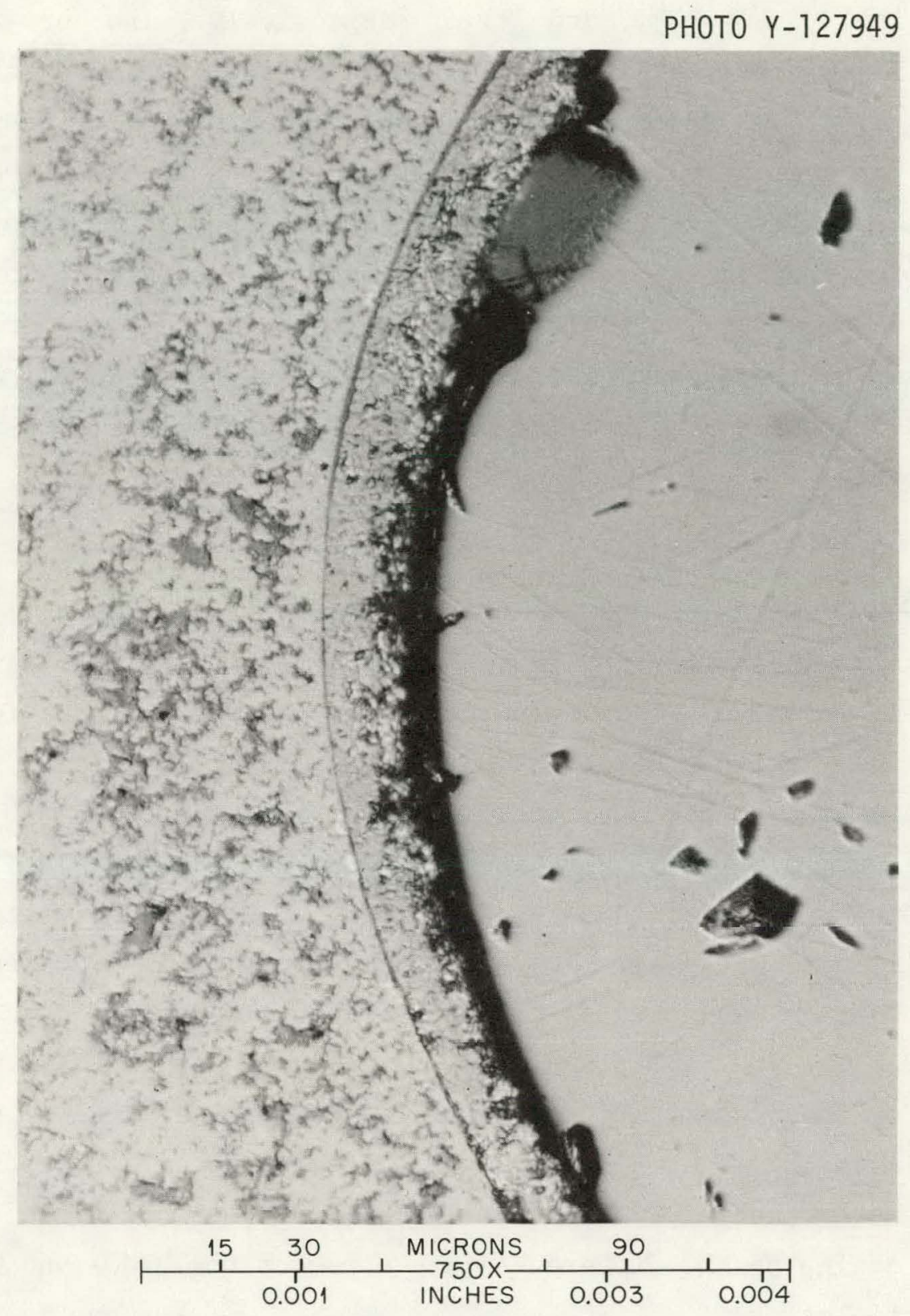

Fig. 8. BISO-coated $\mathrm{ThO}_{2}$ heated in the laboratory for $551 \mathrm{~h}$ at $\sim 1800^{\circ} \mathrm{C}$ and $280^{\circ} \mathrm{C} / \mathrm{cm}$. The crescent-shaped layer is carbon deposited on the cold side of the $\mathrm{ThO}_{2}$ kernel during kernel migration; the $\mathrm{ThO}_{2}$ kernel is shown at the right. 
and $20 \mu \mathrm{m}$ in 159, 309, 435, and $731 \mathrm{~h}$, respectively. Another group of seven particles heated at 1810 to $1935^{\circ} \mathrm{C}$ in a second specimen migrated an average of 4.4, 6.9, and $10.4 \mu \mathrm{m}$ in 143, 365, and $551 \mathrm{~h}$, respectively. A plot of the average $\mathrm{y}$ values for each specimen vs time appeared both to be linear and to pass through the origin. On the other hand, GAC workers noted that in laboratory studies made at $\sim 1500^{\circ} \mathrm{C}$ the onset of migration of previously irradiated $\mathrm{ThO}_{2}$ kernels was delayed for a period of time that decreased with increasing burnup and temperature. 32 The ORNL and GAC results are probably consistent, but further work is needed in this area.

(4) $\mathrm{Th}_{1-\mathrm{z}} \mathrm{U}_{\mathrm{z}} \mathrm{O}_{2}+$ Fission-Product Oxides

Extensive in-reactor KMC data were obtained for kernels having initial compositions in the $\mathrm{UO}_{2}-\mathrm{ThO}_{2}$ solid solution. As was the case for irradiated $\mathrm{UO}_{2}$, the fission-product oxide percentage in the kernel is approximately equivalent to the percent FIMA. The KMC data for Th $0.8^{\mathrm{U}_{0}} \mathrm{O}_{2}$ irradiated from 6.8 to 26\% FTMA are given in Fig. 9 and Table II. A TRISO coating was used in HRB-7-9, ${ }^{19}$ while ${ }^{233} \mathrm{U}$ was used (instead of ${ }^{235} \mathrm{U}$ ) in HRB-6-3A 33 and $O F-1-5-3$. No detectable effect of ${ }^{23} 3_{U}$ content, burnup, or TRISO coatings was noted on the KMC values. In-reactor data for ${ }^{T h} 0.5^{\mathrm{U}_{0}} 0.5^{\mathrm{O}} 2$, Th $0.67^{\mathrm{U}} 0.33^{\mathrm{O}} 2$, and Th $0.98^{\mathrm{U}} 0.17^{\mathrm{O}} 2$ are given in Fig. 10 . The KMC data for these compositions, which lie within the range of KMC values for irradiated Th $0.8_{0.2} \mathrm{U}_{2}$, indicate no discernible effect of the Th/U value on the KMC behavior. The HRB-7-10 and HRB-8-10 particles had TRISO coatings; again, no KMC differences are apparent for BISO- and TRISOcoated particles.

Laboratory experiments I'rom 1500 to $1900^{\circ} \mathrm{C}$ on as-coated $\mathrm{Th}_{0 .} 8^{\mathrm{U}_{0}} ._{2} \mathrm{O}_{2}$ particles were not successful in producing kernel migration.

(5) $\underline{\mathrm{UC}_{2}}$

The KMC data from laboratory studies performed on as-coated particles containing fully-dense $\mathrm{UC}_{2}$ kernels are given in Fig. 11 and Table II. The KMC behavior is considered to be identical to that determined by Stansfield 


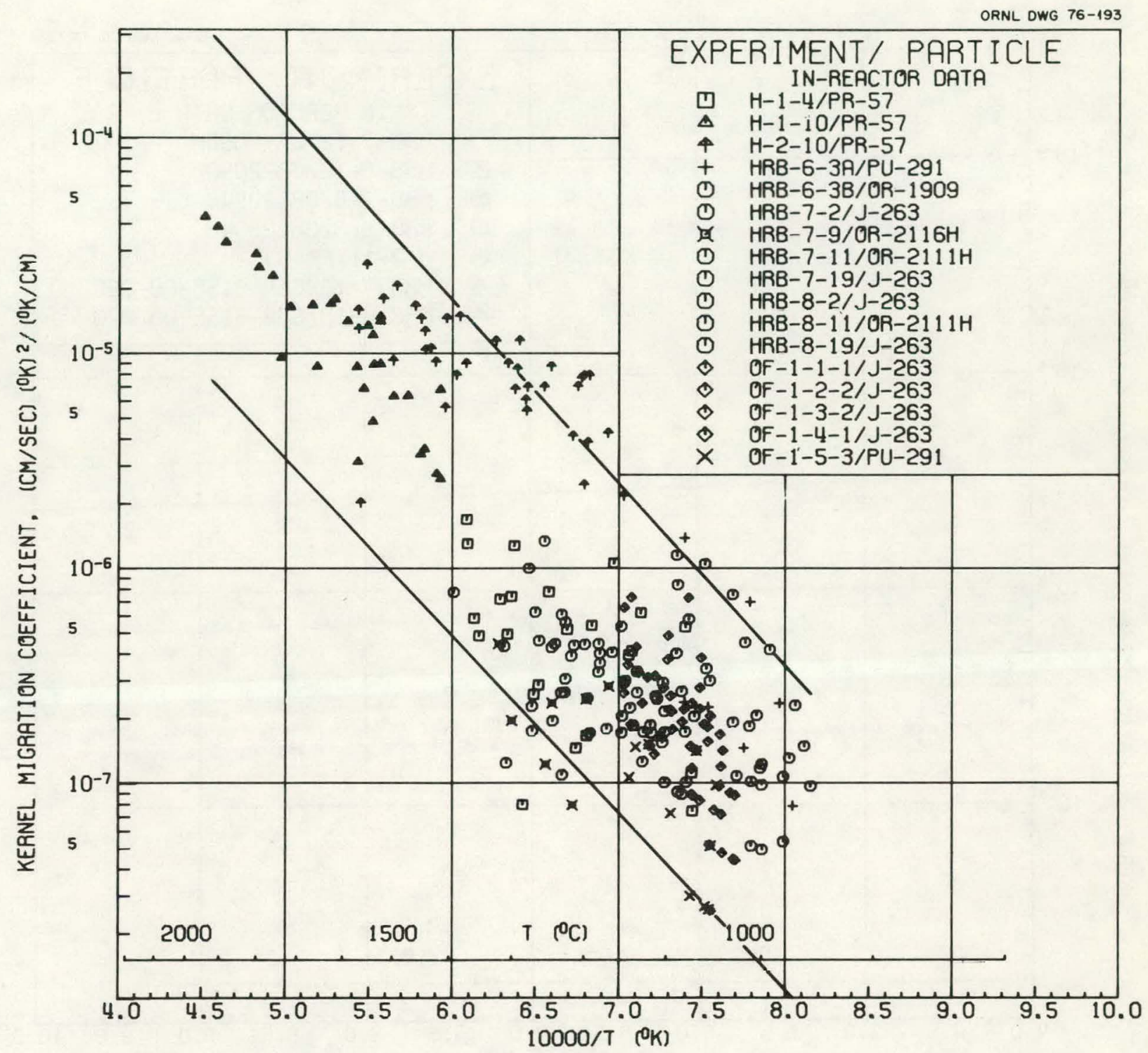

Fig. 9. In-reactor KMC values and their 90\% confidence limits for Th $0.8^{\mathrm{U}} 0.2^{\mathrm{O}} 2$ irradiated from 6.8 to $26 \%$ FTMA. 


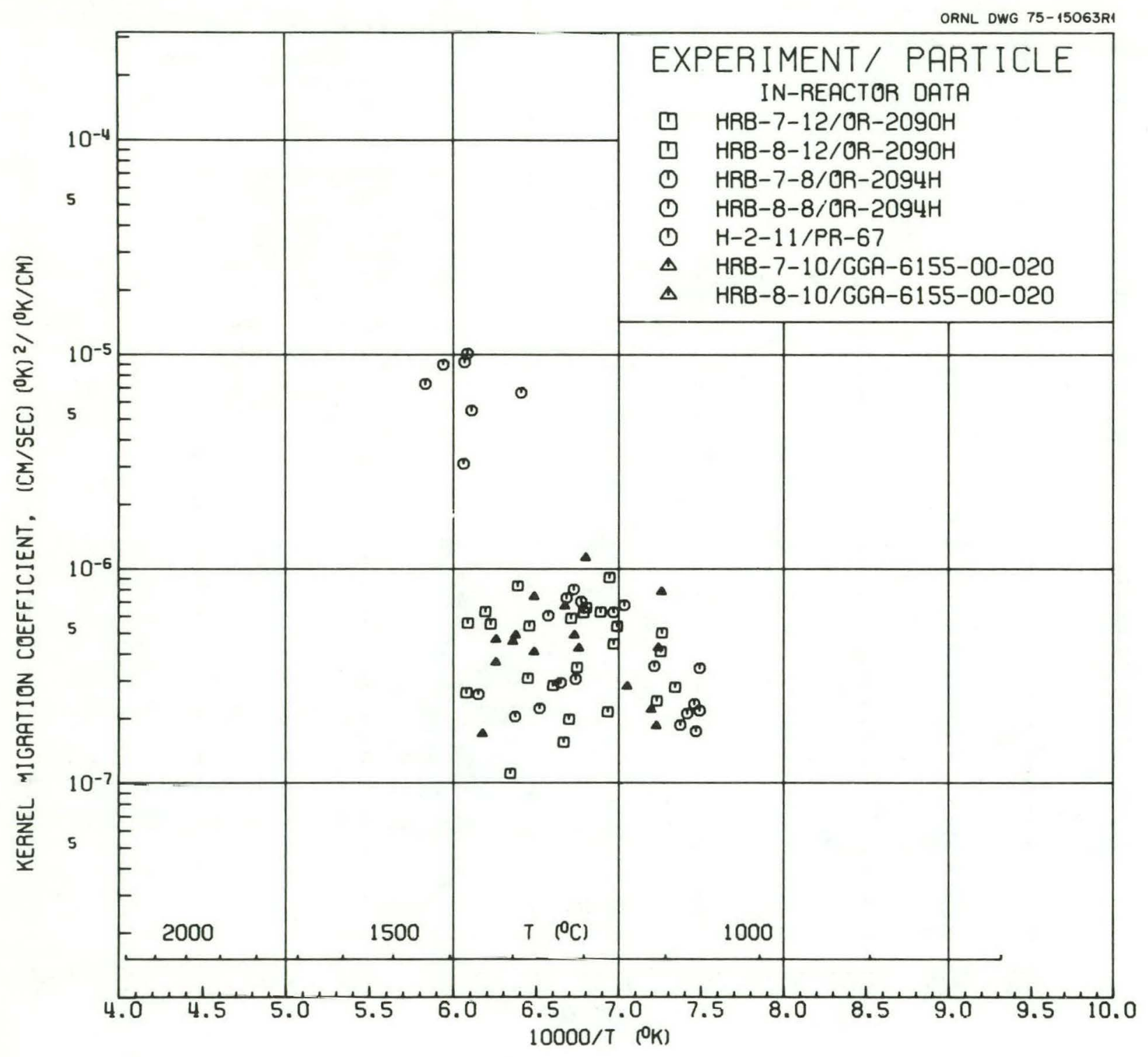

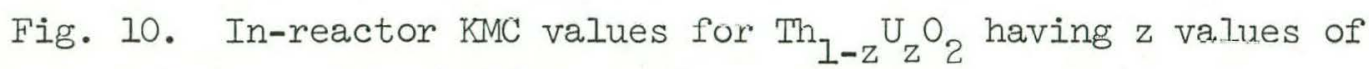
either 0.50 (squares), 0.33 (circles), or 0.11 (triangles). 


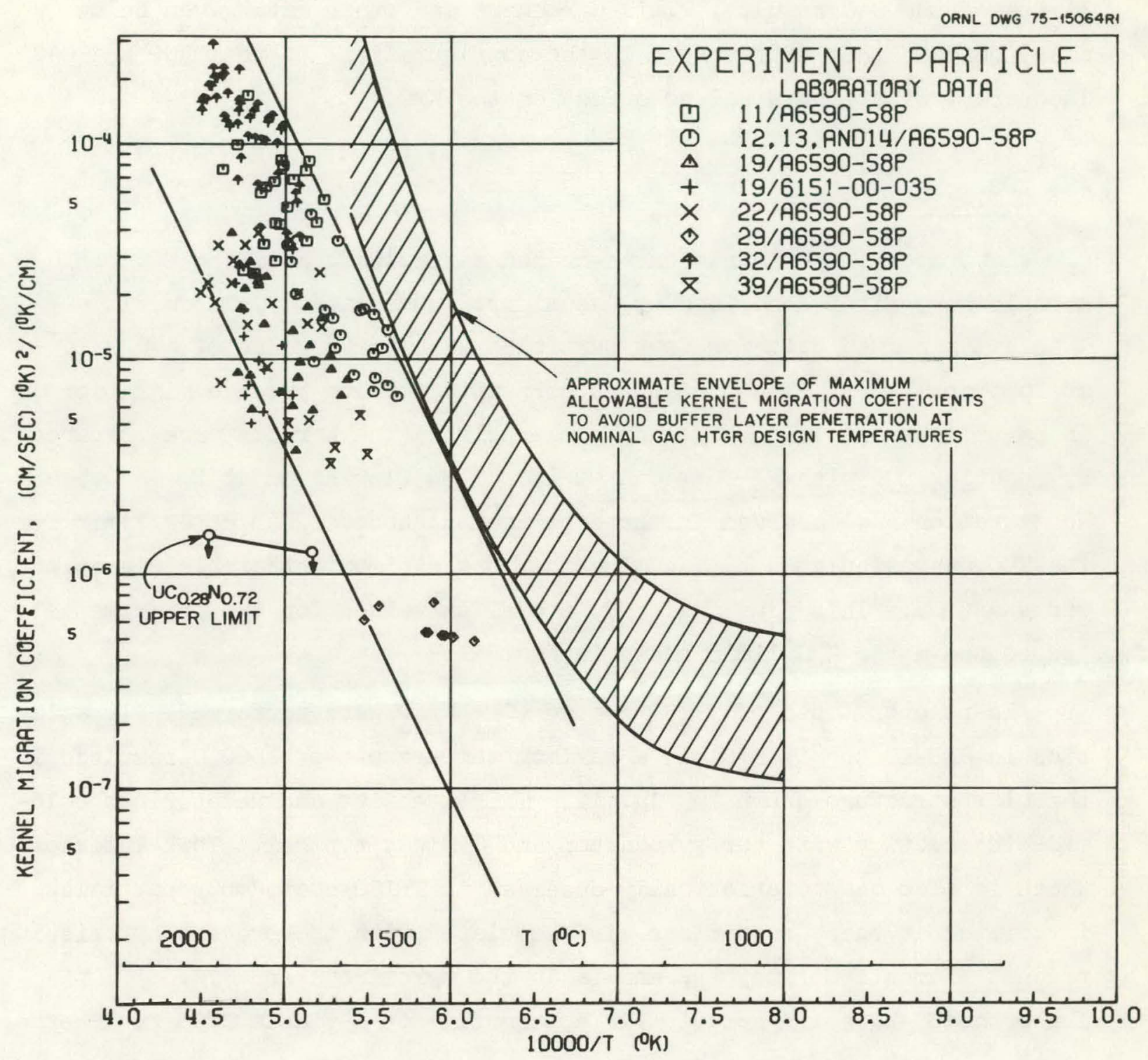

Fig. 11. Laboratory KMC values for as-coated UC ${ }_{2}$; the GAC $90 \%$ confidence limits ${ }^{7}$ for as-coated $\mathrm{UC}_{2}$ are used to illustrate the agreement of the GAC and ORNL data. Also shown is the upper-limit KMC for $\mathrm{UC}_{0.28^{\mathrm{N}} 0.72}$; these kernels did not mierate. The shaded area is the range of the maximum KMC values that are permissible for the present GAC HTGR fuel design. 37 
et al. ${ }^{7}$ since the present data lie essentially within the $90 \%$ confidence limits of the GAC results. This agreement and other data given below also indicate that differences in the configuration ${ }^{7}$ of the ORNL and GAC laboratory experiments had no effect on the KMC.

(6) $\underline{\mathrm{UC}_{1-z^{\mathrm{N}}} \mathrm{N}_{\mathrm{z}}}$

Laboratory experiments on as-coated particles containing $\mathrm{UC}_{0.43^{\mathrm{N}}} 0.57$ kernels were first described by Naoumidis; ${ }^{8}$ subsequently, Naoumidis and Thiele ${ }^{34}$ reported data for four particles with a KMC value of $\sim 6 \times 10^{-6}$ at 1675 to $1730^{\circ} \mathrm{C}$. The present authors attempted to produce migration in particles containing $\mathrm{UC}_{0.28^{\mathrm{N}}} 0.72$ kernels. (The kernels were prepared by reacting $\mathrm{UC}_{2}$ with $\mathrm{N}_{2}$ for $48 \mathrm{~h}$ at $1700^{\circ} \mathrm{C}$ in flowing $\mathrm{N}_{2}$ at $\mathrm{P}_{\mathrm{H}_{2}}=0.5 \mathrm{~atm}$.) No migration was observed in the experiments; however, an upper limit for the KMC was calculated by assuming that the minimum detectable migration was $y=2 \mu \mathrm{m}$. This plus the $t, T$, and $d T / d x$ values for the experiments led to the upper KMC limit shown in Fig. 1 .

In-reactor tests of TRISO-coated UC $0.4^{\mathrm{N}} 0.6$ were performed. Irradiation in HRB-10 to $80 \%$ FIMA at a maximum temperature of $1500^{\circ} \mathrm{C}$ resulted in the microstructure shown in Fig. 12. The extensive and deleterious coldside interaction with the pyrocarbon and Sil was typical. This intarastinn, which is also characteristically observed in TRISO-coated $\mathrm{UC}_{2}$ particles irradiated at these conditions, is associated with the presence of fissionproduct elements $\mathrm{Nd}, \mathrm{Ce}, \mathrm{Pr}$, and La in the pyrocarbon and SiC. ${ }^{19,32,35}$ Thus, the UC-UN solid solution is apparently not a viable HTGR fuel kernel.

\section{(7) $\mathrm{ThC}_{2}$}

The ORNL in-reactor KMC data for $\mathrm{ThC}_{2}$ obtained in irradiation $\mathrm{H}-1-9^{20}$ are shown in Fig. 13. It is apparent that the in-reactor results do not entirely agree with the laboratory results on as-coated particles. This discrepancy is analyzed in the Discussion section.

The laboratory KMC data for as-coated particles furnished by GAC from four different coating runs are given in Fig. 13 and Table II. These KMC 


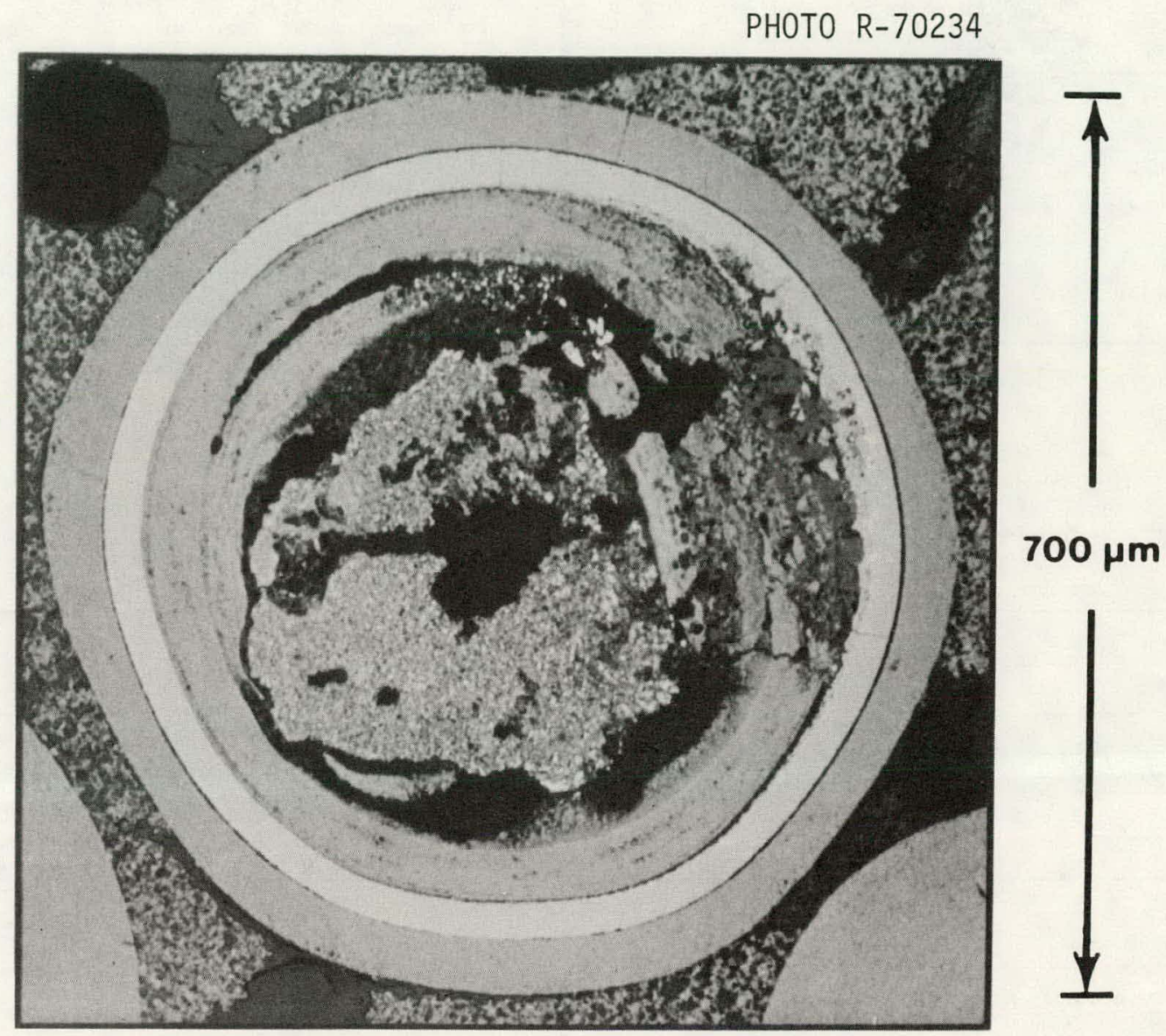

Fig. 12. Bright-field photomicrograph of TRISO-coated $\mathrm{UC}_{0.4} \mathrm{~N}_{0.6}$ irradiated to $\sim 80 \%$ FIMA at $n .1100^{\circ} \mathrm{C}$ and $\sim 650^{\circ} \mathrm{C} / \mathrm{cm}$ in the $\mathrm{HRB}-10$ capsule. Cold-side interactions with the coatings are typically associated with the $\mathrm{La}, \mathrm{Pr}, \mathrm{Ce}$, and Nd fission products. 


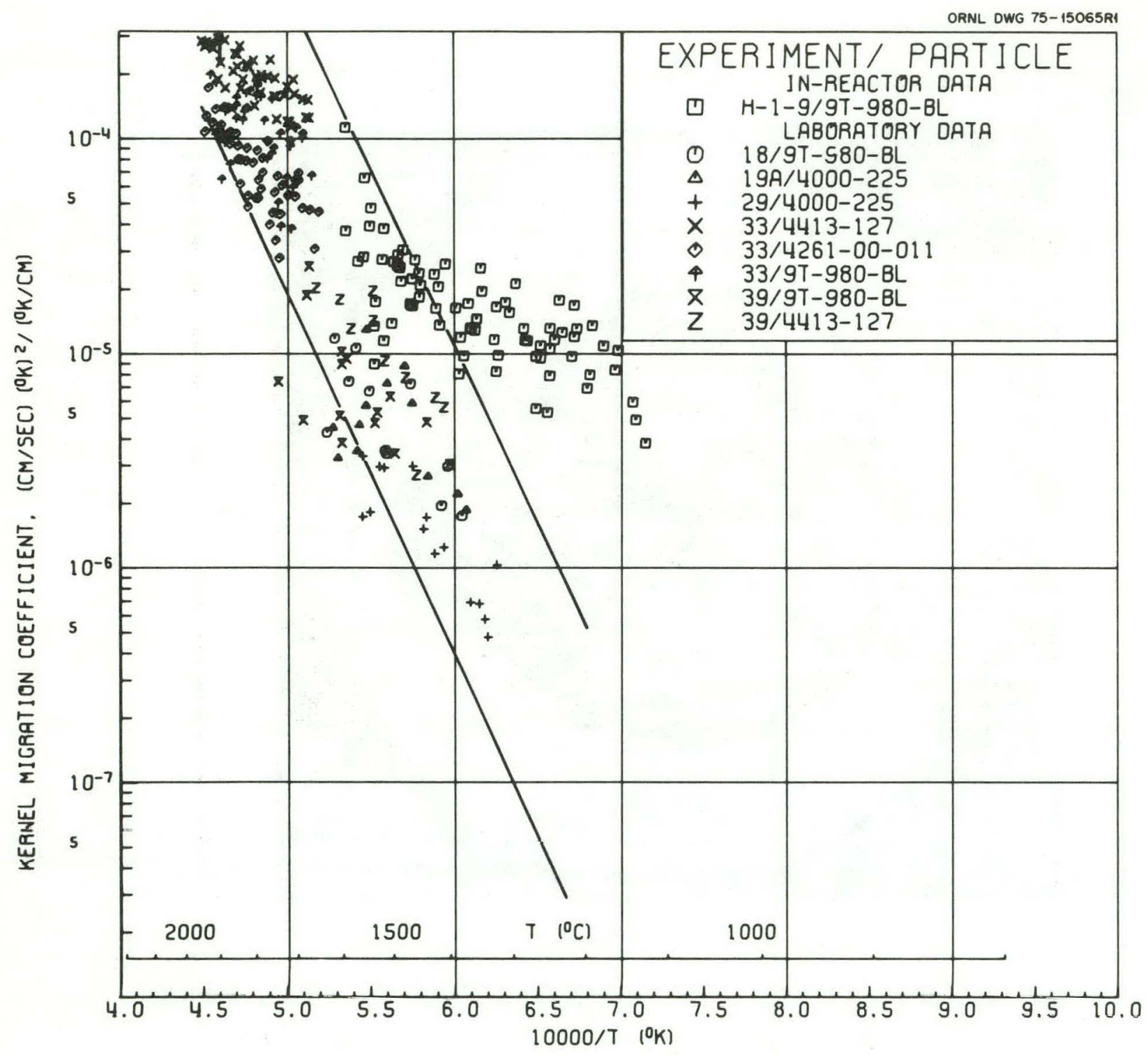

Fig. 13. Laboratory $K M C$ values for as-coated $\mathrm{ThC}_{2}$ and in-reactor $T_{2} \mathrm{C}_{2}$ KMC values. The H-l-9 values are probably atypical since the kernels completely penetrated the particle coatings during irradiation. The GAC $90 \%$ confidence limits ${ }^{7}$ for as-coated $\mathrm{ThC}_{2}$ are shown to illustrate the agreement of the laboratory data obtained at ORNL and at GAC. 
values are consistent with the confidence limits reported by Stansfield et al. 7

(8) $\operatorname{Th}_{0.84^{\mathrm{U}} 0.16^{\mathrm{C}} 2}$

In-reactor KMC data were obtained for $\mathrm{Th}_{0.84} \mathrm{U}_{0.16} \mathrm{C}_{2}$ from fuel element EII-07, which had been irradiated to $~ 9 \%$ FMMA in the Peach Bottom reactor. Two annular fuel compacts were examined metallographically and the kernel migration measured. The time-dependent thermal analysis was provided by GAC, ${ }^{36}$ and Eq. (4) was used to calculate the $\overline{\mathrm{T}}_{\max }$ shown in Table I. The resulting KMC values, shown in Fig. 14, appear to be higher than the most recent GAC confidence limits for as-coated $\mathrm{Th}_{1-z} \mathrm{U}_{z} \mathrm{C}_{2}$ particles. 37 This discrepancy is analyzed in the Discussion section.

Laboratory KMC data were obtained on as-coated $\mathrm{Th}_{0.84} \mathrm{U}_{0.16} \mathrm{C}_{2}$. An archive fuel compact identical to those irradiated in the Peach Bottom reactor was available. A core drill was used to remove a $1.27-\mathrm{cm}$-diam. cylinder of matrix and fuel particles from the compact, and a low-speed diamond saw was used to slice a $0.09-\mathrm{cm}-$ thick disc from the cylinder. This disc was mounted as shown in Fig. 1; heating resulted in the KMC data shown in Fig. 14. Again, these data are consistent with the most recent GAC confidence limits for $\mathrm{Th}_{I-z} \mathrm{U}_{\mathrm{z}} \mathrm{C}_{2} \cdot 37$

\section{Discussion}

\section{(1) Carbide Results}

The in-reactor dicarbide data require further general comment. The $\mathrm{ThC}_{2} \mathrm{KMC}$ data from fuel rod H-1-9 (Fig. 13) clearly disagree with the laboratory data for as-coated $T_{2} C_{2}$. One might first suspect the accuracy of the thermal analysis. However, the accuracy appears reasonable since the thermal analyses for all the $\mathrm{H}-1$ and $\mathrm{H}-2$ fuel rods were performed simultaneously and the KMC values obtained from $\mathrm{H}-\mathrm{I}$ and $\mathrm{H}-2$ fuel rods con-

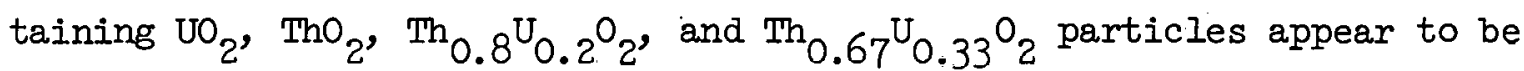
consistent with KMC data from other irradiations. The primary difference between the $\mathrm{H}-1-9$ specimens and others was that the $\mathrm{ThC}_{2}$ kernels from 


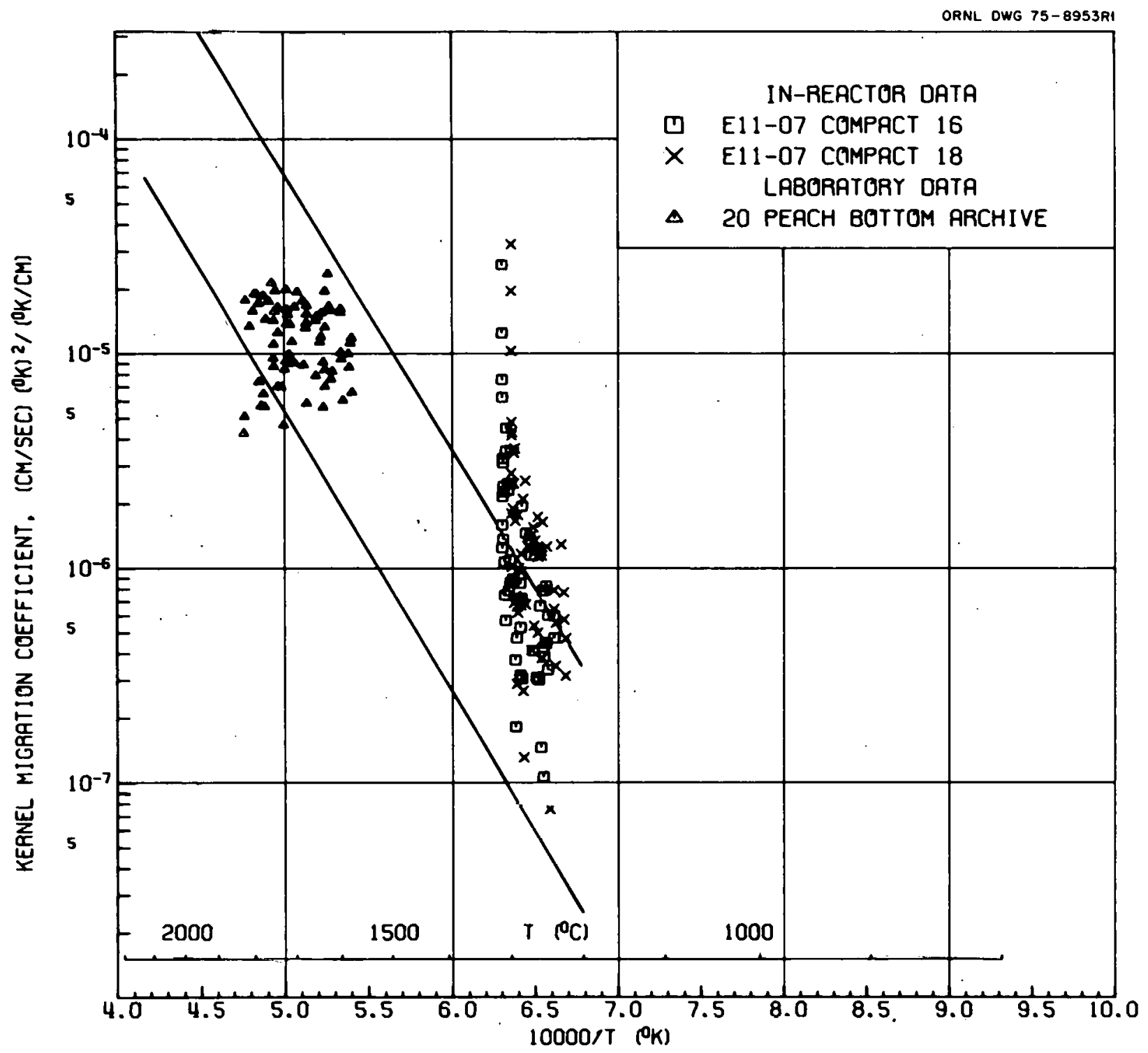

Fig. 14. Th $0.84^{\mathrm{U}} 0.16^{\mathrm{C}} 2 \mathrm{KMC}$ values for particles in a fuel compact irradiated to $~ 9 \%$ FIMA and for particles from the same coating batches in a comparable archive compact. The most recent GAC $90 \%$ confidence limits ${ }^{38}$ are used here. 
H-1-9 had generally completely penetrated the particle coatings and often had progressed into the fuel rod matrix. For this reason alone, the H-I-9 data are to be considered atypical.

The KMC data for Th $0.84 \mathrm{U}_{0.16^{\mathrm{C}} 2}$ particles from the Ell-07 fuel element (Fig. 14) straddle the upper confidence limit of the laboratory KMC data. Given the probable temperature uncertainty of $\pm 100^{\circ} \mathrm{C}$ and a probable uncertainty of $\sim 30 \%$ in $\mathrm{dT} / \mathrm{dx}$, one could not definitely conclude that the in-reactor KMC data were inconsistent with the laboratory data. Thus, further irradiation results would be necessary before one could substantiate the conclusion of Stansfield et al. ${ }^{7}$ that the in-reactor and laboratory KMC values for the dicarbides are indistinguishable.

\section{(2) Oxide Results}

Control of the oxide kernel migration rate by a solid-state diffusion mechanism is firmly indicated. Analyses of the in-reactor $\mathrm{Th}_{1-\mathrm{z}} \mathrm{U}_{\mathrm{z}} \mathrm{O}_{2}$ and $\mathrm{UO}_{2}$ migration data (Fig. 4 and Ref. 15) clearly favor the solid-state diffusion mechanism. Also, workers both at $\mathrm{GAC}^{31}$ and at $\mathrm{ORNL}^{20}$ have observed intergranular graphitic deposits within the cooler portion of Tho ${ }_{2}$ particles migrating in-reactor; a similar deposit has been noted in $\mathrm{UO}_{2}{ }^{\circ}$ This phenomenon is not inconsistent with a solid-state transport process operating across the kernel. The few $\mathrm{ThO}_{2}$ kernels that displayed observable migration in the $\mathrm{HRB}-3$ irradiation were located at approximately two-thirds of the fuel rod radius, ${ }^{22}$ which is again in accordance with migration control by a volidatatc diffusion mechanism.

Several observations can be used to argue against control of the migration rate by gas-phase, $\mathrm{CO}-\mathrm{CO}_{2}$ diffusion. The calculated in-reactor migration behavior for $\mathrm{ThO}_{2}$ resulting from control by the $\mathrm{CO}_{-} \mathrm{CO}_{2}$ gas phase diffusion mechanism (see Fig. 3) differs significantly from the actual KMC behavior (see Fig. 7). Sayers et al. ${ }^{38}$ have used the same reasoning to conclude that $\mathrm{UO}_{2}$ kernel migration behavior is inconsistent with control by the $\mathrm{CO}-\mathrm{CO}_{2}$ mechanism. The $\mathrm{CO}$ plus $\mathrm{CO}_{2}$ overpressures and, thus, the predicted gas-phase transport rates differ by an order of magnitude or more both in as-coated $\mathrm{ThO}_{2}$ vs irradiated $\mathrm{ThO}_{2}$ and in the as-coated $\mathrm{UO}_{2}-\mathrm{U}_{2} \mathrm{~N}_{3}$ 
solid solution vs irradiated $\mathrm{UO}_{2}$. Nevertheless, one obtains apparently interconsistent $\mathrm{KMC}$ values within the $\mathrm{ThO}_{2}$ system as well as within the $\mathrm{UO}_{2}$-based system.

The presence of in-particle gas atmospheres may nevertheless play a significant role in establishing chemical potential gradients and lattice defect structures for solid-state diffusion in oxide particles. Workers at GAC noted that oxide kernel migration ceased when the coating failed and postulated that this was a consequence of the loss of the kernel atmosphere. 31 The oxygen chemical potential gradient may be involved in the driving force for the solid-state diffusion of the undetermined rate-controlling species and can be calculated by methods suggested by Aitken's work. 39 In this case the driving force, $\mathrm{X}_{\mathrm{O}_{2}}$, is $-\mathrm{T} \operatorname{grad}\left(\Delta \mathrm{F}_{\mathrm{T}}^{\circ} / \mathrm{T}+\right.$ $2 \mathrm{R}$ In $\left.\mathrm{P}_{\mathrm{CO}}\right)$, where the Gibbs free energy change for the equilibrium is $\Delta F_{T}^{\circ} \approx-56,500$ - 4OT. Thus, $X_{O_{2}}$ is relatively insensitive to $P_{C O}$, which may partially explain why the KMC for oxides is insensitive to burnup even though $\mathrm{P}_{\mathrm{CO}}$ apparently increases significantly with burnup. On the other hand, a significant decrease of $\mathrm{P}_{\mathrm{CO}}$ by the addition of secondphase carbides to the $\mathrm{UO}_{2}$ and $\mathrm{Th}_{1-\mathrm{z}} \mathrm{U}_{2} \mathrm{O}_{2}$ kernels has also led to the apparent elimination of kernel migration. Sayers et al. ${ }^{38}$ reported that SiC was an effective additive, while Naoumidis and Thiele ${ }^{34}$ and Nickel and Balthesen ${ }^{10}$ reported that $\mathrm{UC}_{2}$ and $\mathrm{Th}_{1-\mathrm{z}} \mathrm{U}_{\mathrm{Z}} \mathrm{C}_{2}$ were effective. WagnerLöffler et al. 41 have also proposed TiC and $\operatorname{ZrC}$ additions. These additions establish a specific oxide-carbide equilibrium, such as $\mathrm{UO}_{2}+4 \mathrm{C} \rightarrow$ $\mathrm{UC}_{2}+2 \mathrm{CO}$ with $\mathrm{X}_{\mathrm{O} .2}=\mathrm{T} \operatorname{grad}(-238,000 / \mathrm{T}+43.9)$. These equilibria have $\mathrm{P}_{\mathrm{CO}}$ values that are orders of magnitude smaller than those in $100 \%$ oxide particles at normal HTGR temperatures. However, it can be shown that $\mathrm{X}_{\mathrm{O}}$ values calculated from the two quantitative expressions given immediately above have the same sign and magnitude. Thus, these driving forces are apparently not significantly affected by large changes in $\mathrm{P}_{\mathrm{CO}}$, or equivalently, $\mu_{\mathrm{O}_{2}}$. Thus, one must look elsewhere to explain the effect of $\mathrm{H}_{2}$ on the solid-state diffusion mechanism. It appears that a likely explanation lies in the $\mathrm{H}_{2}$ dependence of the interaction of the lanthanide fission-product oxides in extensive solid solution with the uranium oxide to form $\mathrm{UO}_{2+\mathrm{x}^{*}}$ (Collectively, $\mathrm{Y}$ and the lanthanide fission products from 
$233_{U}$ and ${ }^{235} \mathrm{U}$ in a thermal neutron flux have a yield of 55\%.) In $100 \%$ oxide particles, the $\mathrm{CO}$ generated during fission results in $\mu_{\mathrm{O}_{2}}$ values in the range of $-120 \leq \mu_{\mathrm{O}_{2}} \leq-90 \mathrm{kcal} / \mathrm{mol}$ for $1000 \leq \mathrm{T} \leq 1500^{\circ} \mathrm{C} .6{ }^{2}, 17$ Thermodynamic data at these $\mu_{\mathrm{O}_{2}}$ values for the U-La-O, ${ }^{42,43} \mathrm{U}-\mathrm{Y}-\mathrm{O},{ }^{43} \mathrm{U}-\mathrm{Ce}-\mathrm{O},{ }^{44}$ and $\mathrm{U}-\mathrm{Nd}-\mathrm{O}^{45}$ systems indicate $\mathrm{O} / \mathrm{U}$ ratios in the range 2.001 to 2.2 would occur. ${ }^{17}$ It is known that increasing hyperstoichiometry significantly increases the self-diffusion coefficient of oxygen; 46 presumably this would similarly affect the diffusion of other "anions" such as solidsolution carbon. The migration observed in the as-coated $\mathrm{UO}_{2}-\mathrm{U}_{2} \mathrm{~N}_{3}$ solid solution (see Fig. 5) may also be a direct result of a lattice defect structure that is comparable to that for the $\mathrm{UO}_{2}$ plus lanthanide oxide solid solution. The lack of the lanthanide oxides and hyperstoichiometry in as-coated $\mathrm{UO}_{2}$ may also explain why as-coated $\mathrm{UO}_{2}$ does not migrate. Finally, addition of $\mathrm{UC}_{2}$ to the $\mathrm{UO}_{2}$ kernel would lower the $\mu_{\mathrm{O}_{2}}$ sufficiently to preclude any hyperstoichiometry in the $\mathrm{UO}_{2}$-lanthanide oxide system, thus significantly reducing both the solid-state diffusion rate in the anion sub-lattice and the in-reactor kernel migration rate.

It is clear that a more precise understanding of the thermodynamic and kinetic factors affecting oxide kernel migration is desirable. To a great extent this future understanding will be dependent on information on as-yet uninvestigated thermodynamic and kinetic phenomena at HTGR fuel temperatures and $\mu_{\mathrm{O}_{2}}$ values in actinide oxides containing typical amounts of fission products. Future quantitative kernel migration theories based on this information could then be applied to the kemel migration data given in Refs. 22 and 23.

\section{(3) Application of Data to HTGR Fuel Design}

Gulden et al. ${ }^{35}$ have discussed the GAC HTGR fuel design criteria that affect the selection of kernel compositions. These criteria were expressed in terms of maximum acceptable KMC values by setting $\mathrm{y}$ at a constant value which represented an acceptable total amount of kernel migration, and by properly incorporating $t$ and the time-dependent $T$ and $\mathrm{dT} / \mathrm{dx}$ characteristics of the fuel design. This range of maximum KMC 
values is shown as the shaded area in Fig. 1l. Actual KMC values lying below the design-based KMC were acceptable, while those within or above were not. By this means, fully-dense $\mathrm{UO}_{2}$ and $\mathrm{Th}_{1-\mathrm{z}} \mathrm{U}_{2} \mathrm{O}_{2}$ kernels were found to have unacceptably high KMC values and hence were not considered further for the GAC HTGR design. The KMC values for thoria and all the dicarbide fuel kernels were acceptable. Other HTGR fuel designs may have maximum acceptable KMC values different from those in Fig. Il; for example, if $\mathrm{dT} / \mathrm{dx}$ in another design were 0.1 of the GAC $\mathrm{dT} / \mathrm{dx}$ values, then the shaded area would lie at KMC values that were higher by a factor of 10 . Consequently, the KMC values for $\mathrm{Th}_{1-z} \mathrm{U}_{z} \mathrm{O}_{2}$ and $\mathrm{UO}_{2}$ would also be acceptable.

\section{Conclusions}

Several conclusions may be drawn from the data and analyses presented here. These are as follows:

(1) The previously published technique ${ }^{6,15}$ for determining the in-reactor, rate-controlling mechanism for kernel migration has been validated with $\mathrm{Th}_{0} 0.84^{\mathrm{U}} 0.16^{\mathrm{C}} 2$ data. This reinforces the conclusion ${ }^{6,15}$ that the kernel migration rate for $\mathrm{UO}_{2}$ plus fission-product oxides is controlled by a solid-state diffusion mechanism operating across the kernel.

(2) In-reactor migration of fissioned $\mathrm{Th}_{0} 8^{\mathrm{U}_{0}} \mathrm{O}^{\mathrm{O}} \mathrm{O}_{2}$ appears to be controlled by a solid-state diffusion mechanism.

(3) The $\mathrm{ThO}_{2}$ kernel migration rate does not appear to be controlled by the rate of carbon transport resulting from in-particle $\mathrm{CO}-\mathrm{CO}_{2}$ diff'fusion. Circumstantial evidence suggests that solid-state diffusion is the controlling mechanism.

(4) The oxide KMC derived from solid-state diffusion theory appears to correlate the migration data for $\mathrm{UO}_{2}$ plus fission-product oxides, $\mathrm{ThO}_{2}$ and $\mathrm{ThO}_{2}$ plus fissionproduct oxides, and $\mathrm{Th}_{1-z} \mathrm{U}_{\mathrm{z}} \mathrm{O}_{2}$ plus fission-product 
oxides. No dependence of burnup, BISO-Vs-TRISO coatings, or ${ }^{233} \mathrm{U}$ vs ${ }^{235} \mathrm{U}$ content on the KMC values was discernible. The KMC values for $\mathrm{Th}_{1-z} \mathrm{U}_{\mathrm{z}} \mathrm{O}_{2}$ appeared to be independent of composition in the range $0.11 \leq \mathrm{z} \leq 0.50$.

(5) The kernel migration rate for as-coated $\mathrm{ThO}_{2}$ as determined in the laboratory appears to be linear with time at 1810 to $1945^{\circ} \mathrm{C}$.

(6) The laboratory KMC data obtained by ORIL and by GAC for dicarbide kernels appear to be in excellent agreement. In view of the uncertainties for in-reactor temperature calculations, the in-reactor and laboratory KMC values do not appear to be inconsistent.

(7) The irradiation performance of nitrogen-containing oxide or carbide kernels was no better than that of analogous nitrogen-free kernel compounds. Consequently, nitrogen additions to HTGR fuels do not appear to be warranted.

Acknowledgments: The authors wish to thank $\mathrm{H}$. J. de Nordwall for his consultation and encouragement during the initial stages of this study. The authors also wish to thank R. L. Beatty, G. W. Weber, E. L. Long, Jr., N. M. Atchley, W. D. Mason, and L. G. Shrader for their assistance with particle preparation and examination. C. L. Smith and J. R. Sims, Jr., of $\mathrm{GAC}$ provided $\mathrm{UC}_{2}$ and $\mathrm{ThC}_{2}$ particles as well as current information from their kernel migration experiments. Betty Drake and Martha Stewart provided valuable assistance with manuscript preparation. 
References* $^{*}$

1. M. S. T. Price, J. R. G. Gough, and G. W. Horsley, "Fuel Element Fabrication for the Dragon Reactor Experiment," J. Brit. Muc.t.. Energy Soc. ㄴ, 361-82 (1966).

2. H. W. Muller, C. B. van der Decken, U. Hennings, and W. Stummer, "The AVR Pebble Bed Reactor," ibid. 5, 319-31 (1966).

3. R. C. Dahlberg, R. F. Turner, and W. V. Goedel, "Fort Saint Vrain Core Design Characteristics," Ihucl. Eng. Intern. 14, 1073-77 (1969).

4. L. R. Shepherd, "Development of Coated Particle Fuels for High Temperature Reactors," J. Brit. Nucl. Energy Soc. 9, 173-88 (1970).

5. R. A. U. Huddle, "Fuel Elements for High Temperature Reactors: Basic Materials Philosophy of the Dragon Programme," pp. 631-45 in Proceedings of the Symposium on Advanced and High-Temperature GasCooled Reactors, Jülich, IAEA, Vienna, 1968.

6. T. B. Lindemer and H. J. de Nordwall, "An Analysis of Chemical Failure of Coated $\mathrm{UO}_{2}$ and Other Oxide Fuels in the High-Temperature Gas-Cooled Reactor," Tech. Rept. ORNL-4926, 1974.

7. O. M. Stansfield, C. B. Scott, and J. Chin, "Kernel Migration in Coated Carbide Fuel Particles, " Nucl. Technol. 25, 517-30 (1975).

8. A. Naoumidis, "Supressing the Amoeba Effect in Coated Particles with Carbide Kernels for the High Temperature Reactor, "J. Nucl. Mater. . $\underline{\underline{48}}, 118-24(1973)$.

9. - O. M. Stansfield, T. D. Gulden, and D. P. Harmon, "Fuel Kernels for the Thorium Cycle HTGR, " Paper No. 35, Proceedings of the International Conference on Nuclear Fuel Performance, London, Oct. 1973, British Nuclear Energy Society, London, in press; Tech. Rept. Gulf-GA-A12632, June 1973 .

* Copies of most of the ORIJ and GAC reports listed here are available from National Technical Information Service, U.S. Dept. of Commerce, 5285 Port Royal Road, Springfield, Virginia 22151. 
10. H. S. Carslaw and J. C. Jaeger, Conduction of Heat in Solids; p. 191. Oxford University Press, London, 1959.

11. T. D. Gulden, "Carbon Thermal Diffusion in the $\mathrm{UC}_{2}-\mathrm{C}$ System, " J. Am. Ceram. Soc. 55, 14-18 (1972).

12. S. R. DeGroot, Thermodynamics of Irreversible Processes. NorthHolland Publishing Co., Amsterdam, 1958.

13. D. D. McCracken, A Guide to Fortran IV Programming; p. 31. John Wiley and Sons, Inc., New York, 1965.

14. F. J. Homan, "Thermal Analysis of HTGR Fuel Rods Irradiated in the HFIR Removable Beryllium Facility," ORNL/TM report in preparation.

15. T. B. Lindemer, H. J. de Nordwall, and R. A. Olstad, "Analysis and Measurement of Mass Transport in Coated $\mathrm{UO}_{2}$ and other HTGR Oxide Particles, " pp. 163-71 in Proceedings of the Conference on Thermodynamics of Nuclear Materials 1974, IAEA, Vienna, 1975.

16. R. H. Flowers and G. W. Horsley, "The Influence of Oxide Kernels on the Manufacture and Performance of Coated Particle Fuel, "Atomic Energy Research Establishment (England) Report AERE-R5949, 1968.

17. M. J. Kania, T. B. Lindemer, M. T. Morgan, and J M Robbins, "Irradiation Performance of HTGR Fertile Fuel in HFIR Target Capsules HT-I2 Through HT-15: Part I - Experiment Description and Fission Product Behavior," Tech. Rept. ORNL/TM-5305, 1976.

18. J. C. Janvier, M. Bruet, and R. Blanchard, "Fission Gas Pressure Evolution in Irradiated Coated Particles, " Preprint No. 34, Proceedings of the Conference on the HTGR, London, 1973, British Nuclear Energy Society.

19. K. H. Valentine et al., "Irradiation Performance of HTGR Fuel Rods in HFTR Experiments IRRB-7 and -8, " ORNL report in preparation.

20. R. A. Qlsta.t, A. R. Olzen, R. B. Fitts, E. I. Long, Jr., and T. B. Lindemer, "An Irradiation Test of Candidate HTGR Recycle Fuels in the H-1 and H-2 Capsules, "Tech. Rept. ORNL/TM-4374, 1974 . 
21. R. A. Olstad and E. L. Long, Jr., "An Irradiation Test of Candidate HTGR Recycle Fuels in the H-I and H-2 Capsules, "Tech. Rept. ORNL/TM-4397 (addendum), 1975.

22. T. B. Lindemer and R. A. Olstad, "HTGR Fuel Kernel Migration Data. for the Th-U-C-O System as of April 1, 1974, "Tech. Rept. ORNL/TM4493, 1974.

23. T. B. Lindemer and R. L. Pearson, "Kernel Migration in HTGR Fuels from the Th-U-C-O-N System," Tech. Rept. ORNL/TM-5207, 1976.

24. M. G. Natrella, Experimental Statistics, National Bureau of Standards Handbook 91, pp. 5.10, 5.45. Supt. of Documents, U.S. Govt. Printing Office, Washington, D.C., 1966.

25. "HTGR Base Program Quarterly Progress Report for the Period Ending Nov. 30, 1973," Tech. Rept. Gulf-GA-A12818, 94-96, 1973.

26. J. M. Martin, "The Phase Diagrams of $\mathrm{U}-\mathrm{UN}-\mathrm{UO}_{2}$ and $\mathrm{UO}_{2}-\mathrm{UN}_{-} \mathrm{N}_{2}$," J. Nucl. Mater. 34, 81-85 (1970).

27. R. Benz, A. Balog, and B. H. Baca, "U-UO $2-U_{2}$ Phase Diagram, " $\underline{\text { High }}$ Temp. Sci. 2, 221-51 (1970).

28. J. M. Leitnaker and T. B. Lindemer, Oxynitride Fuel for Gas-Cooled Reactor Fuel Particles, U.S. Pat. 3874041, April 15, 1975.

29. F. J. Homan et a.l., "Irradiation Performance of HTGR Fuel Rods in HFIR Experiment HRB-3 and ETR Experiment PI3N," Tech. Rept. ORNL/TM-4526, 1974.

30. F. J. Homan et al., "Irradiation Performance of HTGR Fuel Rods in HFIR Experiments HRB-4 and -5," Tech. Rept. ORNL/TM-5115, 1976.

31. "HTGR Fuels and Core Development Program, Quart. Prog. Rept. Period Ending May 31, 1975," Tech. Rept. GA-A13444, 31-160, 1975.

32. O. M. Stansfield, "HTGR Fuel Design and Performance," Tech. Rept. GA-Al3072, 1974 .

33. F. J. Homan, E. L. Long, Jr., B. H. Montgomery, R. L. Hamner, and K. H. Valentine, "Irradiation Performance of HTGR Fuel Rods in HFIR Experiment HRB-6," Tech. Rept. ORNL/TM-5011, 1975. 
34. A. Naoumidis and B. A. Thiele, "Studies on the Amoeba Effect: Carbon Transport in Coated Fuel Particles Under Temperature Gradient, " pp. 173-86 in Proceedings of the Conference on Thermodynamics of Nuclear Materials 1974, IAEA, Vienna, 1975.

35. T. D. Gulden, J. L. Scott, and C. Moreau, "Present Thorium-Cycle Fuel Concepts and Performance Limitations, " pp. 176-200 in Proceedings of the Symposium on Gas-Cooled Reactors: HTGR and GCFBR, Gatlinburg, Tenn., May 7-10, 1974; CONF-740501, American Nuclear Society, Hinsdale, IIl., 1974; also Tech. Rept. GA-Al2877.

36. C. F. Wallroth, General Atomic Co., private communication, June 1975.

37. J. R. Sims, Jr., C. L. Smith, and C. B. Scott," Migration of Unirradiated (Th, U)C ${ }_{2}$ Kernels, "Tech. Rept. GA-Al3825 (1976).

38. J. B. Sayers et al., "Coated Particle Fuels for the Low Enriched Fuel Cycle HTR, " Paper No. 32, Proceedings of the International Conference on Nuclear Fuel Performance, London, Oct. 1973, British Nuclear Energy Society, London, in press.

39. E. A. Aitken, "Thermal Diffusion in Closed Oxide Fuel Systems," J. Nucl. Mater. 30, 62-73 (1969).

40. H. Nickel and E. Balthesen, "Status of HTR Fuel Element Development in the FRG and Its Potential for Nuclear Process Heat Reactors," Kerntechnik $\stackrel{5}{=}$ 205-14 (1975):

41. M. Wagner-Loffler et al., "The Significance of Gas-Pressure Build-Up in Coated Particles," Paper No. 36, Proceedings of the International Conference on Nuclear Fuel Performance, London, Oct. 1973, British Nuclear Energy Society, London, in press.

42. E. Stadlbauer, U. Wichmann, U. Lott, and C. Keller, "Thermodynamics and Phase Relationships of the Ternary Lanthanum-Uranium-Oxygen System," J. Solid State Chem. 10, 341-50 (1974).

43. K. Hagemark and M. Broli, "Equilibrium Oxygen Pressures Over Solid Solutions of Urania-Yttria and Urania-Lanthana at $1100^{\circ}$ to $1400^{\circ} \mathrm{C}, "$ J. Am. Ceram. Soc. 50, 563-7 (1967). 
44. T. I. Markin and E. C. Crouch, "Thermodynamic Data for U-Ce-Oxides," J. Inorg. Nucl. Chem. 32, 77-82 (1970).

45. J. F. Wadier, "Phase Diagram and Thermodynamic Properties of" the Uranium-Neodymium-Oxygen System, " p. 59 in Centre d'Etudes Nucleaires de Fontenay-aux-Roses Tech. Rept. CEA-R-4507, November 1973.

46. J. Belle, "Oxygen and Uranium Diffusion in Uranium Dioxide (A Review)," J. Nucl. Mater. 30, 3-15 (1969). 
Appendix A. Coated Particle Characteristics 
Table A-I. Description of ORNL Fissile and Fertile Oxide Particles

\begin{tabular}{|c|c|c|c|c|c|c|c|}
\hline $\begin{array}{l}\text { Initial kernel } \\
\text { composition }\end{array}$ & $\begin{array}{l}\text { Batch } \\
\text { No. }\end{array}$ & $\begin{array}{l}\text { Kernel } \\
\text { diameter } \\
(\mu \mathrm{m})\end{array}$ & $\begin{array}{l}\text { Buffer } \\
\text { thickness } \\
(\mu \mathrm{m})\end{array}$ & $\begin{array}{l}\text { Inner LTI } \\
\text { thickness } \\
\quad(\mu \mathrm{m})\end{array}$ & $\begin{array}{c}\mathrm{SiC} \\
\text { thickness } \\
(\mu \mathrm{m})\end{array}$ & $\begin{array}{l}\text { Outer LTI } \\
\text { thickness } \\
\quad(\mu \mathrm{m})\end{array}$ & $\begin{array}{c}\text { In-Reactor } \\
\text { experiment } \\
\text { No. }\end{array}$ \\
\hline $\mathrm{UO}_{2}$ & OR-2089 H & 196 & 75 & 37 & 27 & 77 & $\begin{array}{ll}\text { HRB-7 } & \text { Rod } 6 \\
\text { HRB-8 } & \text { Rod } 6\end{array}$ \\
\hline $\mathrm{UO}_{2}-1 \% \mathrm{UC}_{2}$ & OR-2097 H & 194 & 68 & None & None & 78 & $\begin{array}{lll}\text { HRB-7 } & \text { Rod } 4 \\
\text { HRB-8 } & \text { Rod } 4\end{array}$ \\
\hline $\mathrm{UO}_{2}$ & OR-2124 H & 196 & 85 & None & None & 41 & $\begin{array}{ll}\text { HRB-7 } & \text { Rod } 7 \\
\text { HRB-8 } & \text { Rod } 7\end{array}$ \\
\hline $\mathrm{w}_{2}^{*}$ & PU-303 H & 227 & 85 & 35 & 27 & 41 & $\begin{array}{l}\text { HRB-7 Rod } 5 \\
\text { HRB-8 } \text { Rod } 5\end{array}$ \\
\hline${ }^{\mathrm{U}_{1}} 1.50^{\mathrm{N}} 0.38$ & $\mathrm{OR}-2098 \mathrm{H}$ & 193 & 71 & None & None & 76 & HRB-7 Rod 3 \\
\hline $\mathrm{ThO}_{2}{ }^{1.65^{\mathrm{N}}} 0.25$ & $\begin{array}{l}A 6590-55 P^{* *} \\
J-489\end{array}$ & $\begin{array}{l}497 \\
495\end{array}$ & $\begin{array}{l}29 \\
80\end{array}$ & $\begin{array}{l}\text { None } \\
\text { None }\end{array}$ & $\begin{array}{l}\text { None } \\
\text { None }\end{array}$ & $\begin{array}{l}53 \\
77\end{array}$ & $\begin{array}{l}\text { None }{ }^{t 7} \\
\text { None }\end{array}$ \\
\hline $\mathrm{ThO}_{2}$ & OR-1365 & 450 & 47 & None & None & 73 & $\begin{array}{ll}\text { H-I } & \text { Rod } 10 \\
\text { H-2 } & \text { Rod } 10 \\
\text { H-2 } & \text { Rod } 11\end{array}$ \\
\hline $\mathrm{ThO}_{2}$ & OR-1562 & 398 & 55 & None & None & 76 & $\begin{array}{l}\text { HRB-3 Rod 3A } \\
\text { None }\end{array}$ \\
\hline $\begin{array}{l}\text { Thno: } \\
\mathrm{ThO}_{2}\end{array}$ & $\begin{array}{l}\text { OR-1849 } \\
\text { OR-1856 }\end{array}$ & $\begin{array}{l}501 \\
488\end{array}$ & $\begin{array}{l}69 \\
88\end{array}$ & $\begin{array}{l}\text { None } \\
\text { Nonc }\end{array}$ & $\begin{array}{l}\text { None } \\
\text { None }\end{array}$ & $\begin{array}{l}77 \\
79\end{array}$ & HRB-4 Rod $3 \mathrm{~A}$ \\
\hline $\mathrm{Th}_{0.5^{2}} \mathrm{U}_{0.5^{\mathrm{O}}} 2$ & $\mathrm{OR}-2090 \mathrm{H}$ & 246 & 79 & None & None & 84 & $\begin{array}{l}\text { HRB-7 Rod } 12 \\
\text { HRB-8 } \\
\text { Rod } 12\end{array}$ \\
\hline $\operatorname{Th}_{0.67^{\mathrm{U}_{0}}} 0.33^{\mathrm{O}_{2}}$ & OR-2094 H & 282 & 85 & None & None & 89 & $\begin{array}{l}\text { HRB-7 Rod } 8 \\
\text { HRB-8 Rod } 8\end{array}$ \\
\hline${ }^{T h} 0.69^{U_{0}} 0.31^{\mathrm{O}_{2}}$ & PR-67 & 353 & 78 & None & None & 142 & $H-2-11$ \\
\hline $\mathrm{Th}_{0.80^{\mathrm{U}} 0.20^{\circ} 2}$ & $J-263$ & 354 & 101 & None & None & 92 & $\begin{array}{l}\text { HRB- } 7 \text { Rods } 2 \text { and } 1 \\
\text { HRB- } 8 \text { Rods } 2 \text { and } 1 \\
\text { OF-1 Rods } 1-1 \text {, } 2-? \\
3-r \text {, and } 4-1\end{array}$ \\
\hline$T_{0} 0.80^{U_{0}} 0.20^{\circ}$ ? & OR-1909 & 366 & 97 & None & None & 93 & HRB-6 Rod $3 B$ \\
\hline $\mathrm{Th}_{0.80^{\mathrm{U}}} 0.20^{\circ} 2$ & OR-2ll1 H & 360 & 95 & None & None & 95 & $\begin{array}{ll}\text { HRB-7 } & \text { Rod } 11 \\
\text { HRB-8 } & \text { Rod } 11\end{array}$ \\
\hline $\mathrm{Th}_{0} .80^{\mathrm{U}} 0.20^{\mathrm{U}_{2}}$ & $\mathrm{UR}-2.1 .16 \mathrm{II}$ & $36 n$ & 38 & 39 & 34 & 43 & HRB-7 Rod 9 \\
\hline${ }^{\mathrm{T}} 0.80^{\mathrm{U}} 0.20^{\circ} 2$ & PK-57 & 355 & 80 & None & None & 133 & $\begin{array}{lll}H 1-1 & \text { Rod } & 1 \\
H-1 & \text { Rod } & 10 \\
H-2 & \text { Rod } 10\end{array}$ \\
\hline $\mathrm{Th}_{0.80^{\mathrm{U}}} 0.20^{\circ}{ }^{*}$ & PU-2.91 & 351 & 105 & None & None & 55 & $\begin{array}{l}\text { HRB } 6 \text { Rud } 3 A \\
\text { OF-1 Rod } 5-3\end{array}$ \\
\hline $\operatorname{Th}_{0.89^{\mathrm{U}} 0.11^{\mathrm{O}} 2 .}$ & GGA-6155-00-02.0 ${ }^{\dagger}$ & $50 \pi$ & 106 & 32 & 34 & 42 & $\begin{array}{ll}\text { HRB-7 } & \text { Rod } 10 \\
\text { HRB-3 } & \text { Rod } 10\end{array}$ \\
\hline
\end{tabular}

$\sqrt{233_{\mathrm{U}} \text {. }}$

* Number of T. B. Lindemer's Laboratory notebook.

† Supplied by GAC.

thed in laboratory runs $14,18,20,24$, and 30 .

Sused in laboratory mun 32.

$5 \mathbf{5}$ Used in laboratory run 23. 
Table A-II. Descripion of GAC-Supplied Fissile and Fertile Carbide Particles

\begin{tabular}{|c|c|c|c|c|c|c|c|}
\hline $\begin{array}{l}\text { Initial kernel } \\
\text { composition }\end{array}$ & $\begin{array}{l}\text { Batch } \\
\text { No. }\end{array}$ & $\begin{array}{l}\text { Kernel } \\
\text { diameter } \\
(\mu \mathrm{m})\end{array}$ & $\begin{array}{l}\text { Biffer } \\
\text { thickness } \\
\quad(\mu \mathrm{m})\end{array}$ & $\begin{array}{c}\text { Inner ITI } \\
\text { thickness } \\
(\mu \mathrm{m})\end{array}$ & $\begin{array}{c}\text { SiC } \\
\text { thickness } \\
(\mu \mathrm{m})\end{array}$ & $\begin{array}{c}\text { Outer ITI } \\
\text { thickness } \\
(\mu \mathrm{m})\end{array}$ & $\begin{array}{l}\text { Laboratory } \\
\text { run } \\
\text { No. }\end{array}$ \\
\hline $\mathrm{UC}_{2}$ & $6151-00-035$ & 201 & 87 & 33 & 27 & 37 & 19 \\
\hline $\mathrm{UC}_{2}$ & A65990-58 $\mathrm{P}^{*}, * *$ & 454 & 85 & None & None & 43 & $\begin{array}{lll}11, & 12,13, & 14 \\
19, & 22, & 29, \\
32\end{array}$ \\
\hline $\mathrm{UC}_{0.28^{\mathrm{N}}} 0.72$ & A6590-46P $\mathrm{P}^{*}, * *$ & 420 & 18 & None & None & 48 & $22^{+t}$ \\
\hline $\mathrm{ThC}_{2}$ & $4000-225$ & 379 & 59 & None & None & 73 & I9A, 29 \\
\hline $\mathrm{ThC}_{2}$ & $4261-00-011$ & 358 & 54 & 35 & 25 & 38 & 33 \\
\hline $\mathrm{ThC}_{2}$ & $4413-127$ & 578 & 68 & None & None & 61 & 33 \\
\hline $\operatorname{Tr}: \mathrm{C}_{2}$ & $9 \mathrm{~T}-980-\mathrm{BL}$ & 371 & 52 & None & None & 65 & $18,33^{5}$ \\
\hline$T_{0.84} \mathrm{U}_{0.16^{\mathrm{C}}} 2$ & $\begin{array}{c}\text { Peach Bottom }{ }^{\top} \\
\text { Core-2 }\end{array}$ & 300,400 & 40,50 & None & None & 60,85 & $20^{8.8}$ \\
\hline
\end{tabular}

* Suppliea by ORNL.

* IJumber of T. B. Lindemer's laboratory notebook.

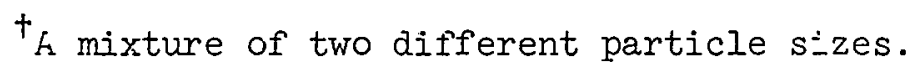

${ }^{+} t_{A l s o}$ used in in-reactor experiment HRB-10 Rod-18.

${ }^{\S} \mathrm{Als}$ o used in in-reactor experiment $\mathrm{H}-1$ Rod-9.

${ }_{5 \S} \mathrm{Als}$ used in in-reactor experiment El1-07 Compacts 16 and 18 . 
THIS PAGE

\section{WAS INTENTIONALLY \\ LEFT BLANK}


Appendix B. Original In-Reactor Data Used for KMC Calculations*

*Also see Reí. ¿é for previous data. 
IN-REACTOR SPECIMEN NUMBER HRB-7-4, UO2-1 1 UC2, (0R-2097H) $T(K)=1575-710 .(X * * 2-R I N * 2(1+2 L N(X / R$ IN) )

RATIO. FREE VOLUME/ OXIOE VOLUME= 1.96

INITIAL BURNUP. PERCENTFINA=0.0 DAYS $=134.0$

FINAL BUKNUP. PERCENT FIMA $=84.68 . R I N=C .16 C N$

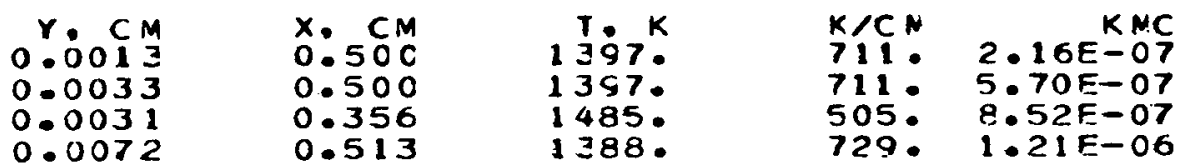

IN-REACTUR SPECIMEN NUMBER HRB-7-5, $233402,(P U-303+1)$

$T(K)=1600 .-735 \cdot(X * * 2-R I N * * 2(1+2 L N(X / R I N))$ )

RATIO. FREE VOLUME, OXIDE VGLLME=2.17

INITIAL BURNUP, PERCENT FINA= 0.0 DAYS $=184.0$

FINAL BURNUP. PERCENT FIMA=84.58.RIN=C.16CN

\begin{tabular}{|c|c|c|c|c|}
\hline $\begin{array}{r}Y . \quad C M \\
0.004 E \\
0.0020 \\
0.0065 \\
0.0020 \\
0.0050\end{array}$ & $\begin{array}{l}X . C M \\
0.523 \\
0.351 \\
0.312 \\
0.409 \\
0.409\end{array}$ & $\begin{array}{l}1 . K^{K} \\
1399^{\circ} \\
1510^{\circ} \\
1528 . \\
1477 . \\
1477^{\circ}\end{array}$ & $\begin{array}{l}K / C N \\
769 \\
5.15: \\
459= \\
601 . \\
601 .\end{array}$ & $\begin{array}{r}K N C \\
7.6 B E-07 \\
5.57 E-07 \\
2.08 E-06 \\
4.57 E-07 \\
1.14 E-06\end{array}$ \\
\hline
\end{tabular}

IN-REACTOR SPECIMEN NUMBER HRE-7-6, UO2, (OR-20B9H) $T(K)=1620 \ldots 760 .(x * * 2-R I N * * 2(I+2 L N(X) R I N))$

RATIO. FREE VOLUME, OXIDE VOLUME $=2.25$

INITIAL BURNUP. PERCENT FIMA=0.0 DAYS $=184.0$

FINAL BURNUP. PERCENT FIMA=84.54.RIN=0.16CM

$\begin{array}{rllll}Y . C M & X . C M & 1 . K & K / C N & K M C \\ 0.0050 & 0.356 & 1524 . & 541 . & 1.35 E-0.6 \\ 0.0037 & 0.488 & 1439 & 741 . & 6.59 E-07 \\ 0.0047 & 0.566 & 1376 . & 861 . & 6.50 E-07 \\ 0.0063 & 0.381 & 1510 . & 579 . & 1.56 F-06\end{array}$

IN-REACTOR SPEC IMEN NUMBER HRE-7-7, UO2, (OR-2114H)

$T(K)=1640-780 \cdot(X * 2-R I N * * 2(1+2 L N(X / R$ IN) )

RAT 10. FREE VOLUME, OXIDE VOLUME $=2.76$

INITIAL BURNUP. PERCENT FIMA=0.0 DAYS $=184.0$

FINAL BURNUP. PERCENT FIMA=84.57.RIN=0.16CM

\begin{tabular}{|c|c|c|c|c|}
\hline $\begin{array}{r}Y=0 M \\
0.0062 \\
0.0054 \\
0.0065 \\
0.0060 \\
0.0047 \\
0.0080 \\
0.0090\end{array}$ & $\begin{array}{l}X . \quad C M \\
0.533 \\
0.447 \\
0.414 \\
0.526 \\
0.508 \\
0.439 \\
0.405\end{array}$ & $\begin{array}{l}1 . K^{\prime} \\
1418^{\circ} \\
1484 . \\
1506^{\circ} \\
1424 . \\
1439^{\circ} \\
1489^{\circ}\end{array}$ & $\begin{array}{l}K / C M \\
832 . \\
697 . \\
646 . \\
820 . \\
792 . \\
685 .\end{array}$ & $\begin{array}{r}K N C \\
3 E-07 \\
7 E-06\end{array}$ \\
\hline
\end{tabular}

IN-REACTOR SPECIMEN NUMBER HRE-8-4, UO2-1 XUC2, (0R-2097H) $T(K)=1520-710-(X * 2-R I N * 2(1+2 L N(X / R I N))$

RATIO. FREE VOLUME, OXIDE VOLUME=1.96

INITIAL BURNUP. PERCENT FIMA= 0.0 DAYS $=228.0$

FINAL BURNUP, PERCENT FIMA $=84.81$, RIA $=0.16 \mathrm{CM}$

$\begin{array}{lllll}Y . C M & X . C M & T . K & K / C N \\ 0.0008 & 0.569 & 1290 . & 808 . & 7.84 E-08 \\ 0.0010 & 0.566 & 1292 . & 804 . & 1.05 E-07 \\ 0.0015 & 0.213 & 1488 . & 303 . & 5.56 E-07\end{array}$


IN-REACTOR SPECIMEN NUMBER HRQ U-5. 233UC? $(P U-303$ H)

$T(K)=1505 .-690 .(X * 2-R I N *$ S(I+2LN (X)RIA)i)

RATIO. FREE VOLUME. UXIDE VCLLME $=2.17$

INIYIAL BLIRUP. PEKCENT FINA=0.0 DAYS $=228.0$

FINAL BURNUP, PERCENT FIMA=84.63.RIA=C.I6CM

$\begin{array}{lllll}Y .1 C M & X . C M & T . K & K / C N & K N C \\ 0.0030 & 0.190 & 1480 . & 263 & 1.27 E-06 \\ 0.0082 & 0.432 & 1376 . & 596 . & 1.33 E-06\end{array}$

IN-REACTOR SPECIMFN NUMGFR HKB-3-6. UO?, (OR-POB9HI)

$T(K)=1495-670 \cdot(X * 2-R I N * \$ 2(1+2 L N(X / R(A))$

FATIO. FREE VOLUME/ OXIDE VOLLIME=2.25

INITI AL BLRNUP. PERCENT FIMA=0.0 DAYS= 228.0

FINAL BURNUP. PERCENT FIMA $=84.56, R I N=0.16 \mathrm{CN}$

$\begin{array}{lllll}Y . C M & X . C M & T . K & K / C M & K M C \\ 0.002 E & 0.552 & 1260 \% & 793 . & 2.80 E-07 \\ 0.0042 & 0.521 & 1313 . & 698 . & 5.33 F-07\end{array}$

IN-KEACTOR SHECIMEN NUMBER HFB-8-7, UC?, (OH-2114H) $T(K)=1515.6$ GJ. $(X * 2-R I N * 2(1+2 L N(X / R I N))$

RATIO. FREE VOLUME, OXIDE VOLLIMF:=2:76

INITIAL EURNUP, PERCENT FINA=0.0 DAYS $=228.0$

FINAL BURNUP. PERCENT FIMA=84.57, RIN $=0.16 \mathrm{CM}$

\begin{tabular}{|c|c|c|c|c|c|}
\hline $\begin{array}{r}Y .01 M \\
0.0105 \\
0.0050 \\
0.0090 \\
0.0087 \\
0.0075 \\
0.0060 \\
0.0082 \\
0.0100\end{array}$ & $\begin{array}{l}X . C M \\
0.551 \\
0.155 \\
0.216 \\
0.508 \\
0.330 \\
0.607 \\
0.554 \\
0.602\end{array}$ & $\begin{array}{l}11 . K \\
13050^{\circ} \\
14980^{\circ} \\
14830^{\circ} \\
13370^{\circ} \\
1440^{\circ} \\
1261 . \\
1271 . \\
12650^{\circ}\end{array}$ & ' & $\begin{array}{l}K / C N \\
761 . \\
214 . \\
298 . \\
7 C 1 . \\
456 . \\
838 . \\
820 . \\
931 .\end{array}$ & $\begin{array}{r}K N C \\
1.19 E-06 \\
2 . E 7 E-06 \\
3.37 E-06 \\
1 \cdot 13 F-06 \\
1.73 E-06 \\
5.78 E-07 \\
8.25 E-07 \\
\text {..79F-07 }\end{array}$ \\
\hline
\end{tabular}

HRH-4 FUEL SIC NUMBE? IA. THOZ

$T(K)=15(9 .-551 . \star x * 2,2) A Y E=\quad 244.0$

RATIU. FiRL VILUME /OXIBT VCLUAT- 0.78

INITIAL WUSHUP, REWCIENT FIMA= C.)

FINAL SUTNUF, PFRCFNT FIMA $=13.50$

\begin{tabular}{|c|c|c|c|c|}
\hline 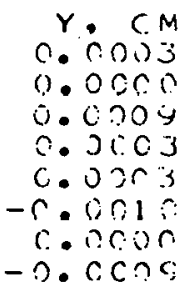 & 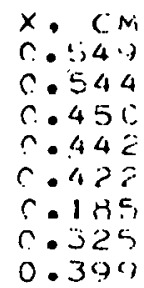 & 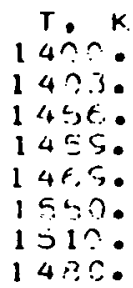 & 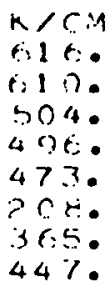 & 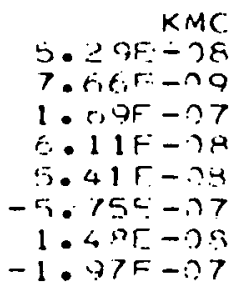 \\
\hline
\end{tabular}


IN-REACTOR SPECIMEN NUMBER HFE-7-12, (Tr.U) C2, (CR-20SOH) $T(K)=1700 .-810 .(X * * 2-R I N * * 2(1+2 L N(X / F I N)\})$

RATID. FREE VOLUME, OXIDE VOLUME $=1.71$

INITIAL BURNUP, PERCENT FINA=0.0 DAYS $=184.0$

FINAL BURNUP, PERCENT FIMA=46.32.RIN=0.16CN

\begin{tabular}{|c|c|c|c|c|}
\hline $\begin{array}{r}Y .0 C M \\
0.0014 \\
0.0001 \\
0.0064 \\
0.0015 \\
0.0007 \\
0.0021 \\
0.0035 \\
0.0025 \\
0.0042 \\
0.0020 \\
0.0039 \\
0.0018\end{array}$ & $\begin{array}{l}X .1 C M \\
0.264 \\
0.255 \\
0.566 \\
0.564 \\
0.259 \\
0.518 \\
0.630 \\
0.432 \\
0.554 \\
0.323 \\
0.577 \\
0.338\end{array}$ & $\begin{array}{l}1 . K^{\circ} \\
16440^{\circ} \\
16460^{\circ} \\
14400^{\circ} \\
1440^{\circ} \\
1640^{\circ} \\
14830^{\circ} \\
13790^{\circ} \\
15490^{\circ} \\
14520^{\circ} \\
16160^{\circ} \\
14310^{\circ} \\
1600^{\circ}\end{array}$ & 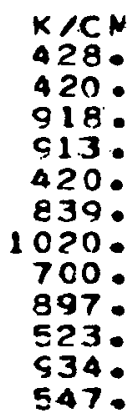 & $\begin{array}{l}K M C \\
5.56 E-07 \\
4.65 E-08 \\
9.10 E-07 \\
2.15 E-07 \\
2.64 E-07 \\
3.45 E-07 \\
4.10 E-07 \\
5 \cdot 39 E-07 \\
6.28 E-07 \\
6.28 E-07 \\
5.38 E-07 \\
5.50 E-07\end{array}$ \\
\hline
\end{tabular}

IN-REACTOR SPECIMEN NUMBER HRE-8-12, (TH.UIC2, (OF-2OSOH) $T(K)=1605-730 .(X * * 2-R I N * 2(1+2 L N(X / F I A))$

RATIO. FREE VOLUME/ OXIDE VOLUME = 1.71

INITIAL BURNUP, PERCENT FIMA=0.0 DAYS $=228.0$

FINAL BURNUP, PERCENT FIMA $=48.05 . R I N=C .16 \mathrm{CN}$

\begin{tabular}{|c|c|c|c|c|}
\hline $\begin{array}{r}Y . P M \\
0.0030 \\
0.0035 \\
0.0020 \\
0.0013 \\
0.0002 \\
0.0022 \\
0.0030 \\
0.0030 \\
0.0007 \\
0.000110 \\
0.0042 \\
0.00025 \\
0.0010 \\
0.00037\end{array}$ & $\begin{array}{l}X . C M \\
0.396 \\
0.424 \\
0.551 \\
0.351 \\
0.196 \\
0.231 \\
0.483 \\
0.483 \\
0.378 \\
0.272 \\
0.559 \\
0.577 \\
0.391 \\
0.429\end{array}$ & 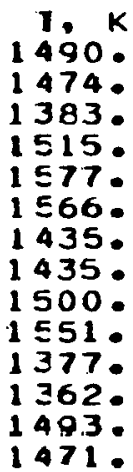 & 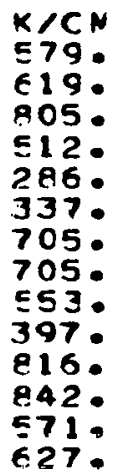 & $\begin{array}{r}K N C \\
5.85 E-07 \\
6.23 E-07 \\
2.41 E-07 \\
2.85 E-07 \\
1.11 E-07 \\
8.30 E-07 \\
4.45 E-07 \\
4.45 E-07 \\
1.55 E-C 7 \\
3.08 E-07 \\
5.01 E-07 \\
2.80 E-07 \\
1.9 B E-07 \\
6.57 E-07\end{array}$ \\
\hline
\end{tabular}

IN-REACTOR SPECIMEN NUMBER HRB-7-8. (2TH.U)O2. (OR-20S4H) $J(K)=1675-775 \cdot(X * * 2-R I N * 2(1+2 L N(X) R T A)$ )

RATIO. FREE VOLUME, OXIDE VOLUME=1.56

INITIAL BURNUP. PERCENT FIMA= 0.0 DAYS $=184.0$

FINAL BURNUP. PERCENT FIMA=33.53.RI $\mathrm{N}=0.16 \mathrm{CN}$

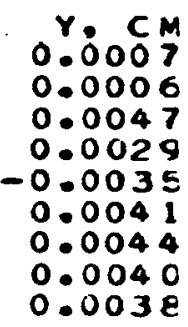

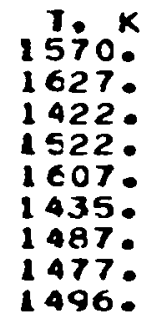

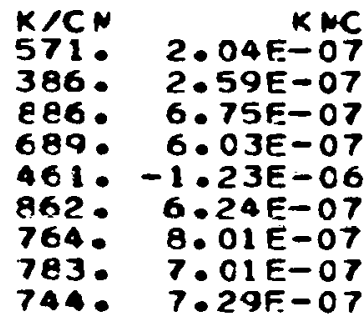


IN-FEACTOH SPECIMEN NUMBER HRB-8-8. (2TH,U)G2, (OR-20S4H) RAT

RATIO. FREE VULUME, OXIDE VOL LME= I. SE

INI I IAL BLRNUP, PERCENTFINA=0.0 DAYS $=228.0$

FINAL BURNUP. PERCENT FIMA $=35.83$.RIN $=0.16 \mathrm{CM}$

\begin{tabular}{|c|c|c|c|c|}
\hline $\begin{array}{r}Y .0 C M \\
0.0030 \\
0.0020 \\
0.0018 \\
0.0015 \\
0.0010 \\
0.0015 \\
0.0012 \\
0.0015 \\
0.0015 \\
0.0005 \\
0.0025\end{array}$ & $\begin{array}{l}X . C M \\
0.565 \\
0.561 \\
0.551 \\
0.541 \\
0.282 \\
0.564 \\
0.33 C \\
0.565 \\
0.564 \\
0.193 \\
0.50 C\end{array}$ & $\begin{array}{l}1.6 \\
1335^{\circ} \\
1341^{\circ} \\
1345^{\circ} \\
1357^{\circ} \\
1505^{\circ} \\
1335^{\circ} \\
1484{ }^{\circ} \\
13350^{\circ} \\
13390^{\circ} \\
1534 . \\
1386 .\end{array}$ & $\begin{array}{l}K / C N \\
791 . \\
7800^{\circ} \\
7660^{\circ} \\
752{ }^{\circ} \\
392 . \\
789 . \\
4590^{\circ} \\
791 . \\
784 . \\
2680^{\circ} \\
696 .\end{array}$ & $\begin{array}{l}\text { 3. } \\
3.43 E-07 \\
2.34 E-07 \\
2.11 E-07 \\
1.86 E-07 \\
2.93 E-07 \\
1.74 E-07 \\
3.05 E-07 \\
2.17 E-07 \\
1.74 E-07 \\
2.23 F-07 \\
3.51 E-07\end{array}$ \\
\hline
\end{tabular}

[N-REACTUR SPECIMEN NUMBER HRE-7-2. (4T+,U)O2.. (J-2EZ)

$T(K)=1553 .-673 \cdot(X * 2 * 2-R I N * 2(1+2 L N(X / R I N))$

KATIU, FKEE VCLUMF/ JXIDE VJLUME $=1.44$

INITIAL BURNUP. PERCIENT FIMA= 0.0 DAYS $=184.0$

FINAL BURNUP, NEKCENT FIMA=20.53.KIN=0.16CM

\begin{tabular}{|c|c|c|c|c|}
\hline $\begin{array}{r}Y .0 C M \\
0.00114 \\
0.0012 \\
0.0009 \\
0.0003 \\
0.0008 \\
-0.0002 \\
0.0010 \\
0.00025 \\
-0.0008\end{array}$ & $\begin{array}{l}X . C M \\
0.511 \\
0.320 \\
0.366 \\
0.250 \\
0.444 \\
0.14 .31 \\
0.251 \\
0.541 \\
0.20\end{array}$ & $\begin{array}{l}T . k \\
1333 . \\
1489 . \\
14403 . \\
1502 . \\
14425 . \\
1532 . \\
1515 . \\
1361 . \\
1529 .\end{array}$ & $\begin{array}{l}K / C M \\
687 . \\
431: \\
492: \\
390 . \\
598 . \\
267 . \\
339: \\
729 . \\
280 .\end{array}$ & $\begin{array}{r}K M C \\
2.45 E-07 \\
3.89 F-07 \\
2.49 E-07 \\
1.09 F-07 \\
1.71 E-07 \\
-1.11 E-07 \\
4.27 E-07 \\
4.00 F-07 \\
-4.20 F-07\end{array}$ \\
\hline
\end{tabular}

IN-KFACTOH SPFCI MEN NUMHER HRB-7-4. (4TH,U)O2, (UR-2116H) $T(K)=1633 .-\quad S O 5 \cdot(x * 2-R I N * * 2(1+2 L N(x / R$ IN ) ) KATIU, FKEE VOLUME' EXIDE VOLUMF= 1.34

INITIAL BURNUN, PERCFNT FIMA= 0.0 UAYS= 194.0

FINAL BURNUP, PFRCENT FIMA $=23.40 .2 I N=0.1$ KCM

\begin{tabular}{|c|c|c|c|c|}
\hline 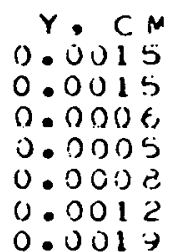 & $\begin{array}{l}x .8 N \\
0.3 .35 \\
0.510 \\
0.444 \\
0.49 .3 \\
0.371 \\
0 .+57 \\
0.34 .1\end{array}$ & $\begin{array}{l}1 . k . \\
1543 . \\
1464 . \\
1524 . \\
143.1 \\
147 \% . \\
1510 . \\
1441 .\end{array}$ & $\begin{array}{l}K / C M \\
547 . \\
939 . \\
716: \\
703 . \\
597 . \\
7.35: \\
993 .\end{array}$ & $\begin{array}{r}K M C \\
4.43 E-07 \\
2.45 E-07 \\
1.02 F-C 7 \\
7 \cdot 90 E-C 9 \\
1.95 E-07 \\
? \cdot 35 E-07 \\
2.91 E-07\end{array}$ \\
\hline
\end{tabular}

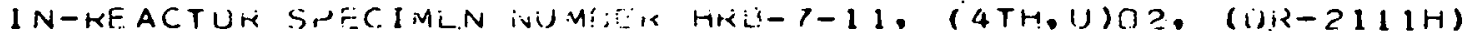
$T(K)=1695 .-320 \cdot(x * 2-k I N * 2(1+\operatorname{LiV}(x / R$ IN $))$ ) KATIU, FKEL VCLUME/ WX Ii)t. VUL.UIAE= 1 ? ?.8 INITIAL ISURNUP, DIECTENT FIMA=0.0 DAYS= 194.0

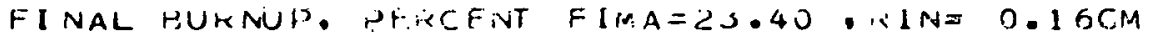

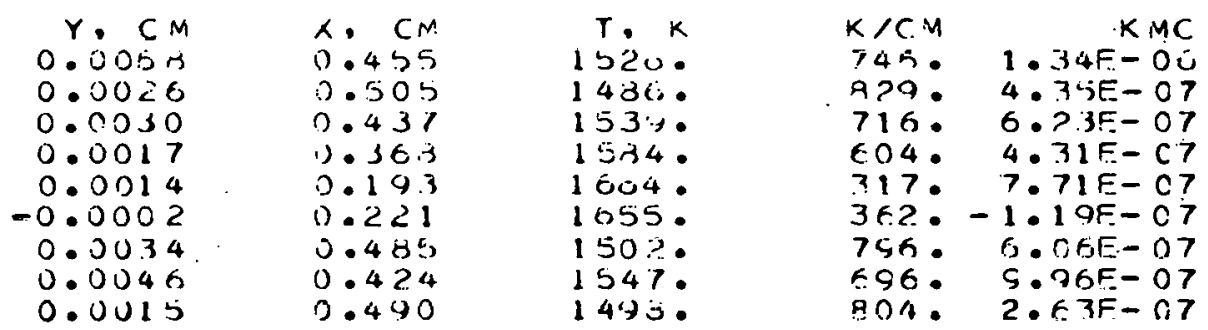


IN-REACTOK SPECIMEN NUMBER HRE-7-19, (4TH,U102, (J-263) $T(K)=1605 .-740 \cdot(X \star 2-R I N * 2(1+2 L N(X / R$ IN ) )

RATIO. FREE VOLUME/ OXIDE VOLUME $=1.44$

INITIAL BURNUP, PERCENT FIMA $=0.0$ DAYS $=184.0$

FINAL HURNUH. PFKCENT FIMA=19.95.RIN=0.1ECM

\begin{tabular}{|c|c|c|c|c|}
\hline $\begin{array}{r}Y .0 C N \\
0.00112 \\
0.00007 \\
0.00007 \\
0.00077 \\
0.0016 \\
0.00117 \\
0.00005 \\
0.0015 \\
0.00022\end{array}$ & $\begin{array}{l}X . \quad C M \\
0.559 \\
0.351 \\
0.559 \\
0.290 \\
0.452 \\
0.546 \\
0.290 \\
0.559 \\
0.478\end{array}$ & 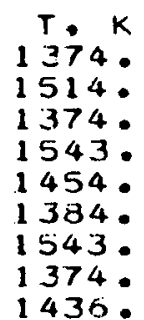 & $\begin{array}{l}K / C M \\
927 . \\
519: \\
827 . \\
429 . \\
669 . \\
808: \\
429: \\
827: \\
707 .\end{array}$ & $\begin{array}{r}K M C \\
1.72 E-07 \\
1.95 E-07 \\
1.01 E-07 \\
2.27 E-07 \\
3.28 E-07 \\
2.54 E-07 \\
1.75 E-07 \\
2.15 E-07 \\
4.04 E-07\end{array}$ \\
\hline
\end{tabular}

IN-REACTOR SPECIMEN NUMBER HRE-3-2, (4TH,U102, (J-263) $T(K)=1458-072 \cdot(X * 2-R I N * 2(1+2 L N(X / R$ IN $)))$

RATIO. FREE VOLUME, OXIDE VOLUME= 1.44

INI TIAL BURNUP, PERCENT FIMA= 0.0 DAYS $=228.0$

FINAL BURNUP, PERCENT FIMA=22.40, RIN=0.16CM

\begin{tabular}{|c|c|c|c|c|}
\hline $\begin{array}{r}Y .0 C M \\
0.0010 \\
0.0005 \\
0.0013 \\
0.0007 \\
0.0015 \\
0.0005 \\
0.0010 \\
0.0015 \\
0.0010 \\
0.0008 \\
0.0012 \\
0.0008 \\
-0.0002 \\
0.0010 \\
0.0000 \\
0.0007 \\
0.0020 \\
0.0015 \\
0.0005 \\
0.0005\end{array}$ & $\begin{array}{l}x . \\
0.5 M \\
0.587 \\
0.554 \\
0.561 \\
0.264 \\
0.508 \\
0.391 \\
0.554 \\
0.579 \\
0.523 \\
0.348 \\
0.417 \\
0.254 \\
0.201 \\
0.399 \\
0.196 \\
0.320 \\
0.444 \\
0.391 \\
0.295 \\
0.384\end{array}$ & 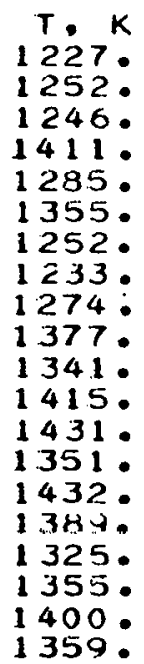 & 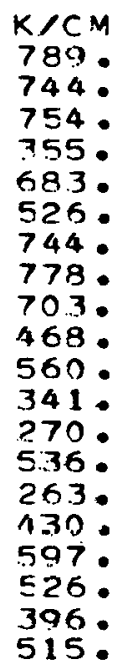 & $\begin{array}{r}K M C \\
9 \cdot 69 E-08 \\
5 \cdot 35 E-08 \\
1 \cdot 31 E-07 \\
1 \cdot 85 E-07 \\
1 \cdot 84 E-07 \\
8.87 E-08 \\
1 \cdot 07 E-07 \\
1 \cdot 49 E-07 \\
1 \cdot 17 E-07 \\
1 \cdot 54 E-07 \\
2 \cdot 04 E-07 \\
2 \cdot 2.3 E-07 \\
-9 \cdot 64 E-08 \\
1 \cdot 73 E-07 \\
4 \cdot 72 E-13 \\
1.71 E-07 \\
2.98 E-07 \\
2.66 E-07 \\
1 \cdot 26 E-07 \\
9.10 E-08\end{array}$ \\
\hline
\end{tabular}

IN-REACTOR SPECIMEN NUMBER HRB-8-11, (4TH,U)O2, (OR-2111H) $T(K)=1603 \cdot-740 \cdot(X * * 2-R I N * * 2(1+2 L N(X / R I N)))$

RATIO, FREE VOLUME/ UXIDE VOLUME= 1.28

INITIAL BURNUP, PERCENT FIMA= 0.0 DAYS $=228.0$

FINAL BURNUP. PERCENT FIMA=26.21,RIN=0.16CM

\begin{tabular}{|c|c|c|c|c|}
\hline $\begin{array}{r}Y .0 M \\
0.0025 \\
0.0027 \\
0.0010 \\
0.0037 \\
0.0025 \\
0.0015 \\
0.0025 \\
0.00220 \\
0.0013 \\
0.0018 \\
0.0020 \\
0.00022 \\
0.0025 \\
0.0015 \\
0.0027 \\
0.0022\end{array}$ & $\begin{array}{l}X .1 C M \\
0.554 \\
0.378 \\
0.432 \\
0.490 \\
0.516 \\
0.536 \\
0.422 \\
0.510 \\
0.368 \\
0.307 \\
0.353 \\
0.173 \\
0.452 \\
0.378 \\
0.450 \\
0.452\end{array}$ & 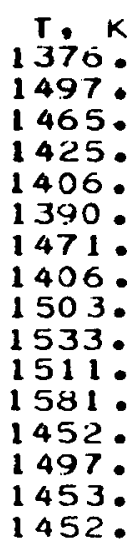 & $\begin{array}{l}K / C M \\
819 . \\
560 . \\
639 . \\
726 . \\
763 . \\
793 . \\
624 . \\
763 . \\
545 . \\
455 . \\
523 . \\
256 . \\
669 . \\
560 . \\
665 . \\
669 .\end{array}$ & $\begin{array}{r}K M C \\
2.93 F-07 \\
5.59 E-C 7 \\
1.70 E-07 \\
5 \cdot 33 F-07 \\
3.29 E-07 \\
1.86 E-07 \\
4.40 E-07 \\
2.63 F-07 \\
2.63 E-07 \\
4.59 E-07 \\
4.43 F-07 \\
1.24 E-07 \\
4.00 E-07 \\
3.05 E-07 \\
4.43 F-07 \\
3.60 F-07\end{array}$ \\
\hline
\end{tabular}




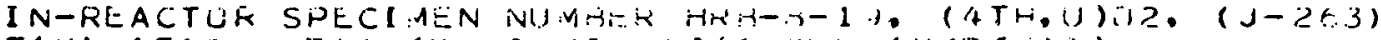

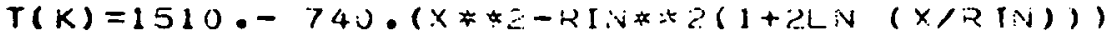

KATIO. FREE VGLUVIE, UX ID: VULlliN= 1.44

INITIAL HURNNUP, FIERC:NNT FIMA= 0.0 DAYS= ?.?.9.0

FINAL BURNUP. PEIRCENT FLMA=21.54, ININ=0.16CM

\begin{tabular}{|c|c|c|c|c|}
\hline 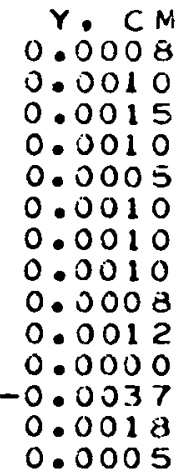 & $\begin{array}{l}x \cdot C . M \\
0.300 \\
0.340 \\
0.348 \\
0.305 \\
0.506 \\
0.554 \\
0.384 \\
0.536 \\
0.465 \\
0.500 \\
0.254 \\
0.414 \\
0.531 \\
0.554\end{array}$ & 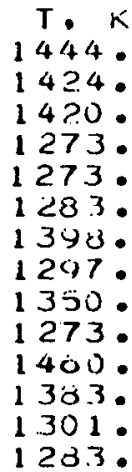 & $\begin{array}{l}K / C M \\
444 . \\
504 . \\
515 . \\
479 . \\
237 . \\
319 . \\
575 . \\
793 . \\
689 . \\
939 . \\
397 . \\
613 . \\
785 . \\
319 .\end{array}$ & 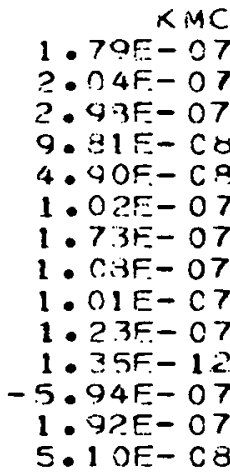 \\
\hline
\end{tabular}

IN-KEACTOR SPFCIMEN NUMBER I]F1-1-1. (4T1.U)02. (J-263) $T(K)=1423 .-310 . * * 2$. DAYS $=331.0$ RATIU. FREE VOLUME, UXIIIE VDLUME= 1.44

INITIAL BURNUP, PERCENTFIMA= 0.0

FINAL OUUNUP. PERCENT FIMA $=19.93$

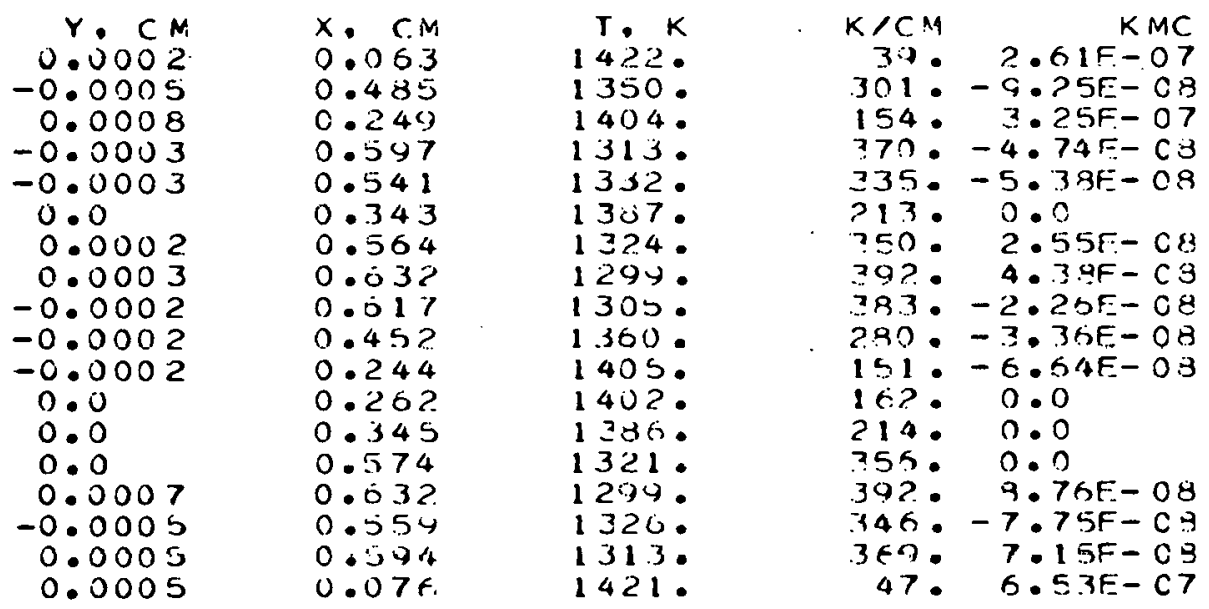

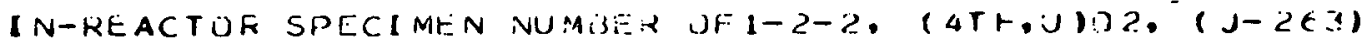
$T(K)=1423 .-310 . X * 2$. DAYS $=3.41 .0$ KATIO. FRFE VULUME /UX IDE VIIIUMF $=1.44$

INITIAL BURINUP. PFKCTNT F IMA= 0.0

FINAL BUTINUN. PFECENT FIMA.=1:3.44

\begin{tabular}{|c|c|c|c|c|}
\hline $\begin{array}{r}Y .0 C N \\
0.0007 \\
0.00013 \\
0.00010 \\
0.00012 \\
0.0012 \\
0.0013 \\
0.0017 \\
0.0012 \\
0.00110 \\
0.00018 \\
0.00017 \\
0.0003\end{array}$ & $\begin{array}{l}x .0 M \\
0.378 \\
0.505 \\
0.310 \\
0.056 \\
0.592 \\
0.531 \\
0.411 \\
0.478 \\
0.470 \\
0.521 \\
0.620 \\
0.175\end{array}$ & 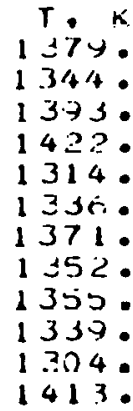 & $\begin{array}{r}\times 11 M \\
235 . \\
113: \\
103 . \\
75: \\
367: \\
329: \\
255: \\
296 . \\
291 . \\
321 . \\
384: \\
109 .\end{array}$ & $\begin{array}{r}K M C \\
1.65 F-07 \\
2.35 F-07 \\
3 . C .95-07 \\
2.57 F-C 7 \\
1.6 .3 F-07 \\
2.21 F-07 \\
3.75 F-C 7 \\
2.2 O F-C 7 \\
1.69 F-C 7 \\
1.41 F-07 \\
9.01 F-03 \\
1.87 F-C 7\end{array}$ \\
\hline
\end{tabular}


Continuation of $\mathrm{OF}-1-2-2$

\begin{tabular}{|c|c|c|c|c|}
\hline $\begin{array}{rl}0.0011 & 013 \\
0.0013 & 0.0002 \\
0.0007 \\
0.0007 \\
0.0003 \\
0.0008 \\
0.0013 \\
-0.0002 \\
0.0008 \\
0.00005 \\
0.0012 \\
0.0012 \\
-0.0002 \\
0.0012 \\
0.0012 \\
0.0007 \\
0.00110 \\
0.0007 \\
-0.0008 \\
0.0012 \\
0.0008 \\
0.0012 \\
0.0005 \\
0.0\end{array}$ & $\begin{array}{l}0.556 \\
0.180 \\
0.058 \\
0.505 \\
0.627 \\
0.500 \\
0.564 \\
0.594 \\
0.518 \\
0.140 \\
0.351 \\
0.394 \\
0.538 \\
0.556 \\
0.544 \\
0.589 \\
0.424 \\
0.274 \\
0.328 \\
0.544 \\
0.432 \\
0.424 \\
0.348 \\
0.190\end{array}$ & 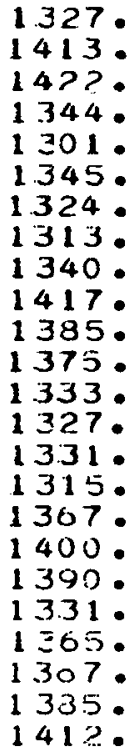 & 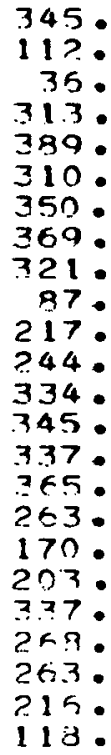 & $\begin{array}{r}1.56 F-07 \\
7.27 F-07 \\
2.94 F-07 \\
1.17 F-07 \\
4.43 E-08 \\
1.48 F-07 \\
2.04 E-C 7 \\
-2.39 E-08 \\
1.42 F-07 \\
3.54 E-C 7 \\
3.14 E-07 \\
2.76 F-C 7 \\
-2.71 E-08 \\
1.87 F-07 \\
1.87 F-07 \\
9.64 E-08 \\
2.17 E-C 7 \\
2.34 F-07 \\
-2.42 E-07 \\
1.37 F-C 7 \\
1.37 F-07 \\
7.53 F-C 7 \\
1.36 F-C 7 \\
0.0\end{array}$ \\
\hline
\end{tabular}

IN-REACTOR SPECIMEN NUMEER UF 1-3-2, (4TH,U102, ( J-263) $T(K)=1423 .-310 . * \times * 2$. DAYS $=381.0$

RATIO. FREE VOLUME /OXIDE VOLUME= 1.44

INITIAL BURNUF. PERCENT FIMA= 0.0

FINAL BURNUP. PERCENT FIMA=22.3Y

\begin{tabular}{|c|c|c|c|c|}
\hline $\begin{array}{ll}Y, & C M \\
0.000 & 05 \\
0.0 & \\
0.0000 & 0 \\
0.0000 & 0 \\
0.000 & 0 \\
0.00007 \\
0.00005 \\
0.0000 \\
0.0003 \\
0.0005 \\
0.00110\end{array}$ & $\begin{array}{l}X .1 C M \\
0.574 \\
0.597 \\
0.300 \\
0.236 \\
0.317 \\
0.505 \\
0.320 \\
0.394 \\
0.561 \\
0.531 \\
0.594\end{array}$ & 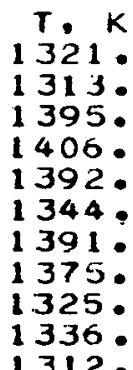 & $\begin{array}{l}K / C M \\
356 . \\
370 . \\
186 . \\
146 . \\
197 . \\
313 . \\
199 . \\
244 . \\
348 . \\
329 . \\
372 .\end{array}$ & $\begin{array}{r}K M C \\
7.4 \text { AF }-08 \\
0.0 \\
1 \cdot 02 E-12 \\
1: 31 E-12 \\
1.50 E-07 \\
1.17 E-07 \\
1.49 F-07 \\
7.52 E-13 \\
5.14 F-08 \\
8.27 E-08 \\
1.41 E-07\end{array}$ \\
\hline
\end{tabular}

IN-REACTOR SPECIMEN NUMBER OF 1-4-1, (4TH.U102, (J-263) $T(K)=1423 \cdot-310 * * x * 2$. DAYS $=381.0$

RATIO. FREE VOLUME/OXIDE VULUME= 1.44

INITIAL BURNUP. PERCENT FIMA= 0.0

FINAL BURNUP. PERCENT FIMA $=19.98$

\begin{tabular}{|c|c|c|c|c|}
\hline $\begin{array}{c}Y .0 C M \\
0.0003 \\
0.0005 \\
0.00117 \\
0.00110 \\
0.00022 \\
0.0008 \\
0.0040 \\
0.00110 \\
0.00110 \\
0.00023 \\
0.00005\end{array}$ & $\begin{array}{l}X .1 C M \\
0.597 \\
0.508 \\
0.531 \\
0.229 \\
0.414 \\
0.594 \\
0.493 \\
0.422 \\
0.429 \\
0.530 \\
0.503\end{array}$ & $\begin{array}{l}T . K \\
13130^{\circ} \\
13430^{\circ} \\
13360^{\circ} \\
1407 . \\
1370^{\circ} \\
13130^{\circ} \\
1340^{\circ} \\
1369^{\circ} \\
1366 . \\
1334 . \\
1345 .\end{array}$ & $\begin{array}{l}K / C M \\
370 . \\
315 . \\
329 . \\
142: \\
257: \\
369 . \\
306 . \\
261 . \\
266 . \\
332 . \\
312 .\end{array}$ & $\begin{array}{r}K M C \\
4.74 E-08 \\
8.74 E-C B \\
2.76 E-C 7 \\
4.26 F-C 7 \\
4.84 F-C 7 \\
1.19 E-07 \\
7.26 E-C 7 \\
2.19 E-07 \\
2.14 F-07 \\
3.81 E-07 \\
8.85 F-C 8\end{array}$ \\
\hline
\end{tabular}


IN-REACTOR SPECI NIEN NUMBER UF1-5-3, (4TH, 233U)02, (PU-291)

$T(K)=1423.310 . X * 2$, DAYS $=331.0$

RATIU. FREE VOLUMF, JXIIDE VDLUIAE= 1.44

INITIAL BURNUP. PERCIENT FIMA= 0.0

FINAL BUR̈NUP, PERCFNT FIMA=22.08B

\begin{tabular}{|c|c|c|c|c|}
\hline 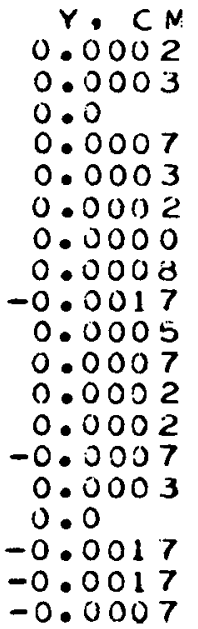 & $\begin{array}{l}X . C M \\
0.498 \\
0.564 \\
0.434 \\
0.582 \\
0.424 \\
0.546 \\
0.437 \\
0.521 \\
0.584 \\
0.315 \\
0.378 \\
0.554 \\
0.155 \\
0.241 \\
0.221 \\
0.249 \\
0.505 \\
0.582 \\
0.582\end{array}$ & 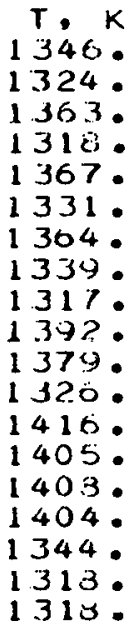 & $\begin{array}{l}K / C M \\
309 . \\
350 . \\
272 . \\
361: \\
267 . \\
339 . \\
271 . \\
323 . \\
362 . \\
105 . \\
235 . \\
346 . \\
96 . \\
150 . \\
137 . \\
154 . \\
313 . \\
361 . \\
361 .\end{array}$ & $\begin{array}{r}K M C \\
2.99 E-08 \\
5.11 \mathrm{E}-08 \\
0.0 \\
9.91 \mathrm{E}-\mathrm{C8} \\
7.23 \mathrm{E}-08 \\
2.66 \mathrm{E}-08 \\
6.66 \mathrm{E}-1.3 \\
1.41 \mathrm{E}-07 \\
-2.44 E-07 \\
1.52 E-07 \\
1.65 \mathrm{~F}-07 \\
2.58 \mathrm{E}-08 \\
1.06 \mathrm{E}-07 \\
-2.69 \mathrm{E}-07 \\
1.47 \mathrm{E}-07 \\
0.0 \\
-2.93 \mathrm{E}-07 \\
-2.45 \mathrm{~F}-07 \\
-9.81 \mathrm{E}-\mathrm{CB}\end{array}$ \\
\hline
\end{tabular}

IN-KEACTOR SPECIMEN NUMBER HKB-7-10. (ATH.U)C2. (GGA-6155-00-020) $T(K)=1695-800 .(X * 2-K I N * 2(1+2 L N(X / R(N)))$

HAT IU. FREE VOLUME, UXIDE VCLLME= 0.94

INITIAL GURNUP. PERCENTFIMA= 0.0 DAYS $=184.0$

FINAL BURNUP, PERCENT FIMA=17.84.RIN=C.16CM

\begin{tabular}{|c|c|c|c|c|}
\hline $\begin{array}{r}Y .0 C M \\
0.001 E \\
0.0016 \\
0.0038 \\
0.002 C \\
-0.0002 \\
0.0015 \\
0.0005\end{array}$ & $\begin{array}{l}X . \quad C M \\
0.345 \\
0.345 \\
0.495 \\
0.396 \\
0.343 \\
0.437 \\
0.305\end{array}$ & 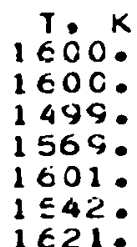 & $\begin{array}{l}K / C N \\
5530^{\circ} \\
5530^{\circ} \\
792^{\circ} \\
634 . \\
5490^{\circ} \\
699^{\circ} \\
489^{\circ}\end{array}$ & $\begin{array}{r}K N C \\
3.64 E-07 \\
4.66 E-07 \\
6.69 E-07 \\
4.89 E-07 \\
-7.35 E-08 \\
4.07 E-07 \\
1.69 F-07\end{array}$ \\
\hline
\end{tabular}

IN-KEACTOR SPECIMEN NUMBER HRÄ8-10. (8TH:L)02. (GGA-6155-00-020) $T(K)=1600$ - 725 . $(X * 2-R I N * \$ 2(1+2 L N$ (X)RIAI)

KATIU. FREE VOLUME/ OXIDE VGLUME $=0.94$

INITIAL BUKNUP. PERCENT FINA= 0.0 DAYS= ? 2.0 .0

FINAL BUKNUP. SERCENT FIMA=20.9E.RIA $=0.16 \mathrm{CM}$

\begin{tabular}{|c|c|c|c|c|}
\hline $\begin{array}{l}Y .0 C M \\
0.0035 \\
0.0065 \\
0.0020 \\
0.0023 \\
0.0015 \\
0.0002 \\
0.0025 \\
0.0025 \\
0.0017 \\
0.0011\end{array}$ & $\begin{array}{l}X . C M \\
0.54 G \\
0.554 \\
0.5 C C \\
0.406 \\
0.546 \\
0.422 \\
0.282 \\
0.356 \\
0.536 \\
0.190\end{array}$ & $\begin{array}{l}1 . K^{1} \\
1382 . \\
1378 . \\
1418 . \\
1480 . \\
1384 . \\
1471 . \\
1542^{\circ} \\
1486 . \\
1390 . \\
1574 .\end{array}$ & $\begin{array}{l}K 1 C N \\
796 . \\
802 . \\
726 . \\
589 . \\
792 . \\
611 . \\
409 . \\
575 . \\
781 . \\
276 .\end{array}$ & $\begin{array}{r}K M C \\
4 \cdot 26 E-07 \\
7.8 N F-07 \\
2.82 F-07 \\
4.25 F-07 \\
1 \cdot 84 E-07 \\
1 \cdot 12 E-C 6 \\
7.39 F-07 \\
4.88 E-07 \\
2.20 E-07 \\
4.55 E-07\end{array}$ \\
\hline
\end{tabular}


PB DRIVER E11-07. CUMPACT 16.5.25/1 (TH.U)C2.701 CAYS $T(K)=1588-\quad 30 .(X \$ 2-R I N \$ 2(1+2 L N(X / R I A)))$ RATIO, FREE VOLUME, OXIDE VOLUME $=1.74$

INITIAL BURNUP, PERCENTFINA $=0.0$ DAYS $=701.0$

FINAL BUTANU, PEREENT FIMA=8.95.RINE ?.PPCN

\begin{tabular}{|c|c|c|c|c|}
\hline $\begin{array}{r}Y .0 C M \\
0.0014 \\
0.0008 \\
0.0003 \\
0.0015 \\
0.0013 \\
0.0007 \\
0.0014 \\
-0.0001 \\
0.0014 \\
0.0006 \\
0.0 \\
0.0004 \\
0.0007 \\
0.0018 \\
-0.0000 \\
0.0003 \\
0.0032 \\
0.0027 \\
0.0026 \\
0.0014 \\
0.0032 \\
0.0005 \\
0.0019 \\
0.001 \\
-0.0007 \\
0.0015 \\
0.0008 \\
0.0015 \\
0.0042 \\
0.0009 \\
0.0011 \\
0.0001 \\
-0.0004 \\
0.0012 \\
0.0013 \\
0.0013 \\
0.0010 \\
0.0013 \\
0.0008 \\
0.0006 \\
0.0013 \\
0.0003 \\
0.0006 \\
0.0006 \\
-0.0013 \\
0.0016 \\
0.0014 \\
0.0000 \\
0.0038 \\
0.0031 \\
0.0031 \\
-0.0002 \\
0.0027 \\
0.0010 \\
0.0003\end{array}$ & $\begin{array}{l}x .1 C M \\
2.255 \\
2.490 \\
2.304 \\
2.304 \\
2.362 \\
2.403 \\
2.428 \\
2.460 \\
2.442 \\
2.510 \\
2.362 \\
2.308 \\
2.252 \\
2.244 \\
2.582 \\
2.675 \\
2.700 \\
2.620 \\
2.637 \\
2.655 \\
2.552 \\
2.539 \\
3.416 \\
2.442 \\
2.525 \\
2.392 \\
2.351 \\
3.415 \\
2.561 \\
2.643 \\
2.655 \\
2.674 \\
2.623 \\
3.286 \\
2.777 \\
2.908 \\
2.930 \\
3.320 \\
2.854 \\
2.821 \\
2.763 \\
2.834 \\
2.932 \\
2.959 \\
2.893 \\
2.927 \\
2.951 \\
2.905 \\
2.959 \\
3.028 \\
3.090 \\
3.171 \\
3.112 \\
3.140 \\
3.285\end{array}$ & 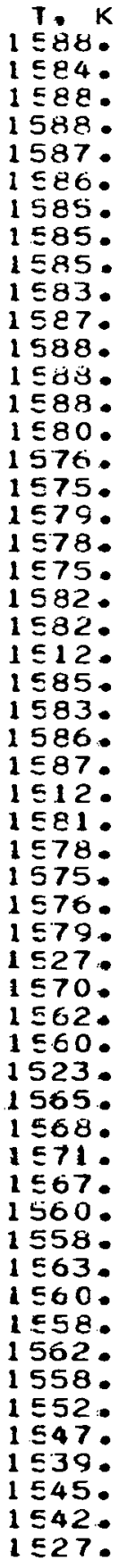 & 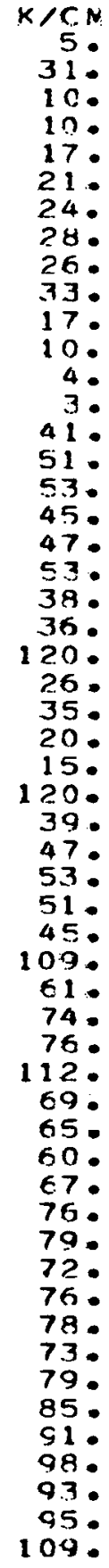 & 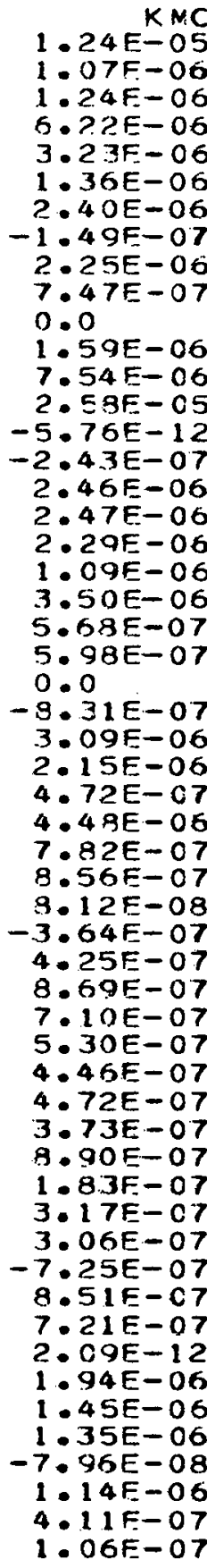 \\
\hline
\end{tabular}


Continuation of PB Driver Ell-07, Compact 16

\begin{tabular}{|c|c|c|c|c|}
\hline $\begin{array}{r}-0.0005 \\
-0.0001 \\
-0.0001 \\
0.0008 \\
0.0032 \\
0.0008 \\
-0.0007 \\
0.0024 \\
-0.0002 \\
0.00118 \\
0.00228 \\
0.0004 \\
0.00111 \\
0.00113 \\
0.0012 \\
0.00110 \\
-0.0001\end{array}$ & $\begin{array}{l}3.038 \\
3.051 \\
3.032 \\
3.195 \\
3.202 \\
3.223 \\
3.173 \\
3.320 \\
3.150 \\
3.244 \\
3.2280 \\
3.255 \\
3.259 \\
3.316 \\
3.347 \\
3.344 \\
3.416\end{array}$ & 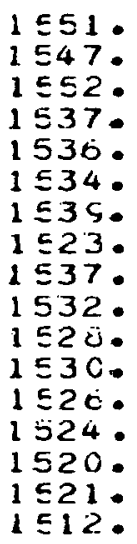 & 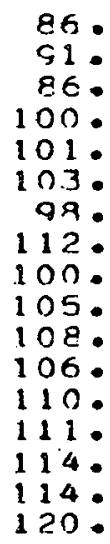 & $\begin{array}{r}-2.31 E-07 \\
-4.34 E-08 \\
-4.65 E-08 \\
3.10 E-07 \\
1.23 E-06 \\
3.03 E-07 \\
-2.73 E-07 \\
8.24 E-07 \\
-7.80 E-08 \\
5.65 E-07 \\
7.94 E-07 \\
1.46 E-07 \\
3.86 E-07 \\
4.43 E-07 \\
6.03 E-07 \\
3.36 E-07 \\
-2.70 E-12\end{array}$ \\
\hline
\end{tabular}

PB DKIVER E11-07, CUMPACT 18, 5.25/1 (TH.U)C2.701 CAYS $T(K)=1574 .-29 \cdot(x * 2-R I N * 2(1+2 L N(x / R I N))$ RATIOI, FREE VOLUME/ OXIDE VOLLME= 1.74

INITIAL BLRNUP. PERCENT FIMA $=0.0$ DAYS $=701.0$

FINAL BURNUP. PERCENT FIMA $=8.53$. RI $N=2.22 \mathrm{CM}$

\begin{tabular}{|c|c|c|c|c|}
\hline $\begin{array}{r}Y .0 M \\
0.0024 \\
-0.0009 \\
0.0004 \\
0.0017 \\
0.0010 \\
0.0012 \\
0.0 \\
0.0002 \\
0.0008 \\
-0.0006 \\
0.0008 \\
0.0008 \\
0.0018 \\
0.0010 \\
-0.0003 \\
0.0004 \\
0.0011 \\
0.0005 \\
0.0039 \\
0.0029 \\
0.0007 \\
0.0007 \\
0.0000 \\
0.0025 \\
0.0017 \\
-0.0008 \\
0.0001 \\
0.0020 \\
0.0012 \\
0.0007 \\
-0.0003 \\
0.0003 \\
0.0015 \\
0.0013\end{array}$ & 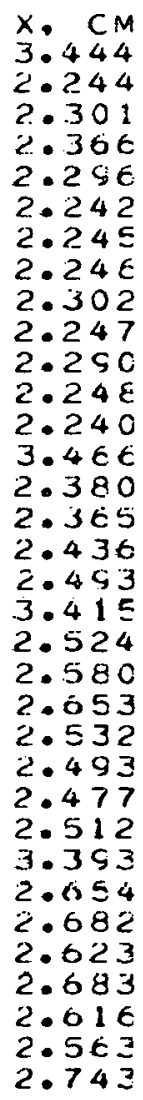 & 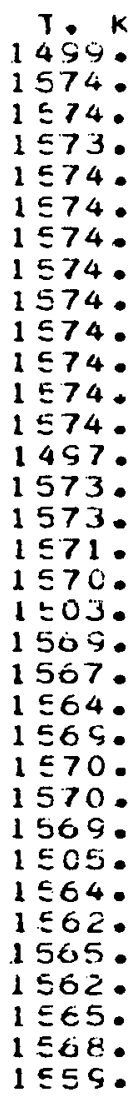 & 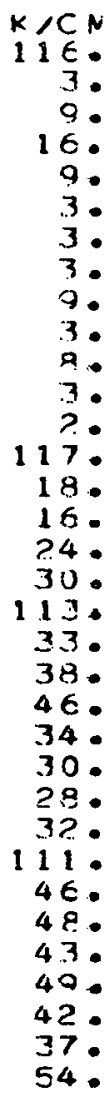 & 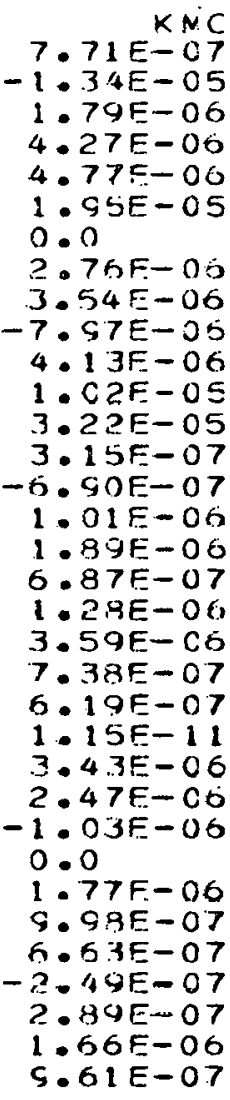 \\
\hline
\end{tabular}


Continuation of PB Driver Ell-07, Compact 18

\begin{tabular}{|c|c|c|c|c|}
\hline $\begin{array}{l}0.0016 \\
0.0004 \\
0.0011 \\
0.0010 \\
0.0009 \\
0.0031 \\
0.0041 \\
0.0002 \\
0.0008 \\
0.0026 \\
0.0025 \\
0.0018 \\
0.0028 \\
0.0024 \\
0.0011 \\
0.0031 \\
0.0022 \\
0.0025 \\
0.0005 \\
0.0038 \\
0.0032 \\
0.0025 \\
0.0011 \\
0.0028 \\
0.00012 \\
0.0027 \\
0.0011 \\
0.0019 \\
0.0035 \\
0.0016 \\
0.0027 \\
0.0022 \\
0.0018 \\
0.0015\end{array}$ & $\begin{array}{l}2.753 \\
2.800 \\
2.854 \\
3.345 \\
2.738 \\
2.755 \\
2.848 \\
2.812 \\
2.980 \\
3.053 \\
3.092 \\
3.323 \\
3.043 \\
3.022 \\
3.193 \\
3.010 \\
2.900 \\
2.933 \\
3.154 \\
3.087 \\
3.225 \\
3.091 \\
3.088 \\
3.142 \\
3.268 \\
2.969 \\
3.024 \\
3.168 \\
3.162 \\
3.352 \\
3.153 \\
3.322 \\
3.448 \\
3.470\end{array}$ & 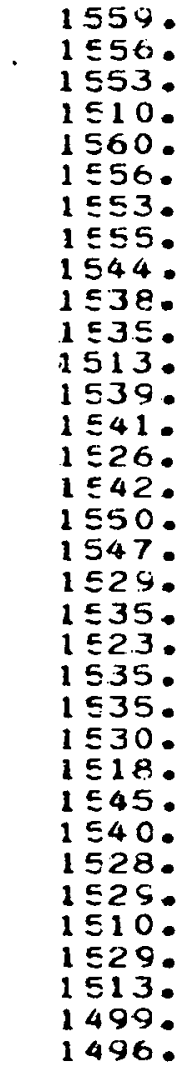 & 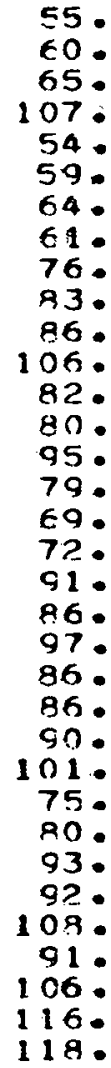 & 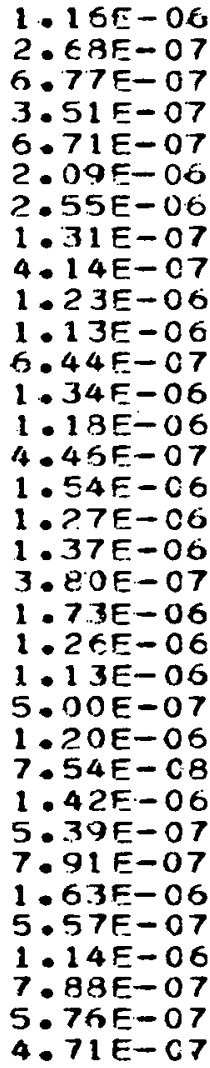 \\
\hline
\end{tabular}




\author{
ORNL/TM-5207 \\ UC-77 - Gas Cooled Reactor Technology
}

\title{
INTERNAL DISTRIBUTION
}

1. E. J.Allen

2. R. L. Beatty

3. R. A. Bradley

4. A. J. Caputo

5. T. E. Cole

6. J. A. Conlin

7. J. H. Coobs

8. D. A. Costanzo

9. F. F. Dyer

10. W. P. Eatherly

11. R. B. Evans III

12. J. I. Federer

13. D. E. Ferguson

14. P. A. Hass

15. R. L. Hamner

16. F. E. Harrington

17. C. C. Haws

18. F. J. Homan

19. J. D. Jenkins

20. D. R. Johnson

21. M. J. Kania

22-59. P. R. Kasten

60. H. T. Kerr

61. W. J. Lackey

62-69. T. B. Lindemer

70. E. L. Long, Jr.

71. A. I. Lotts

72. A. P. Malinauskas

73. B. H. Montgomery

74. C. S. Morgan

75. M. T. Morgan

76. F. H. Neill

77. K. J. Notz
78. A. R. Olsen

79. H. Postma

80-87. R. L. Pearson

88. W. H. Pechin

89. R. H. Rainey

90. J M Robbins

91. J. P. Sanders

92. Dunlap Scott

93. J. D. Sease

94. J. H. Shaffer

95. R. I. Shepard

96. J. W. Snider

97. V. J. Tennery

98. T. N. Tiegs

99. D. B. Trauger

100. J. E. Van Cleve

101. K. H. Valentine

102. V. C. A. Vaughen

103. T. N. Washburn

104. G. W. Weber

105. J. R. Weir

106. R. P. Wichner

107. R. G. Wymer

108-109. Central Research Library

110. Document Reference Section

111. Laboratory Records, ORNL-RC

112-121. Laboratory Records

122. Ken Davis (consultant)

123. J. C. Frye (consultant)

124. C. II. Icc (concultant)

125. J. J. Katz (consultant)

126. R. B. Richards (consultant)

\section{EXTERNAL DISTRIBUTION}

127. Research and Technical Support Division, ERDA-ORO, P. O. Box E, Oak Ridge, Tn. 37830

128. Director, Reactor Division, ERDA-ORO, P. O. BOx E, Oak Ridge, Tn. 37830

129-130. Director, Division of Nuclear Fuel Cycle and Production, ERDA, Washington, D.C. 20545

131-132. Director, Division of Reactor Research and Development, ERDA, Washington, D.C. 20545

133-299. Given distribution as shown in TID-4500 under category UC-77Gas-Cooled Reactor Technology 